\title{
Pharmaceutical Prospects of Bee Products: Special Focus on Anticancer, Antibacterial, Antiviral, and Antiparasitic Properties
}

\author{
Firzan Nainu ${ }^{1, * \mathbb{C}}$, Ayu Masyita ${ }^{1}$, Muh. Akbar Bahar ${ }^{1} \mathbb{D}$, Muhammad Raihan ${ }^{1}$, Shajuthi Rahman Prova ${ }^{2}$, \\ Saikat Mitra ${ }^{2}$, Talha Bin Emran ${ }^{3, *(\mathbb{D})}$ and Jesus Simal-Gandara ${ }^{4, *(\mathbb{D})}$ \\ 1 Faculty of Pharmacy, Hasanuddin University, Makassar 90245, Sulawesi Selatan, Indonesia; \\ masyitaa18c@student.unhas.ac.id (A.M.); akbarbahar@unhas.ac.id (M.A.B.); mraihan@unhas.ac.id (M.R.) \\ 2 Department of Pharmacy, Faculty of Pharmacy, University of Dhaka, Dhaka 1000, Bangladesh; \\ shajutirahman19@gmail.com (S.R.P.); saikatmitradu@gmail.com (S.M.) \\ 3 Department of Pharmacy, BGC Trust University Bangladesh, Chittagong 4381, Bangladesh \\ 4 Nutrition and Bromatology Group, Department of Analytical and Food Chemistry, Faculty of Food Science \\ and Technology, University of Vigo, Ourense Campus, E32004 Ourense, Spain \\ * Correspondence: firzannainu@unhas.ac.id (F.N.); talhabmb@bgctub.ac.bd (T.B.E.); jsimal@uvigo.es (J.S.-G.); \\ Tel.: +62-821-9131-0384 (F.N.); +88-01819-942214 (T.B.E.); +34-988-387-001 (J.S.-G.)
}

Citation: Nainu, F.; Masyita, A.; Bahar, M..A.; Raihan, M.; Prova, S.R.; Mitra, S.; Emran, T.B.; Simal-Gandara, J. Pharmaceutical Prospects of Bee Products: Special Focus on

Anticancer, Antibacterial, Antiviral, and Antiparasitic Properties. Antibiotics 2021, 10, 822. https:// doi.org/10.3390/antibiotics10070822

Academic Editors: Marina Spînu,

Magdalena Rzewuska and

Emoke Pall

Received: 2 June 2021

Accepted: 2 July 2021

Published: 6 July 2021

Publisher's Note: MDPI stays neutral with regard to jurisdictional claims in published maps and institutional affiliations.

Copyright: (c) 2021 by the authors. Licensee MDPI, Basel, Switzerland. This article is an open access article distributed under the terms and conditions of the Creative Commons Attribution (CC BY) license (https:/ / creativecommons.org/licenses/by/ $4.0 /)$.

\begin{abstract}
Bee products have long been used in traditional healing practices to treat many types of disorders, including cancer and microbial-related diseases. Indeed, several chemical compounds found in bee products have been demonstrated to display anticancer, antibacterial, antiviral, and antiparasitic properties. With the improvement of research tools and in view of recent advances related to bee products, this review aims to provide broad yet detailed insight into the pharmaceutical prospects of bee products such as honey, propolis, bee pollen, royal jelly, bee bread, beeswax, and bee venom, in the domain of cancer and infectious disease management. Available literature confirms the efficacy of these bee products in the alleviation of cancer progression, inhibition of bacterial and viral proliferation, and mitigation of parasitic-related symptoms. With such potentials, bioactive components isolated from the bee products can be used as an alternative approach in the long-run effort to improve humans' health at a personal and community level.
\end{abstract}

Keywords: honeybee products; anticancer; antibacterial; antiviral; antiparasitic

\section{Introduction}

Biologically active bee products are being popular in the current world due to their promising health benefits. The use of honey for nutritional and medicinal purposes dates back nearly 5500 years [1]. Hand collecting honeybees was a significant traditional practice in ancient populations as it was the individual method to get honey, which is still being practiced currently by some people in forest areas [2]. To date, several honeybee products such as honey, bee pollen, royal jelly, propolis, beeswax, bee bread, and bee venom have been identified as prospective sources of compounds with therapeutical potentials in the management of cancer and infections by different types of bacteria, viruses, and parasites [3].

Cancer is one of the major maladies affecting humankind and remains one of the leading causes of death worldwide [4]. Honey, pollen, bee venom, royal jelly, and propolis are commonly used in apitherapy to treat various cancers. Several research studies have reported that bee products are promising candidates for cancer treatment [5-7]. Studies have confirmed that honey is an oxidizing agent with pro-apoptotic, anti-proliferative, anti-metastatic, immune-modulatory, and anti-inflammatory properties [6]. Bee venom is a biotoxin or apitoxin synthesized and secreted by a gland in the bee's abdominal cavity. It appears to be effective in the management of cancer, including the induction of cytotoxicity, 
necrosis, apoptosis, and proliferation inhibition in various cancer cells, including liver, breast, lung, prostate, and bladder cancer cells [7].

Honey is one of the most versatile bee products that possesses a wide range of properties and applications. It is prepared by bees from honeydew and nectar [8]. It contains several bioactive components that differ based on the type of bee and environmental conditions under which it was collected [9]. Honey works as an anti-inflammatory, antioxidant, anti-bacterial agent, etc., and improves the adherence of skin grafts and the facilitates the wound healing process [9]. Propolis, also known as bee glue, is collected by bees from shrubs, tree buds, as well as green plants [3]. It is made up of essential oils, resins, pollen, waxes, and numerous organic compounds, such as amino acids, polyphenols, minerals, flavonoids, ethanol, vitamin E, vitamin B complex, and vitamin A. It works against hive-invading bacteria, viruses, and other pathogenic microorganisms [10].

Bee products (Figure 1) are also well-recognized due to their antiviral activities, which can outperform standard drugs in some cases. Clinical data suggested that an ointment containing Canadian propolis outperformed placebo or acyclovir in the treatment of genital herpes simplex [3]. Propolis can also inhibit the replication of hepatitis $C$ virus in vitro, inhibit HIV-1 activity by acting on viral integrase, and propolis containing caffeic acid derivatives is potent against herpes simplex 1 and 2 [11,12]. In addition, honey and propolis have also been reported to yield antiviral activities against some human pathogenic viruses such as influenza virus [13], respiratory syncytial virus (RSV) [14], human herpesviruses [15], influenza virus [16-18], HIV [19], human T-cell leukemialymphoma virus type 1 (HLTV-1) [20], Newcastle disease virus (NDV) [21], RSV [22], poliovirus (PV)-type 1 [23], and dengue virus (DENV) [24]. Other bee products such as bee pollen and bee bread have been shown to be effective as antivirals in an in vitro setting against herpes simplex virus (HSV)-1 and HSV-2 [25] and was moderately active against influenza viruses (strains of H1N1, H3N2, and H5N1) [26]. With their antiviral potentials, bee products such as honey and propolis, have been recently tested in the clinical trials against SARS-CoV-2, an emerging human viral pathogen that has been suggested to cause coronavirus disease (COVID)-19 [27].

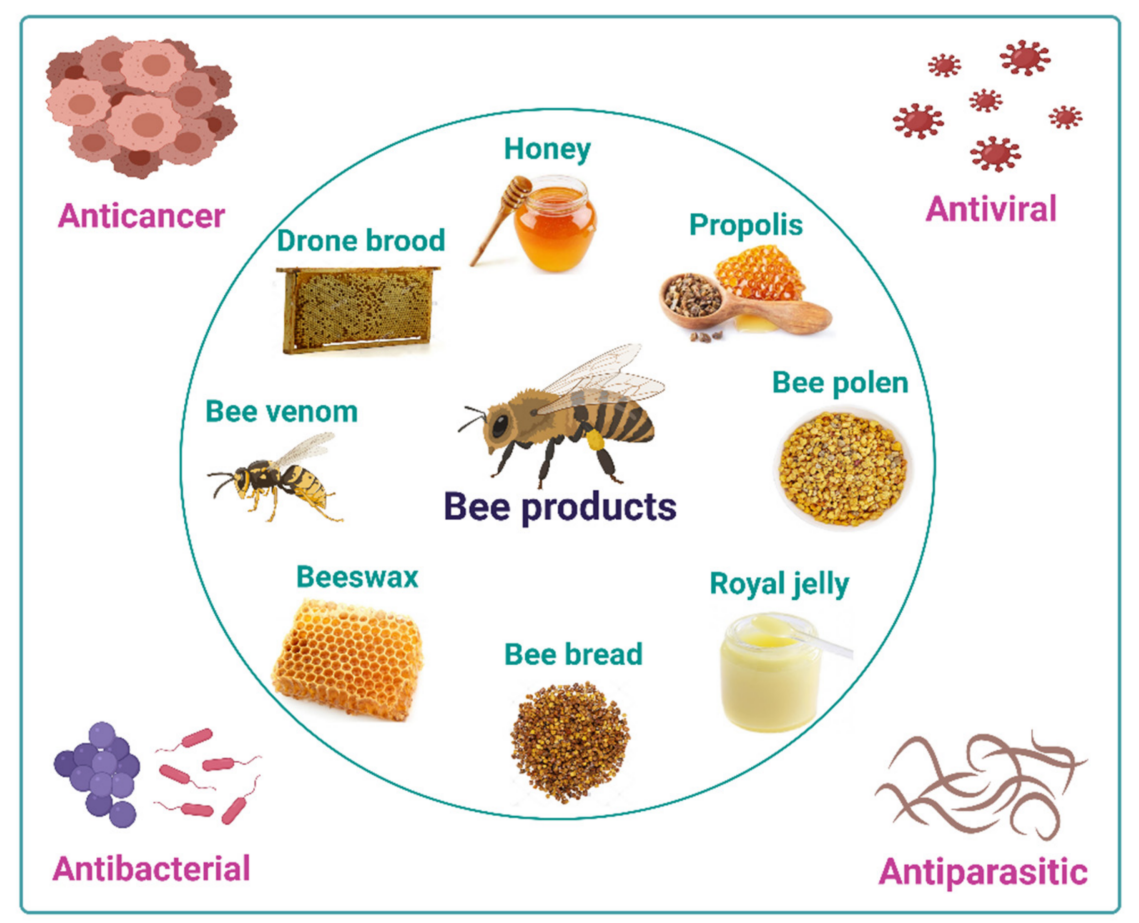

Figure 1. Types of bee products. 
In addition to their anticancer, antibacterial, and antiviral activities, bee products have been shown to exert antiprotozoal activity against the nematode model Caenorhabditis elegans and the intestinal parasite Giardia lamblia $[3,28,29]$. Studies showed that propolis yielded anti-malarial activities against Plasmodium vivax, P. ovale, P. malariae, and P. falciparum [28]. Honey and propolis were also used in ancient times for embalming bodies, and honey in traditional medicine was used for treating wounds and pain relief [8]. Royal jelly, another type of bee product, appears to have significant antimicrobial activity, as reported in several studies [27]. Beeswax, a lipid-based complex organic compound secreted by the younger worker bees in liquid form, forms in solidifies and scales when exposed to air $[27,30]$. In recent years, the crude extract of beeswax has been reported effective against pathogenic bacteria, viruses, and fungi [31]. Bee pollen is obtained from plants and transferred to hive as pollen loads. Load formation includes hydrating pollen with honey or nectar. In winter, pollen stored in honeycomb cells during winter fermentation undergoes lactic fermentation and produces bee bread. The bacteriostatic and bactericidal properties of bee bread and pollen are also well known [3].

Notwithstanding the immense application of bee products in the medical and pharmaceutical sectors [3], bee products also possess a substantial economic value. Bee products are primarily used in the food and cosmetics industries [8]. Honey is a great sweetener [32], and bee pollen is high in protein, fatty acids, and vitamins [33], suggesting their excellent dietary properties. Royal jelly can improve brain function and general wellbeing [34], while bee propolis and bee venom can be tapped as potential sources of anticancer $[35,36]$ and antiviral $[37,38]$ drug candidates. On the other hand, beeswax has antibiotic and skin softening properties; thus, this particular bee product has been extensively used in the cosmetics industry. This review discusses the importance of bee products in the medical-pharmaceutical fields as well as the potential use and prospective implication of bee products against cancer and different types of microbial pathogens and parasites.

\section{Types of Bee Products: Description and Components \\ 2.1. Honey}

Honey is a natural food substance generated by honeybees from deposits of plant and floral nectar, which are then coalesced with specific substances of honeybee, processed and stored in honeycombs to ripen [39]. The chemical components of honey depend on several factors including the species of honey-collecting bee, its plant source, climatic conditions, geographical region, and storage condition [40]. Honey consists of enzymes (acid phosphatase, amylase, catalase, diastase, glucose oxidase, invertase, and sucrose diastase) and amino acid monomers (alanine, asparagine, glutamine, glycine, and proline) [1]. Various phenolic acid such as caffeic-, cinnamic-, ferulic-, etc. (Figure 2) and several organic acids, mainly as gluconic and citric acid, followed by acetic acid, formic acid, and others in small amounts (Figure 3 ) are present in honey. These acids are responsible for the acidic $\mathrm{pH}$ of honey ranging from pH 3.4 to 6.1 [41]. Flavonoids (Figure 4) such as quercetin, kaempferol, chrysin, apigenin, hesperetin, galangin, catechin, luteolin, myricetin, and naringenin have also been reported in honey. The total phenolic content (TPC) and the total flavonoid content (TFC) of the honey samples varied from $4.2 \pm 0.6$ to $1.9 \pm 0.1 \mathrm{mg} Q E / 100 \mathrm{~g}$ and $31.5 \pm 2.1$ to $126.6 \pm 2.7 \mathrm{mg} \mathrm{GAE} / 100 \mathrm{~g}$, respectively [42].

Honey is sweet substance predominantly constituted by monosaccharides like fructose $(38 \%)$ and glucose (31\%) as major sugars, with disaccharides (sucrose, gentiobiose, isomaltose, kojibiose, laminaribiose, maltose, maltulose, nigerose, and trehalose) and trisaccharides (centose, erlose, isomaltosylglucose, isomaltotriose, isopanose, 1-ketose, maltotriose, melezitose, panose, and theanderose) in smaller concentrations (Figure 5) [1,43]. Vitamins and minerals are also reported at very low concentrations, about $0.02 \%$, including all of the water-soluble vitamins, and variable minerals such as $\mathrm{P}, \mathrm{Na}, \mathrm{Ca}, \mathrm{K}, \mathrm{S}, \mathrm{Mg}, \mathrm{Cl}$, $\mathrm{Si}, \mathrm{Rb}, \mathrm{V}, \mathrm{Zr}, \mathrm{Li}, \mathrm{Sr}$ [43,44]. In addition, volatile compounds are detected in honey, such as alcohols, aldehydes, benzene and its derivatives, terpene and its derivatives, ketones, pyran, furan, and acid esters $[9,45]$. The presence of these chemical composition provides 
better understanding of the beneficial effects of honey such as anticancer, antiallergic, antibacterial, antioxidant, antidiabetic, antiparasitic properties, antiulcer, anti-inflammatory, wound healing, and cardioprotective $[3,46,47]$.

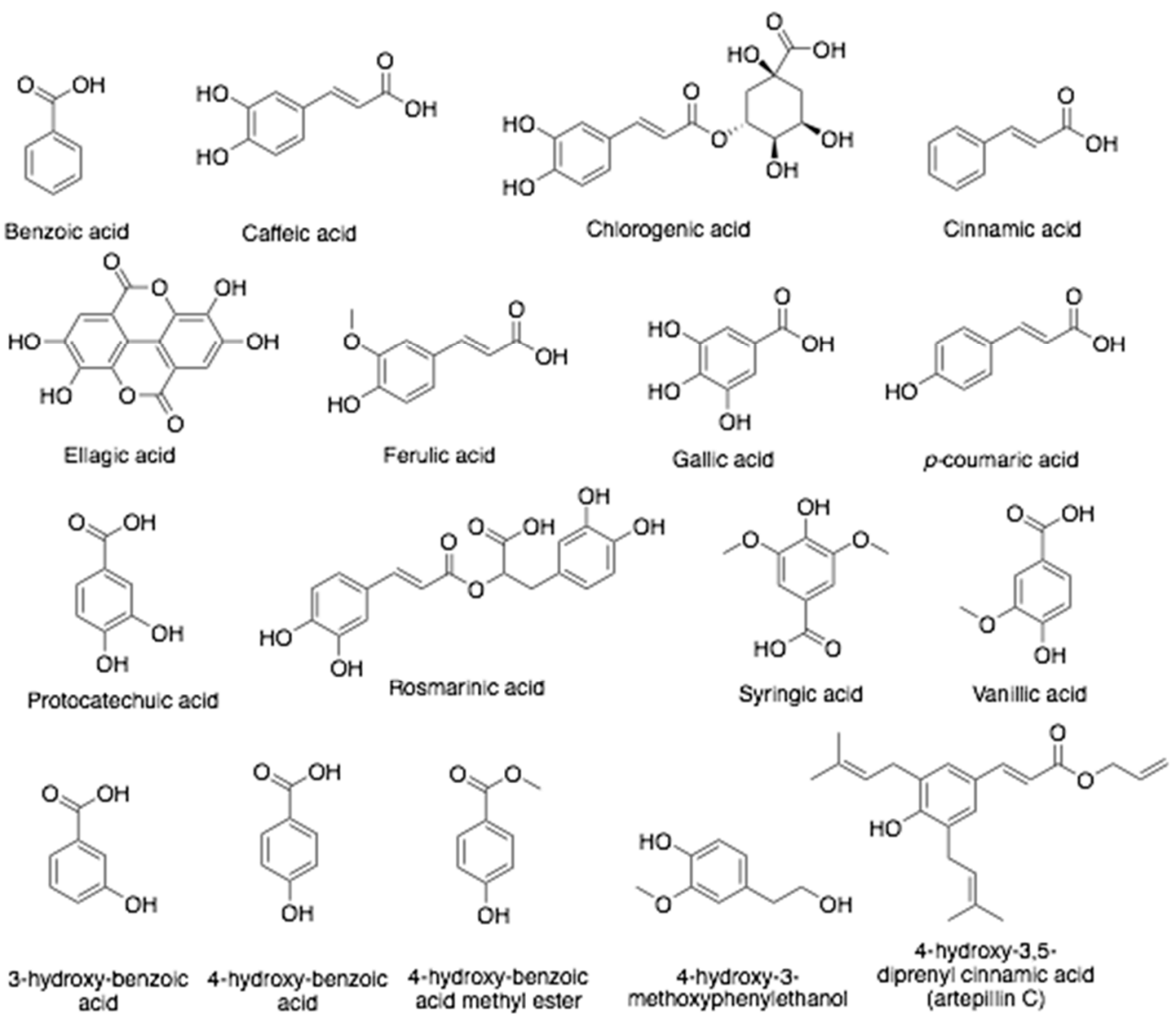

Figure 2. Chemical structures of phenolic acids found in bee products.

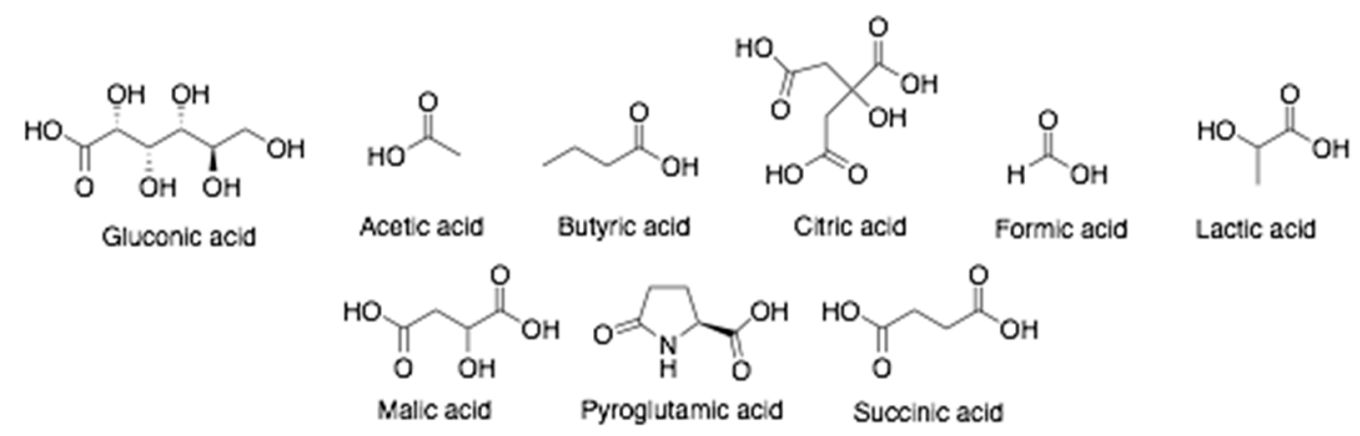

Figure 3. Chemical structures of organic acids found in honey. 
<smiles>COc1ccc(-c2cc(=O)c3c(O)cc(O)cc3o2)cc1</smiles><smiles>COc1ccc(-c2coc3cc(O)ccc3c(=O)c2=O)cc1</smiles><smiles>COc1ccc(C2C(O)C(=O)c3c(O)cc(O)cc3OC2c2ccc(C3CC(=O)c4c(O)cc(O)cc4O3)c(OC)c2)cc1O</smiles><smiles>O=C1C[C@H](c2ccc(O)cc2)Oc2cc(O)ccc2C1=O</smiles><smiles></smiles>

Malvidin<smiles></smiles>

Myricetin<smiles>O=C1CC(c2ccc(O)cc2)Oc2cc(O)cc(O)c21</smiles>

Naringenin<smiles>C[C@@H]1OC(OC2[C@H](Oc3cc(O)c4c(c3)OCCC4=O)O[C@H](CO)[C@@H](O)[C@H]2O)[C@H](O)[C@@H](O)[C@H]1O</smiles><smiles>O=C1c2c(O)cc(O)cc2O[C@H](c2ccccc2)[C@@H]1O</smiles>

Pinobanskin<smiles>COc1cc(O)c2c(c1)OC(c1ccccc1)CC2=O</smiles><smiles></smiles><smiles>O=c1c(OC2OC(CO)[C@@H](O)C(O)[C@H]2O)c(-c2ccc(O)c(O)c2)oc2cc(O)cc(O)c12</smiles>

Quercetin-3-O-glucoside

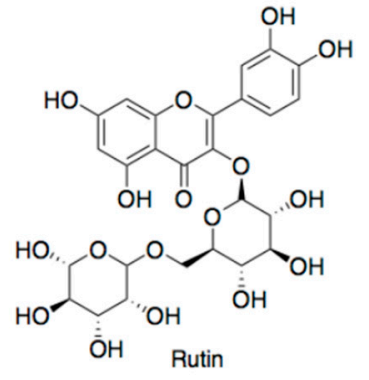

Figure 4. Chemical structures of flavonoids found in bee products. 
<smiles>OCC1O[C@@](CO)(O[C@@H]2O[C@H](CO)[C@@H](O[C@@H]3O[C@H](CO)[C@@H](O)[C@H](O)[C@H]3O)[C@H](O)[C@H]2O)O[C@H]1CO</smiles>
Eriose<smiles>OC[C@@H]1O[C@@](O)(CO)C(O)[C@H]1O[C@H]1O[C@H](CO)[C@@H](O)[C@H](O)[C@H]1O</smiles>

Maltose<smiles>O=CC(O)[C@H](O)[C@H](O[C@H]1CC(COC2O[C@H](CO)C(O)[C@H](O)C2O)[C@H](O)C(O)[C@H]1O)[C@@H](O)CO</smiles>

Panose<smiles>OCC1(O)OC[C@@H](O)[C@@H](O)[C@H]1O</smiles><smiles>OCC1O[C@H](O)[C@H](O)C(O)[C@H]1O</smiles>

Glucose<smiles>OCC1O[C@H](OCC2OC(O)[C@H](O)[C@H](O)[C@H]2O)C(O)[C@@H](O)[C@H]1O</smiles>

Isomaltose

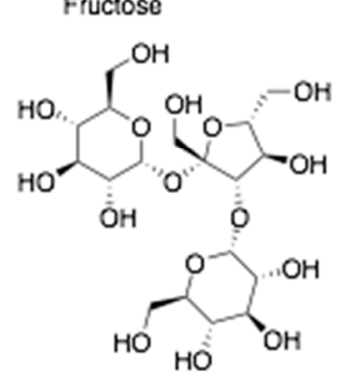

Melezitose<smiles>OCC1O[C@H](OC2(CO)O[C@H](CO)C(O)[C@H]2O)[C@H](O)[C@H](O)[C@H]1O</smiles>

Sucrose

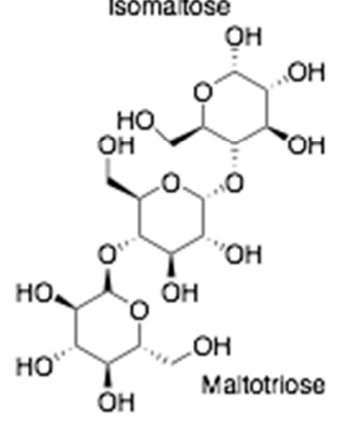

$\mathrm{OH}$<smiles>CCC1OC(O[C@]2(CO)OC(CO)[C@@H](O)C2O)C(O)C(O)[C@H]1O</smiles><smiles>COC1O[C@H](CO)[C@@H](O)[C@H](O)C1O</smiles><smiles>OCC1O[C@@H](O[C@@H]2OC(CO)[C@H](O)C(O)[C@H]2O)[C@H](O)C(O)[C@@H]1O</smiles>

Trehalose<smiles>O=C(CO)[C@H](O[C@@H]1OC(CO)[C@@H](O)C(O)[C@H]1O)[C@@H](O)C(O)CO</smiles>

Figure 5. Chemical structures of sugars found in bee products.

\subsection{Propolis}

Propolis or bee glue is a resinous substance that honeybees produce by mixing their salivary gland excretions with exudate accumulated from different parts of plants, mainly branches, bark, flower buds, leaves, and stems. Propolis comes from two Greek words: pro (defense) and polis (city or community) [48]. The color of propolis is varied, ranging from green to brown and reddish. Propolis possesses a sweet or pleasant odor, and becomes soft and sticky upon heating [49]. Typically, raw propolis consists of resins and balms (50-60\%), fatty acids and waxes (30-40\%), essential oils (5-10\%), and other components (5\%) such as enzymes (acid phosphatase, adenosine triphosphatase, glucose-6-phosphatase, and succinic dehydrogenase), vitamins (B1, B2, B6, C, and E), minerals ( $\mathrm{Mg}, \mathrm{Cu}, \mathrm{F}, \mathrm{Ca}, \mathrm{K}$, $\mathrm{Na}, \mathrm{Mn}$, and Zn) [50,51]. Propolis must be purified and dewaxed via solvent extraction to remove inert materials and preserve the phenolic fractions for commercialization [52].

Several monosaccharides (fructose and glucose) and a disaccharide (sucrose) are found in propolis. It also contains flavonoids (apigenin, chrysin, acacetin, catechin, daidzein, formononetin, naringenin, galangin, kaempferol, luteolin, liquiritigenin, myricetin, pinocembrin, rutin, and quercetin), phenolic acids (caffeic acid, chlorogenic acid, cinnamic acid, gallic acid, 4-hydroxybenzoic acid, 4-hydroxyhydrocinnamic acid, and 4-hydroxybenzoic acid-methyl ester), stilbene derivative (resveratrol), and terpenoids (Figure 6). The TPC and TFC of different samples from different sources such as Brazilian, Chinese, and Australian propolis range from 127-142 mg GAE/g and 33-53 mg QE/g, respectively [53]. Fatty acids such as arachidonic, cis-13,16-docosadienoic, cis-11,14,17-eicosatrienoic, cis- 
5,8,11,14,17-eicosapentaenoic, eicosadienoic, elaidic, heneicosylic, linoleic, oleic, palmitic, and palmitoleic acid are also present in propolis $[49,54]$. Propolis and its extracts confers several biological activities, such as antibacterial, anticancer, antifungal, anti-inflammatory, antimycotic, antioxidant, antiulcer, antiviral, cardioprotective, immunomodulatory, neuroprotective, and wound-healing $[35,55,56]$.<smiles>CC(C)c1cc2c(cc1O)C[C@]1(C)CCCC(C)(C(=O)O)C1C2</smiles>

12-Hydroxydehydroabietic acid

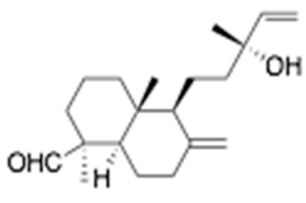

13-epi-torulosal

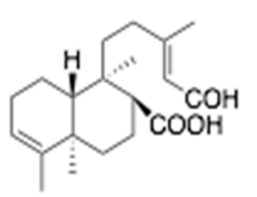

13-Symphyoreticutic acid<smiles>CCC1=CC2=CC[C@]3(C)[C@@](C)(C(=O)O)CCC[C@]3(C)[C@H]2CC1</smiles>

Abietic acid<smiles>CC1=CCCC[C@H]1C/C=C(\C)C=O</smiles>

Clerodane diterpene<smiles>C=C/C(C)=C/C[C@H]1CCCC[C@H]1C(=C)C</smiles>

Communic acid<smiles>CC(C)=CCCC(C)=CCCC(C)=CCO</smiles>

Farnesol<smiles>CC(C)c1cc2c(cc1O)C1(C)CCCCC1C=CC2C</smiles>

Ferruginol<smiles>C=C1CC[C@]2(C)[C@@H](C(=O)O)CCC[C@]2(C)[C@H]1CC[C@H](C)CC=O</smiles><smiles>C=C1CCC2C(C)CCCC2C1CC/C(C)=C/CO</smiles><smiles>C=C1CC[C@@H]2[C@@H](C(=O)O)CCC[C@@H]2C1C[C@@H](C)CC(=O)O</smiles><smiles>O=C(O)C1CCCC2C1CCC1C3CCC(=O)C3CCC21</smiles>

Imbricataloic acld Isocupressic acid Junicedric acid Kaurenoic acid<smiles>CC[C@H](C)CC[C@H]1[C@@H](C)CC[C@H]2C(C)CCC[C@@]21C</smiles>

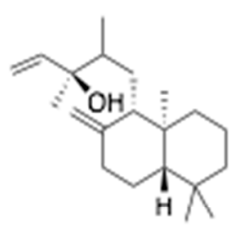

Manool<smiles>C=C1CCC2C(C)(C)CCCC2(C)C1CCC(C)CCO[C@H]1OC(C)[C@H](O)C(O)C1O</smiles><smiles>C=C1CCC2C(C)(C)CCCC2(C)C1CCC(C)CCO[C@H]1OC(C)[C@H](O)C(O)C1O</smiles>

Mannopyranoside<smiles>CC(C)c1cc2c(cc1O)[C@]1(C)CCC=CC2CC1=O</smiles>

Sugiol<smiles>CC(C)c1c(O)ccc2c1CC[C@H]1[C@@H](C)CCC[C@@]21C</smiles>

Totarol
Labdane<smiles>C=C[C@]1(C)C=C2CC[C@]3(C(=O)O)C(C)(C)CCC[C@]3(C)C2CC1</smiles>

Pimaric acid<smiles>CC(C)c1cc2c(cc1O)CCC1CCCCC21C</smiles>

Sempervirol

Figure 6. Chemical structures of terpenoids found in propolis.

\subsection{Bee Pollen}

One of the bee products, namely bee pollen, is produced by worker honeybees as the staple food for developing larvae $[57,58]$. This product results from the mixture of floral nectar, flower pollen, and enzymes with honeybee salivary substances [58]. The chemical compound of bee pollen depends on plant species, bee activities, and weather conditions [59]. The color of bee pollen is diverse, ranging from bright yellow to black and their shapes are also wide ranging: bell-shaped, cylindrical, thorny, or triangular. 
Bee pollen consist of single grains which are sometimes joined with two or more other grains [60].

Bee pollen has a high carbohydrate content (35-61\%), especially of monosaccharides (15-24\% fructose and $11-18 \%$ glucose), disaccharides (4-9\% sucrose) and other sugars such as arabinose, erlose, isomaltose, maltose, melibiose, melezitose, raffinose, rhamnose, ribose, trehalose, and turanose account for about $1 \%$ [59,61,62]. Moreover, bee pollen contains protein (14-30\%), including essential amino acids (10.4\%) such as histidine, isoleucine, leucine, lysine, methionine, phenylalanine, threonine, tryptophan, and valine $[60,62,63]$. Likewise, bee pollen contains lipids at higher amounts about $1-13 \%$ after carbohydrates and proteins. Among fatty acids, the most prevalent saturated fatty acids are myristic, palmitic, stearic acids (4.3-71.5\%) while the major unsaturated fatty acids are $\alpha$-linolenic, linoleic and oleic acids (1.3-53.2\%). Arachidonic, behenic, capric, caproic, caprylic, 11-eicosenoic, eicosatrienoic, elaidic, lauric, lignoceric acids also exist in bee pollen $[58,64]$.

Furthermore, bee pollen was reported to contain flavonoids, phenolic acids, and tannins [58]. The total phenolic content (TPC) and total flavonoid content (TFC) of bee pollen of distinct countries are 0.50-213 mg GAE/g and 1.00-5.50 mg QE/g, respectively [33]. The main flavonoids of bee pollen are present in about $1.4 \%$ including isorhamnetin, kaempferol, quercetin and its 3-O-glucosides, followed by apigenin, catechin, epicatechin, hesperetin, luteolin, naringenin $[60,65]$. On the other hand, the glucosides of anthocyanins, delphinidin, malvidin, and petunidin, were identified in bee pollen from Spain [66]. Bee pollen contains the following phenolic acids: caffeic, chlorogenic, ferulic, gallic, $p$-coumaric, $p$-hydroxybenzoic, protocatechuic, rosmarinic, syringic, and vanillic acid [58]. Bee pollen consists of vitamins, both water-soluble $0.6 \%$, such as vitamin B1, B2, B3, B5, B7, B6, B8, B9, $C$, and vitamin P; and fat soluble $0.1 \%$ such as provitamin A ( $\beta$-carotene), vitamin $E$ and $\mathrm{D}$ [67]. Minerals also belong to valuable substances in bee pollen, including macronutrients ( $\mathrm{Ca}, \mathrm{K}, \mathrm{Mg}, \mathrm{Na}, \mathrm{P}$ ) and micronutrients (Fe, Cu, Cr, Mn, Se, Si, Zn) [68]. Accordingly, bee pollen was reported as a valuable dietary supplement with therapeutic properties, including antibacterial, antioxidant, anti-atherosclerotic, anticancer, antiallergenic, anti-fungicidal, chemo-preventive, hepatoprotective, and immunomodulatory activities [69-71].

\subsection{Royal Jelly}

Royal jelly (bee's milk) is a viscous whitish to yellow jelly-like substance secreted by the mandibular and hypopharyngeal glands of worker honeybees [72,73]. It is slightly soluble in water with a strong smell and sour or sweet flavor and a pH of 3.1-3.9 [74]. Royal jelly plays an important role in honeybee larvae diet. It is fed exclusively to young larvae of workers and drones in their maturation process, and is provided to queen honeybees during their entire life cycle [75]. Generally, royal jelly contains water (50-70\%), carbohydrates $(30 \%)$, proteins $(27-41 \%)$, and lipids $(3-19 \%)[48,76]$. The major sugars present in royal jelly include fructose and glucose. Moreover, sucrose and other oligosaccharides like erlose, gentobiose, isomaltose, maltose, melezitose, raffinose, and trehalose are present in very small concentrations $[76,77]$. A unique group of nine soluble major royal jelly proteins (MRJPs 1-9) functions as the specific factors responsible for development of queen honeybees. The peptides of royal jelly including apisimin, jelleines, and royalisin, have been shown to yield antibacterial activity [3].

The lipid composition is reported as fatty acids $(80-85 \%)$, waxes $(5-6 \%)$, steroids (3-4\%) and phospholipids (0.4-0.8\%). Royal jelly fatty acids (Figure 7 ) are usually either uncommon short chain hydroxy and dicarboxylic acids (8-12 carbon atoms) such as 10hydroxy-trans-2-decenoic acid (10-HDA) and 10-hydroxydecanoic acid (HDAA), trans2-decenoic acid, 24-methylenecholesterol, 4-hydroxyperoxy-2-decenoic acid ethyl ester, and sebacic acid, 3-hydroxydecanoic, 9-hydroxy-2-decenoic, 8-hydroxyoctanoic, and 9hydroxydecanoic acid. Among them, 10-HDA and 10-HDAA are specific compounds of royal jelly [78-80]. 


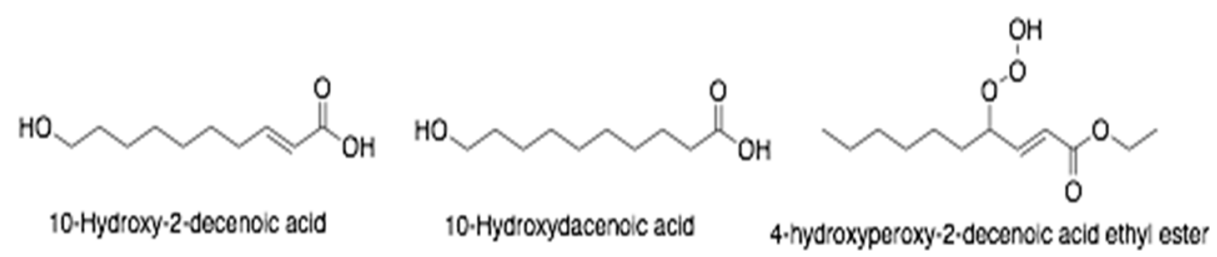

Figure 7. The main fatty acids of royal jelly.

Royal jelly consists of flavanones (pinobaskin, pinocembrin, hesperidin, naringin, and naringenin), flavones (acacetin, apigenin, chrysin, and luteolin), flavonols (fisetin, galangin, isorhamnetin, kaempferol, quercetin, and rutin), phenolic acids (caffeic acid, gallic acid, 4-hydroxy-3-methoxyphenylethanol, 4-hydroxybenzoic acid-methyl ester, 4hydroxybenzoic acid, 4-hydroxyhydrocinnamic acid, octanoic acids, 2-hexenedioic acid and its esters, dodecanoic acid and its ester, 1,2-benzenedicarboxylic acid, and benzoic acid) and other phenolic compounds such as hydroquinone, methyl salicylate, 2-methoxyp-cresol, 2-methoxyphenol, and pyrocatechol $[48,76]$. The TPC and TFC range from 3 to $9 \mathrm{mg} \mathrm{GAE} / \mathrm{g}$ and 0.1 to $0.5 \mathrm{mg}$ QE/g royal jelly, respectively [74]. In addition, royal jelly contains hormones (prolactin, testosterone, estradiol, and progesterone), minerals $(\mathrm{Cu}, \mathrm{Fe}$, $\mathrm{K}, \mathrm{Mg}$, and $\mathrm{Zn}$ ), and vitamins (B1, B2, B3, B5, B6, B9 and provitamin A) [79].

A variety of chemical components found in royal jelly exhibit several pharmacological properties, including antiaging, antiallergic, antibacterial, anticancer, antidiabetic, antiinflammatory, hypoglycemic, hypotensive, hepatoprotective, immunomodulatory, and neuroprotective effects [81-83].

\subsection{Bee Bread}

Bee bread (ambrosia) is a mixture of honey, pollen, and honeybee salivary secretion, which is then stored in the beehive and enclosed with honey and wax [84]. Bee bread is also called "fermented bee pollen" due to during the preservation, as the content is subjected to lactic fermentation in the beehive environment [85]. Therefore, the color of bee bread is caramel with a pungent flavor. Bee bread is the main food for larvae and the young worker bees that produce royal jelly [84].

Bee bread contains proteins, enzymes (saccharase, amylase, phosphatase, pepsin, trypsin and papain), minerals ( $\mathrm{Ca}, \mathrm{Mg}, \mathrm{P}, \mathrm{K}, \mathrm{Fe}, \mathrm{Zn}$, and $\mathrm{Mn}$ ), and vitamins (B-complex, $\mathrm{C}, \mathrm{D}$, and $\mathrm{E}$, mainly vitamin $\mathrm{P}$ and $\beta$-carotene). Vitamin $\mathrm{K}$, also present in bee bread, is not found in fresh bee pollen. Most kinds of bee bread contain $24-34 \%$ of carbohydrates. Flavonoids (kaempferol, isorhamnetin, apigenin, chrysin, naringenin, and quercetin) and phenolic acids ( $p$-coumaric, caffeic, ferulic and gallic acids) also show high concentrations [86]. The TPC and TFC of bee bread samples varies from $8.26 \pm 0.299$ to $43.42 \pm 0.779 \mathrm{mg}$ GAE $/ \mathrm{g}$ and $1.81 \pm 0.040$ to $4.44 \pm 0.125 \mathrm{mg}$ QE/g, respectively [87].

Fatty acids (Figure 8) such as arachidic acid, arachidonic acid, docosahexaenoic acid, eicosapentaenoic acid, linoleic acid, myristic acid, oleic acid, palmitic acid, and $\alpha$-linolenic acid, (9Z,12Z)-octadeca-9,12-dienoic, (9Z,12Z,15Z)-octadeca-9,12,15-trienoic, (Z)-octadec-9enoic, $(Z)$-icos-11-enoic, hexadecanoic and octadecanoic acids were also detected in bee bread [88]. The content of lactic acid in bee bread is higher than $3 \%$. The $\mathrm{pH}$ value of bee bread is 4.2, mainly due to the formation of lactic acid [86]. Bee bread was reported to have biological activities including antioxidant, antibacterial, antitumor, antihypertensive, neuroprotective, and antiseptic [52,89-91]. 


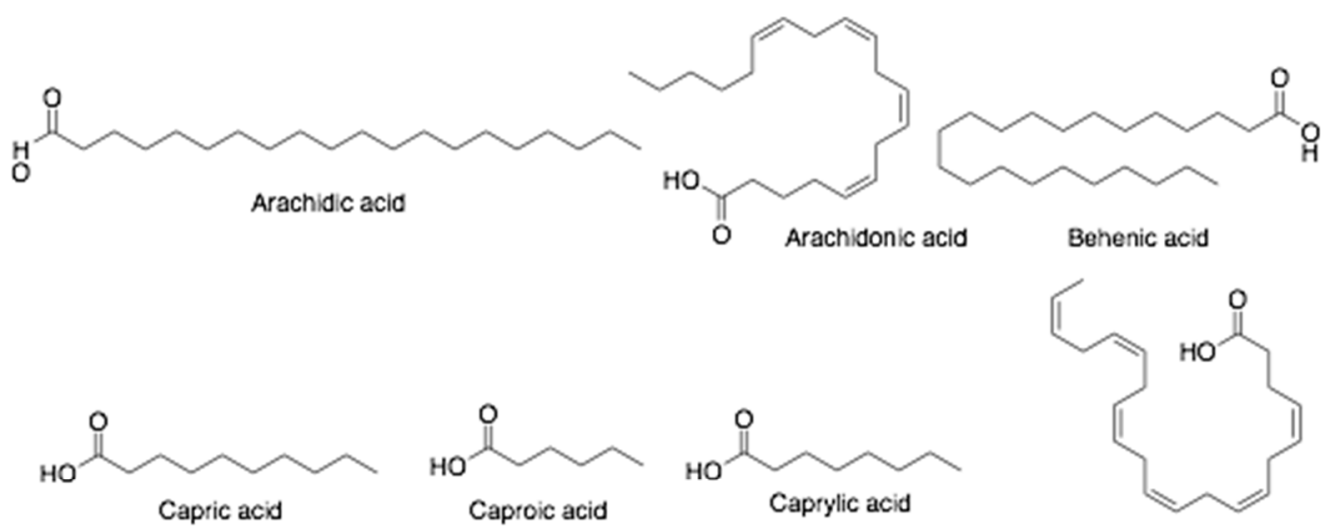<smiles>CC/C=C\C/C=C\C/C=C\C/C=C\C/C=C\CCCC(=O)O</smiles>

Eicosapentanoic acid<smiles>CCCCCCCCCCCCC(=O)O</smiles>

Lauric acid<smiles>CCC=CC=CC=CC=CCCCCCCCCCC(=O)O</smiles><smiles>CCCCCCCC=CCCCCCCCCC(=O)O</smiles>

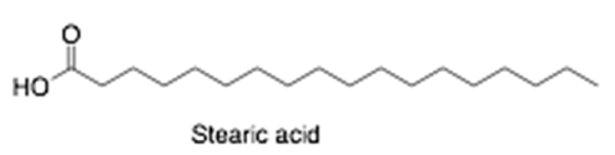

Docosanexanoic acid<smiles>CCCCCC/C=C/C=C/CCCCCCCCC(=O)O</smiles>

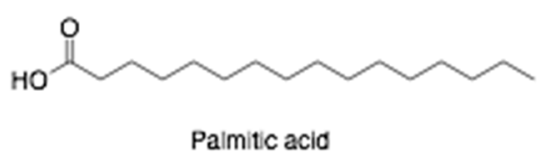<smiles>CC(O)CCCCCCCCCCCCCCCC(=O)O</smiles>

15-hydroxypalmitic acid

Figure 8. Chemical structures of fatty acids found in bee products, including bee bread.

\subsection{Beeswax}

Beeswax is a liquid substance secreted by the wax glands of younger worker honeybees that is used in the construction of the honeycombs. The color of beeswax turns from white to yellowish-brown after contact with honey and bee pollen. It dissolves completely in chloroform and partially in boiling alcohol [31]. Generally, beeswax consists of more than 300 components, including hydrocarbons (12-16\%, Figure 9), mainly heptacosane, nonacosane, hentriacontane, pentacosane and tricosane; free fatty acids (12-14\%) such as 15-hydroxypalmitic acid, oleic acid, and palmitic acid; linear wax monoesters and hydroxy monoesters (35-45\%), complex wax esters (15-27\%) containing 15-hydroxypalmitic acid or diols. Vitamins (A, B1, B4, B6 and P) and minerals (Ca, Cu, Fe, K, Mn, Na, P, and Zn) are also present in beeswax. Beeswax is used in the food, pharmaceutical, and cosmetic industries as an additive [31,52]. In addition, beeswax exhibits antimicrobial activities against Staphylococcus aureus, Salmonella enterica, Candida albicans and Aspergillus niger [31]. 


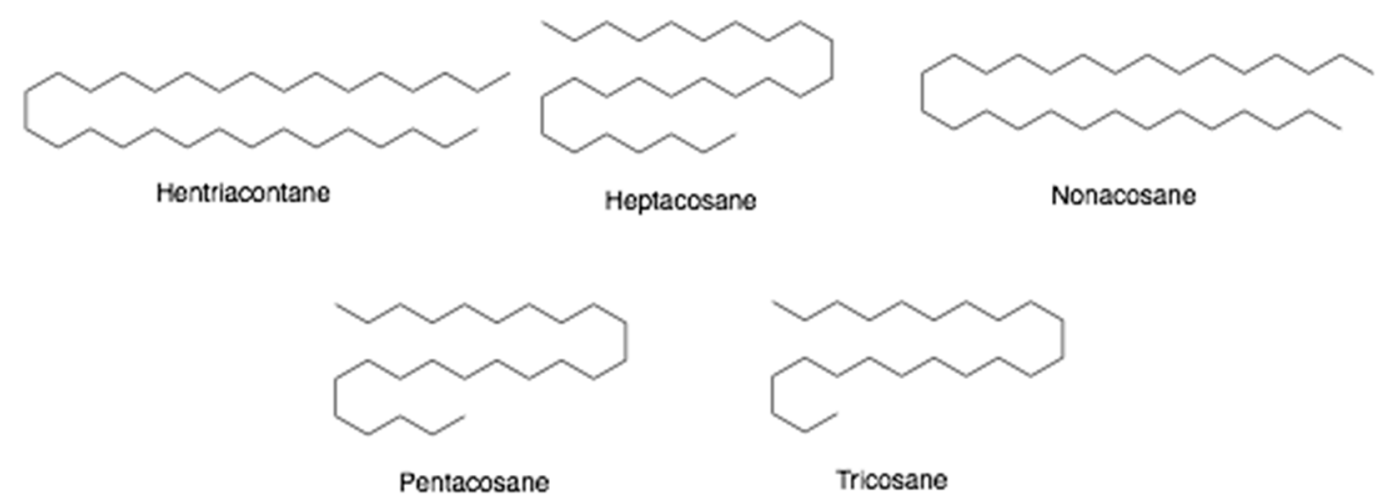

Figure 9. Chemical structures of hydrocarbons found in beeswax.

\subsection{Bee Venom}

Bee venom or apitoxin is a clear liquid secreted by the venom gland of honeybee located in the abdominal cavity. It is injected into victims by a stringer, causing an immunological response, mainly inflammation [3]. Bee venom is soluble in water with a $\mathrm{pH} 5-5.5$. Bee venom is highly hydrophilic due to the fact more than $80 \%$ of $\mathrm{BV}$ is water. Bee venom constituents include enzymes, predominantly two allergenic peptides: phospholipase A2 and hyaluronidase (Api m2), followed by icarapin, two serine proteases: Api SI and Api SII, and acid phosphatase or Api m3 [92,93]. Minerals such as Ca, Mg, and P are present in measurable concentrations. Volatile compounds are detected in bee venom such as isopentyl acetate, $n$-butyl acetate, isopentanol, $n$-hexyl acetate, $n$-octyl acetate, 2-nonanol, $n$-decyl acetate, benzyl acetate, benzyl alcohol, and (Z)-11-eicosen-1-ol (Figure 10) [36].
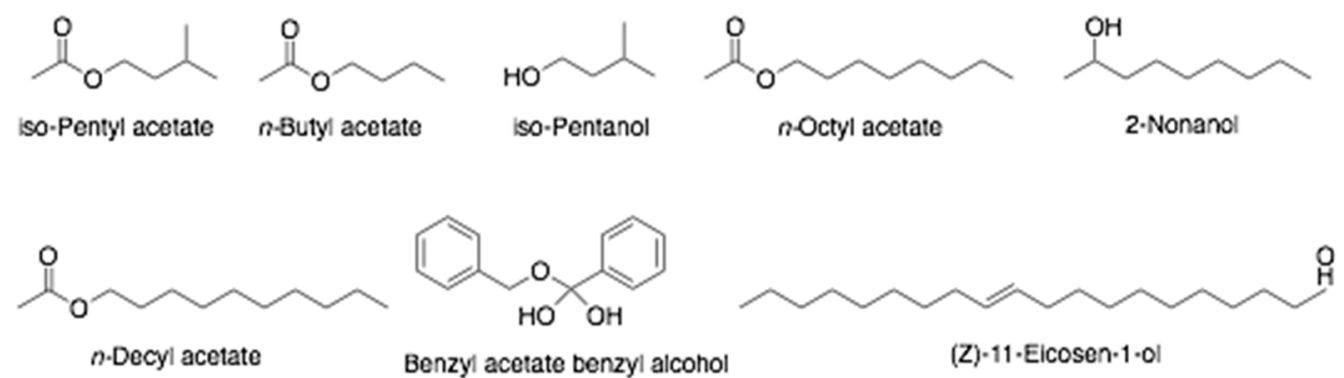

Figure 10. Chemical structures of volatile compounds found in bee venom.

Furthermore, bee venom is composed of a very complex mixture that contains more than 18 active components, including peptides (Figure 11), proteins, enzymes, sugars, amines, phospholipids, pheromones, and volatile compounds [94]. The major amphipathic polycationic peptides, mellitin and apamin, which are a unique component of bee venom. Other peptides such as mast-cell degranulating (MCD) peptide, adolapin, tertiapin, secapin, and cardiopep also present in bee venom $[94,95]$.

Bee venom was investigated as a potential Parkinson's disease therapy and rheumatoid arthritis, anti-inflammatory, antioxidant, antibacterial, anticancer, antimutagenic, antinociceptive, radioprotective, analgesic, immunomodulatory, anti-apoptotic or antisecretory activity $[7,96,97]$. 


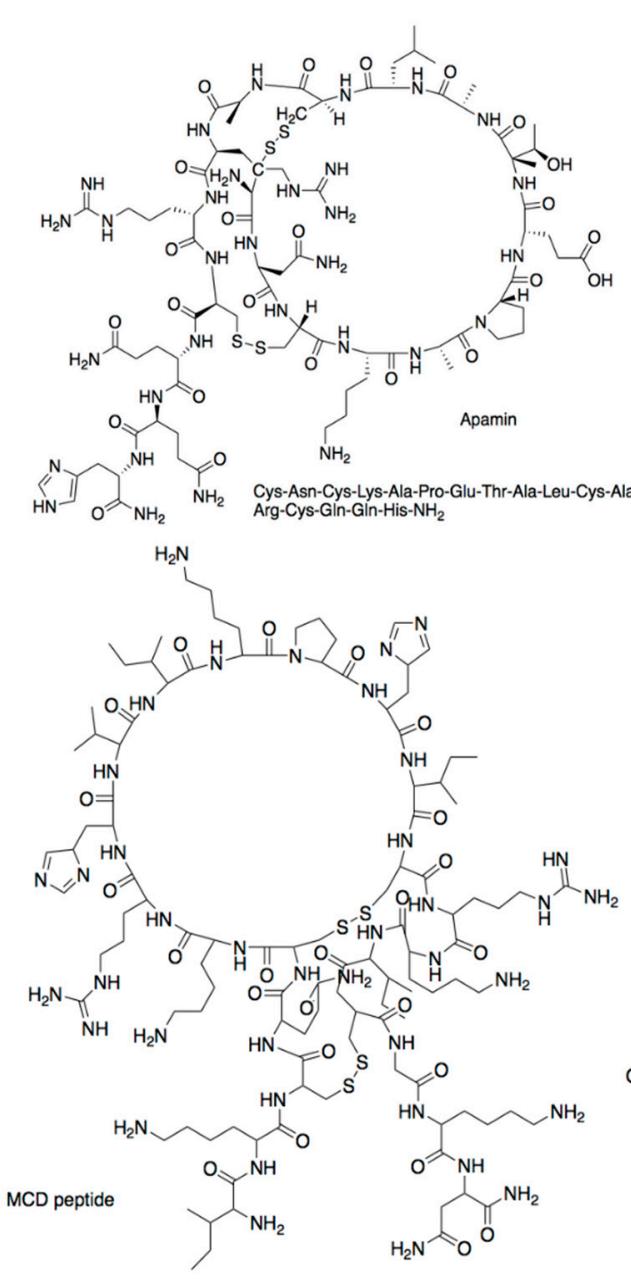

H-lle-Lys-Cys-Asn-Cys-Lys-Arg-His-Val-Ile-Lys-Pro-His-lle-CysArg-Lys-lle-Cys-Gly-Lys-Asn- $\mathrm{NH}_{2}$

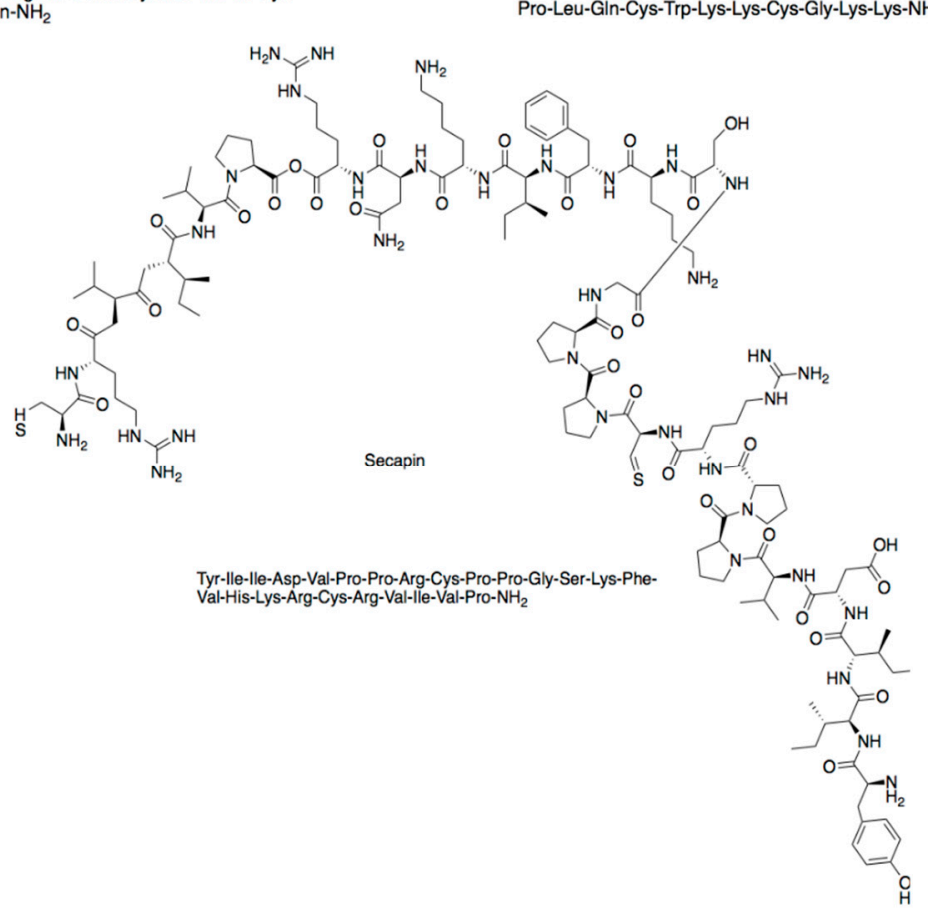

Figure 11. Chemical structures of peptides found in bee venom. H-Ala-Leu-Cys-Asn-Cys-Asn-Arg-IIE-Ile-Ile-
Pro-Leu-GIn-Cys-Trp-Lys-Lys-Cys-Gly-Lys-Lys-NH

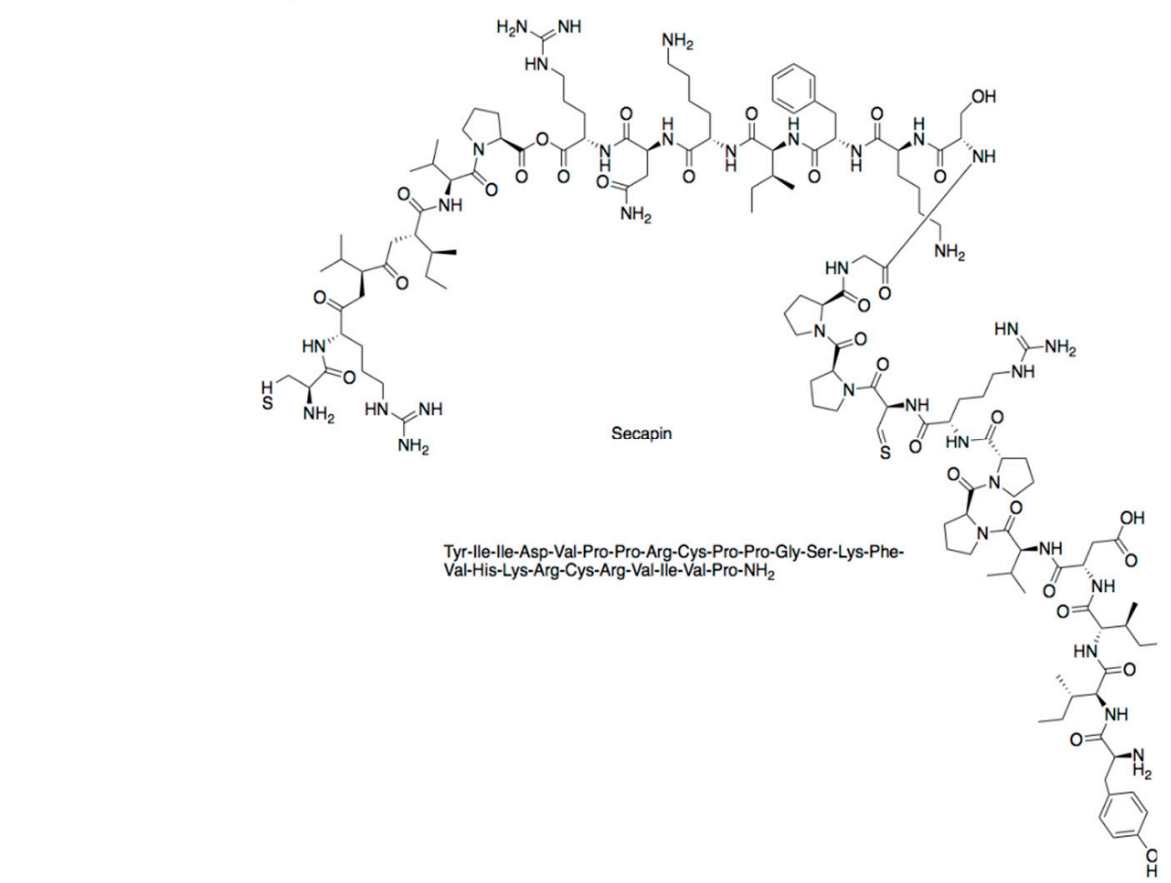
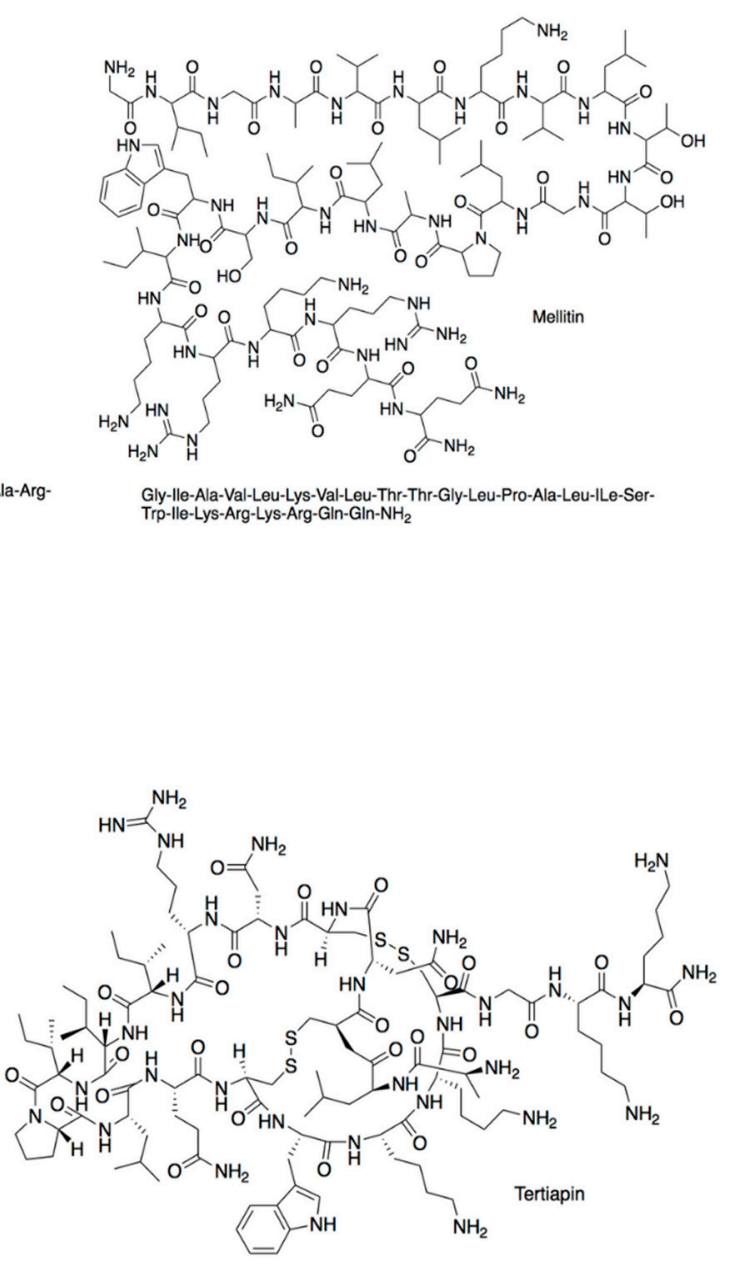


\subsection{Drone Brood}

Drone brood or apilarnil is a little-known bee product acquired by the collection of drone larvae from drone cells (3-11 days after hatching) [98]. Drone brood is a milky, sweet substance with a slightly acidic taste. The odor of drone brood is similar to that of royal jelly. Drone brood is a tenacious substance of creamy consistency with a yellowish gray color [98].

Drone brood consists of $9-12 \%$ protein, including amino acids, mainly $6.5 \%$ glutamic acid, $2.1 \%$ alanine, $3.6 \%$ aspartic acid, $3.6 \%$ leucine, $2.9 \%$ lysine, $3.4 \%$ proline, $2.3 \%$ valine, and followed by histidine, methionine, phenylalanine, and tryptophan. Drone brood contains carbohydrate $(6-10 \%)$, lipid 5-8\%, ash 2\%, dry matter (approximately $25-35 \%$ ), hormones (female sex hormones: estradiol, prolactin, progesterone; and male sex hormones: testosterone), vitamins (B1-B6, A, D, and E), and minerals (Mg, Ca, P, Na, Zn, Mn, $\mathrm{Fe}, \mathrm{Cu}$, $\mathrm{K}$, and Se). The biological activity of drone brood includes antioxidant, antiatherosclerotic, androgenic and adaptogenic effects [99].

\section{Anticancer Properties of Bee Products}

There is currently growing interest in bee products particularly in terms of their potential anticancer activities. It has been previously reported that some bee products can interfere with the development of cancer cells. In this review, we highlight several studies regarding the most recent anticancer activities of bee products (summarized in Table 1). In addition, we also discuss the potency of each presented bee product and the possible mechanisms by which the products or their constituents act in inhibiting the cancer cell growth.

As one of the most utilized bee products, honey has been an undoubtedly an important bee product not only because of its nutritional values but also its medicinal properties. In terms of anticancer activities, honey exerts cytotoxicity against several cancer cell lines. For instance, in an MTT assay, honey samples obtained from Morocco decreased the cell viability of human colorectal cancer (HCT-1) cell cultures [100]. Further investigation to identify the constituents in the active honey samples revealed that phenolic compounds such as rosmarinic acid, tannic acid, caffeic acid, coumaric acid, gallic acid, ferulic acid, syringic acid, catechin, and pyrogallol were present [100]. Meanwhile, manuka honey is reported to actively inhibit the proliferation of MCF-7 at various concentrations [101-104]. Acacia honey also exhibited anticancer activity against MCF-7 at a concentration of $5.5 \%$ $v / v$ [105]. Beside HCT-1 and MCF-7, honey (0.5 to $1 \mathrm{mg} / \mathrm{mL}$ ) was also reported to inhibit the growth of PC-3, a prostate cancer cell model [106].

These anticancer activities are suggested to be influenced by the substances that are present in honey and hence, correlate to its mechanisms in inhibiting the growth of cancer cells [107]. In general, honey consists of inverted sugar like glucose and fructose at a relatively high concentration but some compounds such as flavonoids, polyphenols, amino acids, carotenoids, vitamins and minerals may also be found [107,108]. Other phytochemicals such as simple polyphenols and flavonoids (chrysin, apigenin, caffeic acid, chrysin, galangin, kaemfereol, pinocembrin, pinobanksin and quercetin) can also be found $[109,110]$. In the evaluation of the anticancer activity of chestnut honey, a quinoline alkaloid was shown to be responsible for the apoptosis mechanism against castration-resistant prostate cancer (CRPC) cells [111]. Other mechanisms by which honey and its constituents interfere with the development of cancer cells are prevention of cellular damage by free radicals by the antioxidant constituents in honey, induction of apoptosis via cellular signalling pathways and immunomodulation activity, and estrogenic effects [102,107,111,112].

The antiproliferative potencies of propolis have also been studied extensively in recent years. Unlike honey, propolis is not usually tested in a form of a raw product, but rather, it is extracted using methanol, ethanol or other organic solvents before the pharmacological activities are evaluated because of its resinous consistency. Cytotoxic tests against A549 cells, a model of human lung cancer cell, revealed that propolis extract obtained from Turkey indicated inhibition of cell growth [113]. The ethyl acetate fraction of propolis 
from Saudi Arabia is reported to inhibit Jurkat cells (a T-lymphocyte leukemia model), as well as human liver carcinoma cells (HEP-62) and squamous carcinoma (SW-756) cell lines [114]. Similarly, propolis from Lebanon was also reported to suppress the growth of Jurkat cells [115]. Interestingly, when tested in other carcinoma cell models such as U251 (glioblastoma) and MDA-MB-231 (breast adenocarcinoma), the hexane fraction is the only fraction to show inhibition against these cell models compared to the aqueous and dichloromethane fraction [115]. These results suggest that less polar substances in the propolis may be responsible for the anticancer activities.

Simple polyphenol compounds such as caffeic acid, chrysin, $p$-coumaric acid, galangin, ferulic acid, and pinocembrin are among the most reported phytochemicals to be found in propolis. These compounds have also been suggested to play significant roles in the suppression of cancer cell growth. Czyewska compared the anticancer activity of extracted propolis to the mixture of polyphenols containing chrysin, galangin and $p$-coumaric acid using CAL-27 cells, a human tongue squamous cancer model. Although the results also showed that the mixture of polyphenolic compounds exhibited higher cytotoxicity than the propolis extract [116], it is important to note that the mixture was tested at higher concentration of polyphenols instead of mimicking the relative concentration each substance found in the tested propolis. One possible mechanism in which propolis may interfere with the development of cancer is by the enhancement of the immune system. As an example, propolis samples from northern Morocco which are reported to be cytotoxic against MCF-7, HCT and THP-1 are shown to enhance production of interleukin-10 (IL-10) and decrease TNF- $\alpha$ and IL-6 production [117], suggesting an immunomodulatory activity of this propolis as a possible mechanism to combat the tested cancer cells. The other mechanisms underlying the anticancer activities of propolis are predicted to be related to its ability to interact with microtubules and induction of tubulin depolymerisation [114], activation of apoptosis via caspase-3, -8 and -9 [116], and reduction of proline in cancer cells via proline dehydrogenase/proline oxidase activity [118].

Bee pollen is another bee product that has been examined for its anticancer properties. Compared to other bee products, bee pollen seems to yield a relatively weaker anticancer potency. In an in vitro assay of anticancer activities using mouse B16 melanoma cells, up to $100 \mu \mathrm{g} / \mathrm{mL}$ of bee pollen was not able to reduce the cultured cell viability [119]. However, it inhibits intracellular tyrosinase (TYR) and interfere with the expression of mRNA corresponding to TYR and tyrosinase receptor, TRP-1 and TRP-2 [119]. Bee pollens collected from different places in South Korea were tested against human prostate adenocarcinoma (PC-3), human lung carcinoma (NCI-H727), human lung carcinoma (A549), MCF-7, and AGS, resulting in $\mathrm{IC}_{50}$ values between 0.9 to $>25 \mathrm{mg} / \mathrm{mL}$ [120]. Stronger anticancer properties were shown by enzymatically cleaved bee pollen proteins, also known as the hydrolysates. It was reported that the hydrolysate peptides lower than $65 \mathrm{kDa}$ in molecular weight were able to inhibit ChaGo-K1 cells, a human bronchogenic carcinoma model, at an $\mathrm{IC}_{50}$ of $1.37 \mu \mathrm{g} / \mathrm{mL}$ [121]. From the above data, it is known that higher concentrations of bee pollen are required to inhibit certain cancer cell lines. However, it should also be seen as a sign that bee pollen may be less toxic to normal cells although we did not describe its toxicity profiles in this review.

Bee venoms have also been reported to exhibit anticancer properties [122,123]. One of the most notable components in bee venom is melittin, a major protein substituent found in most venoms of bee species under the Apis genus. Melittin from Apis florea and Apis mellifera have been shown to exhibit a relatively strong anticancer activity $\left(\mathrm{IC}_{50}=3.38\right.$ and $4.97 \mu \mathrm{g} / \mathrm{mL}$, respectively) when challenged against A375 (human malignant melanoma), comparable to that of doxorubicin [124]. A cytotoxicity examination of melittin against HeLa, WiDr and Vero cell lines was also reported, showing anticancer activities with $\mathrm{IC}_{50}$ values of 2.54, 2.68 and $3.53 \mu \mathrm{g} / \mathrm{mL}$, respectively [125]. Melittin also exerts cytotoxic activity against MDA-MDB-231, a human breast cancer cell line, with an $\mathrm{IC}_{50}$ of $6.25 \mu \mathrm{g} / \mathrm{mL}$ [126]. At a concentration of $0.5 \mu \mathrm{g} / \mathrm{mL}$, melittin is able to reduce the viability of cultured AGS cells, a gastric cancer model [127]. The anticancer mechanism of melittin is possibly 
related to its ability to activate the apoptotic pathway via cytochrome-c discharge and therefore activates caspase- 9 which leads to the activation of caspase-3 [124]. In relation to this, further investigation was carried out which indicated that melittin prevents the invasion and migration of melanoma cells in a metastatic cell model, mainly though interference with F-actin reorganization and epidermal growth factor receptor (EGFR) activation [124]. Although it is encouraging that melittin seems to be a promising anticancer agent, there is a growing concern that this protein may also be active against normal cells. Besides, bee venom in general is also highlighted for its adverse cytolytic effects. Therefore, measures to avoid or minimize the disadvantages of bee venom administration in cancer therapy have been attempted. Some of the solutions to this problem are the application of specialized drug delivery systems, i.e., nanoparticles, to carry the toxin protein $[128,129]$, and conjugation of the toxin to specific cancer-targeting biomolecules $[7,130,131]$.

The anticancer potential of other bee products such as royal jelly and bee bread was also reported. Royal jelly's effect on mammary cancer has been examined using $4 \mathrm{~T} 1$ cells inoculated in mice. The results revealed that the tumor weight was significantly reduced and further evaluation of the mechanisms revealed changes in interleukin (IL)-2, IL-10 and interferon (INF)- $\alpha$ concentrations in mice plasma [132]. In a recent review regarding the anticancer activity of royal jelly, it was highlighted that the main compound in royal jelly that is thought to be responsible for its anticancer activity is called 10-hydroxydecenoic acid (10-HDA), since it is exclusively found in royal jelly (among the other bee products) at relatively high concentration [133]. However, in another study, it was reported that royal jelly or 10-HDA alone were not effective in inhibiting the growth of human colorectal carcinoma (Caco-2) cells but a mixture of royal jelly and human IFN- $\alpha 3 \mathrm{~N}$ at a ratio of $2: 1$ significantly reduced the cell viability [134]. Miyata et al. expanded the research further to test the anticancer potency of royal jelly in a randomized double-blinded clinical trial. Although the anticancer activity of royal jelly was found to be insignificant, there was a reduction on the adverse events frequencies among patients receiving royal jelly as adjuvant for tyrosine kinase inhibitors $[135,136]$. In contrast, Osama et al. reported that although a certain potency of royal jelly in protecting the renal functions of patients is observed, it was found to be insignificant in anticancer therapy of cisplatin [137]. Apart from that, the investigation on the mechanisms in the activity of royal jelly as anticancer revealed that it may enhance production of cytokine from mononuclear cells to suppress the growth of U937, a leukemia cell model [138]. Meanwhile, bee bread, a bee product that is closely related to royal jelly, was also shown to have antiproliferative activities against Caco-2 and PC-3 cell lines [139]. Bee bread has also been tested against MCF-7, HeLa, HepG-2 and non-small cell lung cancer (NCI-H460), although the potency was relatively low to moderate $\left(\mathrm{GI}_{25}>400\right.$ to $68 \mu \mathrm{g} / \mathrm{mL}$ ) [89]. It consists mainly of polyunsaturated and monounsaturated fatty acids [139], but the substances that are thought to be responsible for the anticancer potency are its flavonoids and polyphenolic constituents including isorhamnetin-O-glycoside, quercetin-O-glycoside, herbacetin glycosides, kaempferol, and myricetin [89].

In general, the anticancer activities of bee products presented in this review reveal that bee products are potential sources of anticancer agents with a wide range of cytotoxic mechanisms. We are aware that anticancer activities of the bee products were mostly assessed using in vitro MTT assays. Hence, a detailed evaluation on these products against cancer-bearing animal models is required to obtain a deeper insight on the influence of different factors on the potencies of these natural products. Additionally, the toxicity profiles of each bee products against normal cells should be evaluated since many anticancer agents are not only toxic to cancer cells but also to normal tissues. 
Table 1. Anticancer potentials of selected bee products.

\begin{tabular}{|c|c|c|c|c|c|}
\hline Bee Products & Identified Substance(s) & Tested Cell Lines & Type(s) of Cancer & Possible Mechanism(s) & Ref. \\
\hline Honey & $\begin{array}{l}\text { Gallic acid, caffeic acid, } \\
\text { syringe acid, chlorogenic acid, } \\
\text { p-coumaric acid, ferulic acid, } \\
\text { catechin, quercetin, chrysin }\end{array}$ & PC-3 & $\begin{array}{l}\text { Human prostate } \\
\text { adenocarcinoma }\end{array}$ & Not examined & [106] \\
\hline Honey (Tualang) & Not examined & MCF-7, MDA-MB-231 & Breast cancer & $\begin{array}{l}\text { Modulation of apoptotic signalling } \\
\text { pathway by enhancing the } \\
\text { expression of p53, p21 and FADD } \\
\text { protein }\end{array}$ & [112] \\
\hline Honey (Manuka) & Not examined & $\begin{array}{l}\text { MCF-7, } \\
\text { MDA-MB-231 }\end{array}$ & Breast cancer & $\begin{array}{l}\text { Reduction of interleukin (IL)- } 6 \text { and } \\
\text { inhibition of pY-STAT3 signalling. } \\
\text { Inhibition of cell invasion and } \\
\text { migration }\end{array}$ & [102] \\
\hline $\begin{array}{l}\text { Honey (Chesnut } \\
\text { honey) }\end{array}$ & $\begin{array}{l}3-2^{\prime} \text {-pyrrilonidinyl-kynurenic } \\
\text { acid }\end{array}$ & CRPC & $\begin{array}{l}\text { Castration-resistant prostate } \\
\text { cancer }\end{array}$ & Induction of apoptosis via caspase-3 & [111] \\
\hline Bee pollen & $<65$ kDa peptides & ChaGo-K-1 & $\begin{array}{l}\text { Human bronchogenic } \\
\text { carcinoma }\end{array}$ & $\begin{array}{l}\text { Induction of apoptosis (biomolecular } \\
\text { pathway not known yet) }\end{array}$ & [121] \\
\hline Propolis & $\begin{array}{l}\text { Pinocembrin as the major } \\
\text { constituent }\end{array}$ & MCF-7, HCT and THP-1 & $\begin{array}{l}\text { Breast cancer, human colon } \\
\text { cancer, and human } \\
\text { leukemia model }\end{array}$ & $\begin{array}{l}\text { Enhanced production of } \\
\text { interleukin-10 (IL-10) and decreased } \\
\text { production of TNF-a and IL-6 }\end{array}$ & [117] \\
\hline Propolis & $\begin{array}{l}\text { Triterpenes, steroids } \\
\text { derivatives, and diterpenes }\end{array}$ & $\begin{array}{l}\text { Jurkat } \\
\text { HEP-62 } \\
\text { SW-756 }\end{array}$ & $\begin{array}{l}\text { T-lymphocyte leukemia, } \\
\text { human liver carcinoma, } \\
\text { Squamose carcinoma. }\end{array}$ & $\begin{array}{l}\text { Interaction with microtubules; } \\
\text { induction of tubulin } \\
\text { depolymerisation }\end{array}$ & [114] \\
\hline Propolis & $\begin{array}{l}\text { Chrysin, galangin and } \\
p \text {-coumaric acid }\end{array}$ & CAL-27 & $\begin{array}{l}\text { Human tongue squamosa } \\
\text { cancer }\end{array}$ & $\begin{array}{l}\text { Activation of apoptotic cascades via } \\
\text { caspase- } 3,-8 \text { and }-9\end{array}$ & [116] \\
\hline Propolis & $\begin{array}{l}\text { Chrysin, caffeic acid, } \\
p \text {-coumaric acid and ferulic } \\
\text { acid }\end{array}$ & CAL-27 & $\begin{array}{l}\text { Human tongue squamosa } \\
\text { cancer }\end{array}$ & $\begin{array}{l}\text { Decreased level of proline in cancer } \\
\text { cells via proline } \\
\text { dehydrogenase/proline oxidase } \\
\text { activity }\end{array}$ & [118] \\
\hline Propolis & $\begin{array}{l}\text { 3-O-methylquercetin, chrysin, } \\
\text { caffeic acid, CAPE, galangin } \\
\text { and pinocembrin }\end{array}$ & MCF-7, HGC-27, A549 & $\begin{array}{l}\text { Breast cancer, human gastric } \\
\text { carcinoma, human lung } \\
\text { adenocarcinoma }\end{array}$ & $\begin{array}{l}\text { Induction of apoptosis, promotion of } \\
\text { cell cycle arrest via activation of p21 }\end{array}$ & [140] \\
\hline Royal jelly & 10-hydroxy-2-decenoic acid & MCF-7 & Breast cancer & Not examined & [133] \\
\hline Royal jelly & Not examined & Mouse 4T1 & Mouse mammary carcinoma & $\begin{array}{l}\text { Increased concentration of IL- } 2 \text { and } \\
\text { interferon (INF)- } \alpha \text {; decreased level } \\
\text { of IL-10 }\end{array}$ & [132] \\
\hline Royal jelly & 10-hydroxy-2-decenoic acid & U-937 & Leukemia & $\begin{array}{l}\text { Induce secretion of cytokines by } \\
\text { mononuclear cells }\end{array}$ & [138] \\
\hline Bee bread & $\begin{array}{l}\text { Polyunsaturated fatty acids } \\
(51 \%) \text { and monounsaturated } \\
\text { fatty acids }(9.9 \%)\end{array}$ & $\begin{array}{l}\text { Caco-2 } \\
\text { PC-3 }\end{array}$ & $\begin{array}{l}\text { Human colorectal } \\
\text { adenocarcinoma, Human } \\
\text { prostate adenocarcinoma }\end{array}$ & Not examined & [139] \\
\hline Bee bread & Flavonoids and polyphenols & $\begin{array}{l}\text { MCF-7 } \\
\text { HeLa }\end{array}$ & $\begin{array}{l}\text { Breast cancer } \\
\text { Cervical cancer }\end{array}$ & Not examined & [89] \\
\hline Bee venom & Mellitin & AGS & Gastric cancer & $\begin{array}{l}\text { Disruption of cell membrane } \\
\text { causing necrosis to the affected cells }\end{array}$ & [127] \\
\hline Bee venom & Mellitin & A375 & Human lung cancer & $\begin{array}{l}\text { Induction of apoptosis via activation } \\
\text { of caspase- } 9 \text { and caspase- } 3 \text {, } \\
\text { inhibition of invasion and migration } \\
\text { of melanoma cells through } \\
\text { interference of f-actin reorganisation } \\
\text { and epidermal growth factor } \\
\text { receptor (EGFR) activity }\end{array}$ & {$[124]$} \\
\hline
\end{tabular}

\section{Bee Products as Prospective Sources of Antibacterial and Antiviral Agents}

Bacterial and viral infections are two of the top causes of deaths worldwide. An increasing number of reports describing the development of bacterial and viral resistance, including in the form of polymicrobial infections, against currently available antibiotics and antivirals has urged the use of alternative products with potential activities against those 
two types of pathogens [141-144]. One of the commodities equipped with such activities are bee products [3,145-149]. Bee products such as honey, propolis, bee pollen, royal jelly, beebread, and bee venom have been broadly used in the traditional healing practices, including in the management of infectious diseases [49,147,150,151]. A selected list of bee products with antibacterial properties can be seen in Table 2 . With their enormous medical and pharmaceutical potentials, bee products shall be considered as one of best prospective sources to discover novel antibacterial and antiviral drugs.

Honey is comprised of more than 150 different substances, including nutrients such as carbohydrates, proteins, vitamins, minerals, water, and different types of polyphenolic compounds [149,150]. Geographical setting and climate condition have been suggested to play a decisive role in determining the composition and concentration of active compounds in the nectar [151], thus the quality and, subsequently, the antimicrobial and antiviral activities of the blossom honey can vary from one to another.

Honey exerts broad spectrum antimicrobial efficacy against different types of pathogenic bacteria [152] and viruses [153]. The antibacterial activities of honey are influenced by numerous physical and chemical properties such as high sugar content (high osmolality), low $\mathrm{pH}$, glucose oxidase activation that leads to hydrogen peroxide production, and in addition to that, the biological action of chemical compounds present in honey such as bacteriocins, bee defensin, methylglyoxal, 3-phenyllactic acid (PLA), and the so-called Major Royal Jelly Proteins (MRJPs) [154]. Honey has been shown to yield exceptional antibacterial activities against both Gram-positive (including methicillin-resistant $S$. aureus (MRSA)), and Gram-negative bacteria, which are frequently linked to skin infections [155]. Manuka honey, a type of honey derived from Leptospermum scoparium, has been reported to have a strong antibacterial activity against S. aureus, S. epidermidis, Enterobacter aerogenes, Salmonella enterica serovar Typhimurium, Klebsiella pneumoniae, and Escherichia coli [156].

Honey has been reported to yield biological effects not only against bacterial pathogens but also against human pathogenic viruses, including the latest threat of SARS-CoV-2 [157]. Overall reports indicate that honey is a prospective sources of antiviral compounds with excellent in vitro efficacy against varicella zoster virus (VZV) [158] and rubella virus [159]. Honey, either in a single use or in a combination with other products, has also been reported to demonstrate antiviral activity against influenza virus [13], herpes simplex virus (HSV)-1 [160], and respiratory syncytial virus (RSV) [14]. In addition, honey can improve the life of patients infected with human immunodeficiency virus (HIV) by promoting the proliferation of lymphocytes and by maintaining the hematological and biochemical parameters at optimal conditions [160,161].

The antibacterial activity of other types of bee products such as propolis, bee pollen, royal jelly, bee bread, and bee venom have also been reported [3,145,148,162]. Propolis exerts its antibacterial potential using two distinct mechanisms: either by promoting the activation of host immune responses (indirect action) or via direct interaction of its component(s) with certain parts of bacteria, for example by disruption of cell wall synthesis and alteration of membrane potential $[148,163]$. Research carried out by a Brazilian group demonstrated the antibacterial activity of propolis against MRSA [164], most likely due to the presence of artepillin C. Separate studies by Japanese and Chilean groups confirmed the effectiveness of propolis against Porphyromonas gingivalis [165] and Streptococcus mutans [166], respectively, suggesting the potential use of propolis in the management of periodontal diseases. In addition, the high content of kaempferide, artepillin $\mathrm{C}$, drupanin and $p$-coumaric acid present in the ethanolic extract of propolis has been shown to positively correlate with its excellent antioxidant and antimicrobial activity against diverse types of pathogenic bacteria, including S. aureus, S. saprophyticus, Listeria monocytogenes, and E. faecalis [167]. In addition to its antibacterial effect, propolis has also been reported to exert antiviral activity against many human pathogenic viruses, including human herpesviruses [15], influenza virus [16-18], HIV [19], human T-cell leukemia-lymphoma virus type 1 (HLTV-1) [20], Newcastle disease virus (NDV) [21], RSV [22], poliovirus (PV)-type 1 [23], and dengue virus (DENV) [24]. Recently, flavonoids of propolis and honey such as 
rutin, naringin, and quercetin, have been suggested as candidates for potential adjuvant treatment against SARS-CoV-2 [168].

Bee-collected pollen, simply called bee pollen, and bee bread are two bee products commonly known for their dietary value [145]. Based on the published literature, bee pollen and bee bread demonstrate good antimicrobial activities against several human bacterial and viral pathogens [145]. However, like honey and propolis, the antimicrobial activities of bee pollen and bee bread are varied, and largely dependent on the geographical source of the collected samples and the solvents used in the extraction process [145]. Chilean bee pollen extracts inhibited the growth of Streptococcus pyogenes I.S.P. 364-00 but did not show any biological activities against S. aureus ATCC 25923, P. aeruginosa ATCC 27853, and E. coli ATCC 25922 [169]. Interestingly, Slovakian bee pollen extract demonstrated good antibacterial features against a clinical isolate of E. coli CCM 3988 [170]. Nonetheless, a general observation in several studies is that the antibacterial action of bee pollen is much higher towards Gram-positive bacteria than their Gram-negative counterparts $[169,171-173]$ with some exceptions $[174,175]$. It is important to note, however, that almost all the antibacterial data were generated in vitro, so it is urgent to confirm the antibacterial efficacy of bee products using currently available vertebrate [176-179] or invertebrate [180-185] in vivo model systems.

In addition to their antibacterial efficacies, bee pollen and bee bread have been reported to display antiviral activities. For example, bee pollen of date palm was found to be active against HSV-1 and HSV-2 [25] and bee pollen extracts of Korean Papaver rhoeas was fairly effective against influenza viruses (strains of H1N1, H3N2, and H5N1) [26]. The antiviral activity of bee pollen was most likely due to the action of flavonoids such as luteolin, galangin, kaempferol, and quercetin. Luteolin has been shown as one of the most potent inhibitors of the neuraminidase of influenza virus [26], thus is a prospective anti-influenza drug candidate (as a class of neuraminidase inhibitor). In addition, quercetin was shown to interact with the HA2 subunit of hemagglutinin and inhibit the entry of influenza virus into the host cells [186]. Quercetin-mediated inhibition of hemagglutinin might play a determinant role in the prevention of the hemagglutinin-sialic acid interaction that is required in influenza virus entry. With an increasing rate of viral resistance against the available anti-influenza drugs, such a mechanism shall play a future role in the pharmacological treatment of influenza virus infections.

The emergence of SARS-CoV-2, the causative agent of coronavirus disease (COVID)19, in late 2019 has increased researchers' interest in the medical and pharmaceutical potentials of bee products. Several published literatures have encouraged the use of bee products such as honey, propolis, bee pollen, bee bread, and even bee venom, in the management of COVID-19. Lima et al., for example, argued that apitherapy is one of alternative ways that can be tapped to prevent and/or to manage some of the COVID19-associated symptoms [27]. Indeed, honey and other bee products contain a number of compounds that have been shown effective as antivirals, thus potentially promising against SARS-CoV-2 [27,157,187]. On the basis of such argument, several randomized clinical trials are now carried out to investigate whether the use of honey and propolis in the management COVID-19 are truly effective [27]. 
Table 2. Antibacterial activity of selected bee products.

\begin{tabular}{lllll}
\hline Bee Products & Country & Bacteria & Assay Method & Results
\end{tabular}

Bee Products

Country

Assay Method

Majority of Australian Lectospermum

honey tested in the experiments

Leptospermum honey $(80$

different honeys derived Australia

Staphylococcus aureus (ATCC In vitro (phenol demonstrated non-peroxide antibacterial

from Leptospermum species) 25923) equivalence assay)

activity (NPA) and to a greater extent

correlates to their high content of methylglyoxal (MGO) and dihydroxyacetone (DHA)

21 types of honey of different botanical source, derived from the Olympus mountain
Clinical isolates of

methicillin-resistant $S$. aureus In vitro (agar well

Greece (strain 1552) and

carbapenem-resistant $P$. aeruginosa (strain 1773) diffusion assay and microtiter plate assay)

All honey samples yielded antibacterial activity against both tested bacteria.

Some honey samples were active in a manner dependent on the presence of hydrogen peroxide and proteinaceous compounds

\section{Sesamum indicum honey}

(seven types of sesame

honey obtained from

different location in West

Bengal)

India

Salmonella enterica serovar

Typhi, S. enterica serovar

Typhimurium, Escherichia coli and Vibrio cholerae

Methicillin sensitive- (ATCC

New Zealand's Manuka

Methicillin sensitive- (ATCC

29213 and 10 strains of MSSA In vitro (disc

Honey (UMF +20, UMF +16, New Zealand,

+10), Sidr honey, and Nigella Saudi Arabia

sativa honey

clinical isolates) and

diffusion assay and

methicillin resistant $S$. aureus microbroth dilution

(ATCC 26112 and 10 strains of assay)

MRSA clinical isolates)

Melipona beecheii honey

(Cuba); Manuka honey

(New Zealand), Apis

mellifera honey (Cuba), and

African A. mellifera honey

New Zealand, 51 clinical isolates (34

Cuba, and

Kenya

Gram-positive, 17

Gram-negative)

In vitro (disc

diffusion assay and

microbroth dilution assay)

The antibacterial activity of sesame

honey against the tested

enteropathogens was good, with the best [190]

recorded activity was against both

Salmonella species

Manuka honey demonstrated

bactericidal activity against both MSSA

and MRSA while Sidr and Nigella sativa

honey yielded only bacteriostatic effect

at tested concentrations

All honey tested in the study

demonstrated good antibacterial and

antibiofilm activity with Cuban $M$

In vitro (microtiter

plate assay for

both

(Kenya)

Ten samples of honey of different origins (polyfloral, linden, acacia, manna, and Romania sunflower)
S. aureus, Staphylococcus

epidermidis, S. enterica serovar

Typhimurium, Bacillus cereus, In vitro (disc

B. subtilis, Pseudomonas

diffusion assay)

aeruginosa, E. coli, and Listeria

monocytogenes

S. aureus (ATCC 25923) and

Klebsiella pneumoniae (ATCC 13883)
In vitro (agar

diffusion and broth dilution assays)

All honey samples demonstrated good antibacterial activity against all tested pathogens with $S$. aureus and $P$. aeruginosa were the most sensitive ones. It seems that the origins and the color of honey, but not acidity, play a role in the antibacterial activity of honey

The examined Australian propolis

demonstrated antibacterial effect against

S. aureus (bactericidal) but did not yield

methanol)

Brazilian brown and green propolis (extracted either using ethanol, hexane, or dicholometane)

S. aureus (ATCC 6538), B.

Brazil subtilis (ATCC 6633) and Micrococcus luteus (ATCC 10240)
In vitro

(micro-dilution assay) any effect on the K. pneumoniae

Of all samples examined in the study, the dichloromethane extract of both brown propolis and green propolis yielded the highest antibacterial effect against the tested pathogens

S. aureus (ATCC 43300), $S$ aureus (ESA 654), S. epidermidis (ATCC 12228), S. epidermidis (ESA 675), Enterococcus faecalis (ATCC 43300), E. faecalis (ESA

Propolis of T. fiebrigi bees (extracted using ethanol)
Brazil
553), K. pneumonia (ATCC 4352), K. pneumoniae (ESA 154), P. aeruginosa (ATCC 15442), P. aeruginosa (ESA 22),

Proteus mirabilis (ATCC 43300) and P. mirabilis (ESA 37)
The Brazilian propolis demonstrated antibacterial effect against all tested

(micro-dilution assay) microorganisms but mainly active 
Table 2. Cont.

\begin{tabular}{|c|c|c|c|c|c|}
\hline Bee Products & Country & Bacteria & Assay Method & Results & Ref. \\
\hline $\begin{array}{l}\text { Red propolis of Africanized } \\
\text { Apis mellifera }\end{array}$ & Brazil & $\begin{array}{l}\text { Standard strains of E. coli } \\
\text { (ATCC } 25922 \text { ) and } S . \text { aureus } \\
\text { ATCC } 6538 \text { and the clinical } \\
\text { isolates of E. coli } 06 \text { (EC06), P. } \\
\text { aeruginosa } 03 \text { (PA03), P. } \\
\text { aeruginosa } 24 \text { (PA24) and } S . \\
\text { aureus } 10 \text { (SA10) }\end{array}$ & $\begin{array}{l}\text { In vitro } \\
\text { (micro-dilution assay) }\end{array}$ & $\begin{array}{l}\text { The Brazilian red propolis demonstrated } \\
\text { antibacterial activity against all tested } \\
\text { pathogens, including the clinical isolate } \\
\text { ones. The range of MIC values was } \\
\text { dependent on the pathogen species } \\
(128-512 \mu \mathrm{g} / \mathrm{mL} \text { for } E \text {. coli strains), } \\
(64 \mu \mathrm{g} / \mathrm{mL} \text { to } \geq 1024 \mu \mathrm{g} / \mathrm{mL} \text { for } S \text {. } \\
\text { aureus strains), and ( } 512 \mu \mathrm{g} / \mathrm{mL} \text { for } P \text {. } \\
\text { aeruginosa strains) }\end{array}$ & [197] \\
\hline $\begin{array}{l}\text { Red propolis, green } \\
\text { propolis, and brown } \\
\text { propolis (traditionally } \\
\text { extracted using ethanol or } \\
\text { supercritical extraction } \\
\text { method) }\end{array}$ & Brazil & $\begin{array}{l}\text { S. aureus (ATCC 25923) and } \\
\text { Enterococcus sp. (ATCC 29712), } \\
\text { Klebsiella sp. (ATCC } \\
\text { 1706/700603), and E. coli } \\
\text { (ATCC 25922) }\end{array}$ & $\begin{array}{l}\text { In vitro } \\
\text { (micro-dilution assay) }\end{array}$ & $\begin{array}{l}\text { Of all samples, Brazilian red propolis } \\
\text { extract yielded the highest antibacterial } \\
\text { activity. Green propolis extract } \\
\text { demonstrated weak to moderate } \\
\text { antibacterial activity for most samples } \\
\text { and brown propolis extract did not yield } \\
\text { any antibacterial effect against the tested } \\
\text { strains. None of the examined samples } \\
\text { was active against } E \text {. coli }\end{array}$ & [198] \\
\hline $\begin{array}{l}19 \text { propolis samples } \\
\text { (collected from six different } \\
\text { regions and extracted using } \\
\text { methanol) }\end{array}$ & Chile & $\begin{array}{l}\text { Methicillin-sensitive } S . \text { aureus } \\
\text { (ATCC 25923), } \\
\text { methicillin-resistant S. aureus } \\
\text { (ATCC 43300), E. coli (ATCC } \\
\text { 25922), and the clinical isolates } \\
\text { of Pseudomonas sp., E. coli, P. } \\
\text { mirabilis, Salmonella enteritidis, } \\
\text { Salmonella sp. and Yersinia } \\
\text { enterocolitica }\end{array}$ & $\begin{array}{l}\text { In vitro } \\
\text { (micro-dilution assay) }\end{array}$ & $\begin{array}{l}\text { The antibacterial effect of propolis } \\
\text { obtained from central valley was better } \\
\text { than the ones collected from the Andreas } \\
\text { slopes or the coastal areas. The samples' } \\
\text { MICs were ranging from } 31.5 \text { to } \\
>1000 \mu \mathrm{g} / \mathrm{mL} \text { and the ones with } \\
\text { MIC } \leq 62.5 \mu \mathrm{g} / \mathrm{mL} \text { demonstrated good } \\
\text { antibacterial effect against Pseudomonas } \\
\text { sp., E. coli, S. enteritidis, and } Y \text {. } \\
\text { enterocolitica }\end{array}$ & [199] \\
\hline
\end{tabular}

\section{S. aureus, Staphylococcus}

saprophyticus, S. epidermidis, $S$.

Propolis collected from different geographical either ethanol or water) regions (extracted using

\section{Germany, Klebsiella oxytoca, E. coli, E. coli}

Irlandia, O157.H7, P. aeruginosa,

Czech Republic Salmonella choleraesuis, Shigella flexneri, Haemophilue influenza, Acinetobacter baumanii,

Burkholderia cepacia, $Y$. enterocolitis, Enterobacter cloacae, one strain of MRSA, and one strain of

Vancomycin-resistant

\section{P. aeruginosa PAO1 (ATCC}

15692) and transgenic $P$.

Propolis and bud poplar resins (extracted using ethanol)

Italy aeruginosa (P1242) with the luciferase gene and luciferin In vitro substrate (under the control of a constitutive P1 integron promoter)

24 propolis samples (collected from different geographical location in Morocco; hydro-alcoholic extracts)

\section{Propolis of Populus alba, $P$.}

nigra, P. tremula, Acer

pseudoplatanus, Betula

verucosa, Pinus silvestris, and Poland

Aesculus hippocastanum

(extracted using methanol

or dichlorometane)
S. aureus (ATCC 6538) and

Morocco three clinical isolates of MRSA In vitro (disk (MRSA2, MRSA 15, and diffusion method) MRSA 16) pneumoniae, Streptococcus

pyogenes, Streptococcus oralis,

Streptococcus agalactia,

Streptococcus thermophiles, $B$.

subtilis, Enterococcus

casseliflavus, K. pneumonia, enterococci (VRE)

Both ethanol and water propolis extracts demonstrated good antimicrobial activity against most of Gram-positive bacteria (range of MICs: $0.08-5 \mathrm{mg} / \mathrm{mL}$ ), with the Irish propolis yielded the highest bactericidal effect followed by Czech and German. All propolis extracts In vitro
(micro-dilution assay) $\begin{aligned} & \text { demonstrated moderate antibacterial } \\ & \text { against MRSA and VRE and also against }\end{aligned}$ $\beta$-lactamase positive $H$. influenzae, and $S$. pneumoniae. Propolis ethanol extract, but not water extract, yielded moderate antibacterial activity against Gtam-negative pathogens tested in the study (MICs: $0.6-5 \mathrm{mg} / \mathrm{mL}$ )

Both ethanol extracts (propolis and bud poplar resins) demonstrated good antibacterial activity against $P$. aeruginosa (micro-dilution assay) biofilm and negatively affected the swimming and swarming motility properties of $P$. aeruginosa

Propolis extract (MIC $0.36 \mathrm{mg} / \mathrm{mL}$ ) was able to attenuate the virulence of $S$. aureus ATCC 6538 and the MRSA strains. [202] The impairment of biofilm formation was also observed
S. aureus (ATCC 25923), $S$ epidermidis (ATCC 12228), $P$. aeruginosa (ATCC 227853), E. In vitro (disk coli (ATCC 25922), E. cloacae diffusion method) (ATCC 13047), and $K$. pneumoniae (ATCC 13883)
The dichloromethane extract of propolis demonstrated good antibacterial activity against all tested pathogens (MICs: $0.90-1.34 \mathrm{mg} / \mathrm{mL}$ ) 
Table 2. Cont

\begin{tabular}{|c|c|c|}
\hline Bee Products & Country & Bacteria \\
\hline $\begin{array}{l}\text { Green propolis (extracted } \\
\text { using ethanol, methanol, } \\
\text { diethyl ether or water) }\end{array}$ & Taiwan & $\begin{array}{l}\text { S. aureus (BCRC 10780, BCRC } \\
10781 \text { and BCRC 10451), } \\
\text { MRSA (ATCC 43300), B. } \\
\text { subtilis (BCRC 10255), L. } \\
\text { monocytogenes (BCRC 14845), } \\
\text { P. aeruginosa (BCRC 10944), } \\
\text { and E. coli (BCRC 10675) }\end{array}$ \\
\hline $\begin{array}{l}29 \text { bee pollen samples } \\
\text { (collected during the dry } \\
\text { seasons of 2016, 2017, and } \\
\text { 2018; extracted using } \\
\text { ethanol) }\end{array}$ & Chile & $\begin{array}{l}\text { S. aureus (ATCC 25923), P. } \\
\text { aeruginosa (ATCC 27853), E. } \\
\text { coli (ATCC 25922), and S. } \\
\text { pyogenes (I.S.P. 364-00) }\end{array}$ \\
\hline
\end{tabular}

$\begin{array}{ll} & \text { Taiwanese green propolis extracts } \\ & \text { demonstrated good antibacterial activity } \\ \text { In vitro } & \text { against MRSA and all propolins, } \\ \text { (micro-dilution assay) } & \text { particularly propolin C, yielded good } \\ & \text { efficacy against S. aureus, B. subtilis, and } \\ \text { L. monocytogenes }\end{array}$

Ref.

Three Greek bee pollen (collected from from Cistus creticus L. (rock rose) at three different locations; Greece extracted using ethanol, butanol, dichloromethane, or cyclohexane)
S. aureus (ATCC 25923), S. epidermidis (ATCC 12228), $P$. aeruginosa (ATCC 227853), E. coli (ATCC 25922), E. cloacae (ATCC 13047), and $K$. pneumoniae (ATCC 13883)
In vitro (disk

diffusion method and broth dilution method)

All bee pollen extracts (collected in three different years) demonstrated good antibacterial activity against $S$. pyogenes [169] but did not yield antibacterial effect on $S$. aureus, P. aeruginosa, and E. coli

The butanol extract demonstrated good antibacterial activity against all pathogens tested in the study, probably due to the high content of flavonoids,

In vitro such as quercetin and kaempferol (micro-dilution assay) such as quercetin and kampferol
glucosides. No antimicrobial activity was seen in both cyclohexane and dichlorometane extracts

All bee bread and propolis extracts demonstrated good antimicrobial activity against all tested bacteria (MIC:

Bee bread and propolis of Stingless bee (Heterotrigona Malaysia
itama species; extracted itama species; extracted using ethanol or hexane)
In vitro (disk S. aureus, B. subtilis, E. coli, and diffusion method and Salmonella broth dilution method)
$<6.67-33.33 \mu \mathrm{L} / \mathrm{mL}$ ), with higher

preference to Gram-positive (S. aureus and B. cereus) than Gram-negative bacteria (E. coli and Salmonella). Ethanol extracts yielded stronger antibacterial activity than their hexanic counterparts

Bee pollen extracts yielded higher antibacterial activity against

In vitro (disk E. faecalis (ATCC 51299), $M$.

Castanea sativa Mill. pollen grains (collected at Erfelek (4 sites) and Ayanc1k (5 sites) Turkey district of Sinop; extracted using methanol)

Vancomycin-resistant Enterococcus (VRE), E. coli diffusion method) Gram-positive bacteria than their

(ATCC 11293), and $K$.

Gram-negative counterparts
Fusobacterium mucleatum, Aggregatibacter

Royal jelly sample Singapore actinomycetemcomitans, Porphyromonas gingivalis, and Prevotella intermedia
Royal jelly demonstrated good

$\begin{array}{ll}\text { In vitro } & \text { antibacterial activity against } \\ \text { (micro-dilution assay) } & \text { periodontopathic bacteria tested in the }\end{array}$ study
Royal jelly sample (Yamada Bee Farm, Okayama, Japan) Japan

Bee bread sample (hydromethanolic extract) Morocco
P. aeruginosa (PAO1) wild-type In vitro strain and four clinical isolates (micro-dilution assay (TUH-54, TUH-124, TUH-188, and microtiter plate and TUH-213) biofilm assay)
Royal jelly did not yield antipseudomonal activity at concentration of $50 \% w / v$. However, at concentration of less than $25 \%$, antiadherent activity was observed on both the abiotic surface and the epithelial cell model

\section{Hydromethanolic extract of bee bread} demonstrated antibacterial activity cereus (food isolate), $L$ monocytogenes (NCTC 7973), E. In vitro coli (ATCC 35210), E. cloacae (micro-dilution assay) (human isolate), $S$. Typhimurium (ATCC 13311) against all tested pathogens (MIC: $0.04-0.175 \mathrm{mg} / \mathrm{mL}$; MBC: $0.08-0.35 \mathrm{mg} / \mathrm{mL}$ )

All bee bread samples yielded good antibacterial activity against antibiotic-resistant Gram-positive and Gram-negative bacteria tested in the study. The antibacterial strength of bee bread samples on certain bacteria was

Bee bread (five different regions of Ukraine; extracted using ethanol)
Ukraine S. aureus (CCM 4223), E. coli enterica (CCM 3807), and Bacillus thuringiensis (CCM 19)
In vitro (disk diffusion method) varied, mainly depends on the geographical location of sample collection 
Table 2. Cont

\begin{tabular}{|c|c|c|c|c|c|}
\hline Bee Products & Country & Bacteria & Assay Method & Results & Ref. \\
\hline $\begin{array}{l}\text { Apis mellifera venom } \\
\text { (compared to mellitin) }\end{array}$ & $\mathrm{n} / \mathrm{a}$ & $\begin{array}{l}\text { Borrelia burgdorferi strain B31 } \\
\text { (ATCC 35210) }\end{array}$ & $\begin{array}{l}\text { SYBR Green } \\
\text { I/Propidium Iodide } \\
\text { assay and biofilm } \\
\text { assay }\end{array}$ & $\begin{array}{l}\text { Both bee venom and mellitin } \\
\text { demonstrated good antimicrobial } \\
\text { activity against the free form of } B \text {. } \\
\text { burgdorferi and the biofilm-associated } \\
\text { form }\end{array}$ & [162] \\
\hline $\begin{array}{l}\text { Apis mellifera venom } \\
\text { (compared to mellitin) }\end{array}$ & Brazil & $\begin{array}{l}\text { S. aureus (ATCC 13565, ATCC } \\
\text { 14558, ATCC 19095, and ATCC } \\
\text { 23235, all Enterotoxigenic), } \\
\text { and five clinical isolates of } \\
\text { MRSA (recovered from } \\
\text { human specimens) }\end{array}$ & $\begin{array}{l}\text { The resazurin } \\
\text { microtiter assay } \\
\text { (REMA) }\end{array}$ & $\begin{array}{l}\text { Apitoxin and melittin yielded } \\
\text { antibacterial activity against MRSA } \\
\text { (MIC: } 7.2 \mu \mathrm{g} / \mathrm{mL} \text {, and } 6.7 \mu \mathrm{g} / \mathrm{mL} \text {, } \\
\text { respectively). Apitoxin and melittin had } \\
\text { no effect on the production of } \\
\text { enterotoxin and/or its release. }\end{array}$ & [212] \\
\hline $\begin{array}{l}\text { Apis mellifera venom } \\
\text { (commercial, freeze-dried) }\end{array}$ & $\mathrm{n} / \mathrm{a}$ & $\begin{array}{l}\text { Pseudomonas putida (ATCC } \\
700008), \text { Pseudomonas } \\
\text { fuorescens (NCIMB 9046) and } \\
\text { E. coli } \mathrm{K}-12, \mathrm{MG} 1655 \text { (ATCC } \\
47076),\end{array}$ & $\begin{array}{l}\text { In vitro viability assay } \\
\text { and biochemical } \\
\text { analysis }\end{array}$ & $\begin{array}{l}\text { Bee venom exerted its antibacterial } \\
\text { activities against the tested pathogens } \\
\text { via alteration in the membrane } \\
\text { permeability, destruction of bacterial cell } \\
\text { wall, cell contents leakage, and } \\
\text { inactivation of bacterial metabolic } \\
\text { activity leading to cell death }\end{array}$ & [213] \\
\hline $\begin{array}{l}\text { Apis mellifera venom } \\
\text { (apitoxin) }\end{array}$ & Ecuador & $\begin{array}{l}\text { Salmonella (CECT } 4395 \text { ) and } L . \\
\text { monocytogenes (CECT 934) and } \\
49 \text { S. enterica and } 7 \text { L. } \\
\text { monocytogenes strains } \\
\text { isolated from poultry products }\end{array}$ & $\begin{array}{l}\text { In vitro } \\
\text { (micro-dilution assay) }\end{array}$ & $\begin{array}{l}\text { Apitoxin is effective against foodborne } \\
\text { pathogens tested in the study (MIC } \\
\text { range: } 16-32 \mu \mathrm{g} / \mathrm{mL} \text { for L. monocytogenes } \\
\text { and } 256-1024 \mu \mathrm{g} / \mathrm{mL} \text { for } S \text {. enterica) }\end{array}$ & [214] \\
\hline
\end{tabular}

\section{Antiparasitic Potential of Bee Products}

Parasitic diseases are still among the most challenging public health issues in the countries with subtropical, tropical, and temperate climates [215-217]. One factor contributing to the spread of these infections is the lack of an effective and safe therapy. The current pharmacotherapy options are reported to have significant shortcomings such as being suboptimally active, especially towards the specific form of the parasites, have varying rates of efficacy, have burdensome side effects, need long treatment/administration terms, and the resistance to their action of some parasites [218-220]. Considering this scenario, there is a substantial need to find and promote new potent antiparasitic treatments which are affordable and have minimal adverse reactions.

In recent decades, there has been a keen interest in screening the pharmacological and chemical characteristics of bee-related products, a promising source of natural bioactive substances, as an alternative antiparasitic therapy [221]. Since classical times, bee related products have been popularly used traditionally as herbal remedies for treating some infectious diseases in many communities around the world [222]. In this review, we found that there are four bee-related products i.e., propolis, bee venom, bee pollen and honey that have been extensively studied to uncover their antiparasitic activities against protozoa and worms as the commonest classes of parasites infecting humans. Diverse studies have indicated that bee products are shown to be scientifically effective, via in vitro and/or in vivo tests, in treating a wide variety of infectious diseases such as schistosomiasis, trypanosomiasis (chagas disease), leishmaniasis, toxocariasis, plasmodiasis, toxoplasmosis, blastocystis infection, amebiasis, giardiasis, cryptosporidiosis, and echinococcosis (Table 3).

The curative properties of bee products have been directly associated to their chemical components. However, the chemical constituents of bee products are complex and differ according to their botanical source and geographical origins as indicated by the regional variations in the antiparasitic activities of the bee products [223-225]. Other factors reported to influence the dissimilarity of the physicochemical characteristics of the bee products are the vegetation surrounding the beehive, collection time, soil diversity, geoclimatic conditions or seasons in the collection area, the bee species, and particular flora living at the harvesting location [226-228]. Variations in the concentration of effective bee products are also predominantly affected by the type and origins of parasites used in 
the experiments as well as the preparation method $[198,229,230]$. There is a wide range of the extraction method applied to obtain, for example, propolis extracts ranging from conventional separation technique using organic solvent such as ethanol to a more sophisticated one such as a supercritical fluid extraction method [231]. The extraction methods can influence the amount of active substances in the extract and therefore, might change the biological activities of the extracts [231]. Lastly, the type of bee products also determines the magnitude of biological properties. Some studies indicated that different varieties of Brazilian propolis such as red, green, and brown have distinct chemical compounds and therefore, have a different potency against parasites parasitizing humans [198,232].

There are several proposed pharmacological mechanism of bee products to act against protozoan infections which are deemed to be facilitated by their flavonoid and phenolic constituents as follows [233-235]: (1) Activation of macrophages which kills the parasite via the production of ROS (particularly superoxide dismutase) and nitrogen metabolites [236,237]; (2) The alteration of angiogenesis in the affected tissue [236,238]; (3) Stimulation of immunomodulatory effects, by influencing the production of interferon- $\gamma$, tumor necrosis factor $\alpha$, IL-1, IL-4 and IL-17 [239-241]; (4) Induction of apoptosis-like mechanisms in parasites [236]; (5) Membrane disruption in parasites [242].

Table 3. Antiparasitic effect of selected bee products.

\begin{tabular}{|c|c|c|c|c|c|}
\hline Bee Products & Country & Parasites & $\begin{array}{l}\text { Assay } \\
\text { Method }\end{array}$ & Results & Refs. \\
\hline $\begin{array}{l}\text { Propolis extracts }(12 \\
\text { samples from different } \\
\text { location in Libya) }\end{array}$ & Libya & $\begin{array}{l}\text { Trypanosoma brucei (s427); } \\
\text { Leishmania donovani; Plasmodium } \\
\text { falciparum }\end{array}$ & In vitro & $\begin{array}{l}\text { All the extracts are to some extent effective } \\
\text { against all of the tested protozoa. There are } \\
\text { regional variations in the antiparasitic properties }\end{array}$ & [223] \\
\hline $\begin{array}{l}\text { Ethanolic extracts of } \\
\text { European propolis ( } 35 \\
\text { different samples) }\end{array}$ & Europe & $\begin{array}{l}\text { Trypanosoma brucei } 427 \mathrm{WT} \text {; } \\
\text { Trypanosoma brucei } \mathrm{B} 48 \text { (resistant } \\
\text { strain); Trypanosoma congolense; } \\
\text { Leishmania mexicana } \mathrm{WT} ; \\
\text { Leishmania mexicana } \mathrm{C} 12 \mathrm{Rx} \\
\text { (resistant strain) }\end{array}$ & In vitro & $\begin{array}{l}\text { All extracts display high level activities against } \\
\text { the parasites. Yet, there are regional variations in } \\
\text { the antiparasitic properties }\end{array}$ & {$[225]$} \\
\hline $\begin{array}{l}\text { Hydroethanolic red propolis } \\
\text { extracts }\end{array}$ & Brazil & $\begin{array}{l}\text { Trypanosoma cruzi; Leishmania } \\
\text { braziliensis vianna; Leishmania } \\
\text { infantum promastigotes }\end{array}$ & In vitro & $\begin{array}{l}\text { The extracts exhibit strong cytotoxic properties } \\
\text { against the protozoan parasites }\end{array}$ & [227] \\
\hline $\begin{array}{l}\text { Ethanolic extracts of red } \\
\text { propolis }\end{array}$ & Brazil & Schistosoma mansoni & $\begin{array}{l}\text { In vitro, } \\
\text { in vivo }\end{array}$ & $\begin{array}{l}\text { Propolis displays antischistosomal properties by } \\
\text { decreasing motility and producing: mortality of } \\
\text { adult parasites; morphological disruptions in the } \\
\text { schistosomes' tegument; and substantial } \\
\text { impairment in egg generation. Propolis also } \\
\text { significantly lower the worm and egg burden in } \\
\text { both early and chronic } S \text {. mansoni murine } \\
\text { infection model }\end{array}$ & [229] \\
\hline $\begin{array}{l}\text { Ethanolic extracts of red } \\
\text { propolis }\end{array}$ & Brazil & Trypanosoma cruzi & In vitro & $\begin{array}{l}\text { Ethanolic propolis extracts have high } \\
\text { inhibitory activity against T. cruzi }\end{array}$ & [198] \\
\hline $\begin{array}{l}\text { Dry, alcoholic, and glycolic } \\
\text { green } \\
\text { propolis extracts }\end{array}$ & Brazil & $\begin{array}{l}\text { Leishmania (Viannia) braziliensis } \\
\text { promastigotes and amastigotes }\end{array}$ & In vitro & $\begin{array}{l}\text { The extracts exhibits antileishmanial activity } \\
\text { against promastigotes and amastigotes stages of } \\
\text { the parasite }\end{array}$ & [237] \\
\hline $\begin{array}{l}\text { Ethanolic extracts of red and } \\
\text { green propolis }\end{array}$ & Brazil & Leishmania (Vianna) braziliensis & n.a & $\begin{array}{l}\text { Both propolis extracts exhibits leishmanicidal } \\
\text { effect in a dose-dependent manner. Yet, the red } \\
\text { propolis extract displays a higher efficacy than } \\
\text { the green extract }\end{array}$ & {$[231]$} \\
\hline $\begin{array}{l}\text { Hydroethanolic extract of } \\
\text { red propolis }\end{array}$ & Brazil & $\begin{array}{l}\text { Leishmania chagasi promastigote; } \\
\text { Leishmania amazonensis } \\
\text { promastigote }\end{array}$ & In vitro & $\begin{array}{l}\text { The extract exhibits leishmanicidal potency } \\
\text { againts the parasites }\end{array}$ & {$[243]$} \\
\hline $\begin{array}{l}\text { Hydroalcoholic extract of } \\
\text { Brazilian propolis }\end{array}$ & Brazil & Leishmania (Viannia) braziliensis & In vitro & $\begin{array}{l}\text { Propolis extract shows immunomodulatory } \\
\text { effects, by enhancing IL- } 4 \text { and IL- } 17 \text { and lowering } \\
\text { IL-10, and therefore, may protect against } \\
\text { Leishmania infection and clear the parasite }\end{array}$ & [239] \\
\hline
\end{tabular}


Table 3. Cont

\begin{tabular}{|c|c|c|c|c|c|}
\hline Bee Products & Country & Parasites & $\begin{array}{l}\text { Assay } \\
\text { Method }\end{array}$ & Results & Refs. \\
\hline $\begin{array}{l}\text { Hydroalcoholic extract of } \\
\text { Brazilian green propolis }\end{array}$ & Brazil & $\begin{array}{l}\text { Leishmania amazonensis } \\
\text { promastigotes and amastigotes }\end{array}$ & $\begin{array}{l}\text { In vitro } \\
\text { In vivo }\end{array}$ & $\begin{array}{l}\text { Propolis extract decreases the viability of } L \text {. } \\
\text { amazonensis amastigotes and promastigotes. The } \\
\text { extract also decreases the parasites and } \\
\text { stimulates the macrophage recruitment into the } \\
\text { lesion caused by the L. amazonensis }\end{array}$ & [236] \\
\hline $\begin{array}{l}\text { Degradation products of } \\
\text { major compounds of green } \\
\text { propolis: Z-artepillin C and } \\
\text { Z-p-coumaric Acid }\end{array}$ & Brazil & $\begin{array}{l}\text { Leishmania amazonensis } \\
\text { promastigotes and amastigotes }\end{array}$ & In vitro & $\begin{array}{l}\text { Both Z-artepillin C and Z-p-coumaric acid } \\
\text { display a promising and significant activity } \\
\text { against L. amazonensis }\end{array}$ & [244] \\
\hline $\begin{array}{l}\text { Hydroalcoholic extract of } \\
\text { Melipona fasciculata } \\
\text { geopropolis }\end{array}$ & Brazil & $\begin{array}{l}\text { Leishmania amazonensis } \\
\text { promastigotes and amastigotes }\end{array}$ & In vitro & $\begin{array}{l}\text { Geopropolis has an antileishmanial effect and } \\
\text { effective in reducing the number of the } L \text {. } \\
\text { amazonensis promastigotes and amastigotes }\end{array}$ & [233] \\
\hline $\begin{array}{l}\text { Isolated compound of Bee } \\
\text { pollen monofloral }\end{array}$ & Brazil & Leishmania amazonensis & In vitro & $\begin{array}{l}\text { The isolated compound identified as the } \\
\text { biflavonoid rhusflavone shows high } \\
\text { antileishmanial effect against L. amazonensis } \\
\text { promastigotes and amastigotes }\end{array}$ & [234] \\
\hline Bee venom and propolis & Egypt & Schistosoma mansoni & In vivo & $\begin{array}{l}\text { Bee venom and propolis exerts anti-schistosomal } \\
\text { activities by substantially lowering the mean } \\
\text { total numbers of worm, mean values of } \\
\text { immature and mature egg as well as the ova } \\
\text { count in hepatic tissue }\end{array}$ & [245] \\
\hline $\begin{array}{l}\text { Egyptian propolis ethanolic } \\
\text { extract }\end{array}$ & Egypt & Toxocara vitulorum & In vitro & $\begin{array}{l}\text { The extract exhibits anthelmintic efficacy and the } \\
\text { nematicidal effect is dose-dependent }\end{array}$ & [246] \\
\hline $\begin{array}{l}\text { Egyptian propolis ethanolic } \\
\text { extract }\end{array}$ & Egypt & Blastocystis spp. & In vitro & $\begin{array}{l}\text { The extract presents a notable obstructive effect } \\
\text { on the growth of Blastocystis parasites }\end{array}$ & [247] \\
\hline $\begin{array}{l}\text { Egyptian propolis ethanolic } \\
\text { and water extract }\end{array}$ & Egypt & Cryptosporidium spp. & In vivo & $\begin{array}{l}\text { The prophylactic and therapeutic administration } \\
\text { of the extracts moderately effective in reducing } \\
\text { the oocysts shedding on cryptosporidiosis } \\
\text { infected rats }\end{array}$ & [248] \\
\hline $\begin{array}{l}\text { Egyptian propolis ethanolic } \\
\text { extract }\end{array}$ & Egypt & Toxoplasma gondii & In vivo & $\begin{array}{l}\text { Propolis markedly decreases the amount of IL- } 1 \beta \text {, } \\
\text { IL-6, and TNF } \alpha \text { in T. gondii infected models }\end{array}$ & [249] \\
\hline $\begin{array}{l}\text { Egyptian propolis ethanolic } \\
\text { extract }\end{array}$ & Egypt & Giardia lamblia & In vivo & $\begin{array}{l}\text { Propolis markedly reduce the G. lamblia } \\
\text { trophozoites count }\end{array}$ & [250] \\
\hline $\begin{array}{l}\text { Ziziphus spina-christi honey; } \\
\text { Acacia nilotca honey; Acacia } \\
\text { seyal honey; Cucurbita } \\
\text { maxima honey }\end{array}$ & Saudi Arabia & $\begin{array}{l}\text { Entamoeba histolytica; Giardia } \\
\text { lamblia }\end{array}$ & In vitro & $\begin{array}{l}\text { All honeys are potentially effective to be used as } \\
\text { antiamoebic and antigiardial agents since they } \\
\text { can halt the growth of the trophozoites }\end{array}$ & [47] \\
\hline $\begin{array}{l}\text { Ethanolic extraction of } \\
\text { Saudi propolis }\end{array}$ & Saudi Arabia & Trypanosoma brucei & In vitro & $\begin{array}{l}\text { The extract indicates a significant } \\
\text { anti-trypanosomal activity }\end{array}$ & [251] \\
\hline Capparis spinosa honey & Saudi Arabia & Toxoplasma gondii & In vivo & $\begin{array}{l}\text { Honey elevates the amount of antibody titer and } \\
\text { the cytokines (IFN- } \gamma \text {, IL-1, and IL-6) in T. gondii } \\
\text { infected rats }\end{array}$ & [241] \\
\hline $\begin{array}{l}\text { Ethanol and } \\
\text { dichloromethane Propolis } \\
\text { extracts }\end{array}$ & Iran & Plasmodium falciparum & In vitro & $\begin{array}{l}\text { All extracts show concentration-dependent } \\
\text { anti-plasmodial activity. Dichloromethane } \\
\text { extract has the most potent inhibitory effect }\end{array}$ & [252] \\
\hline Ethanolic extract of propolis & Iran & Leishmania major & $\begin{array}{l}\text { In vitro, } \\
\text { In vivo }\end{array}$ & $\begin{array}{l}\text { Both tests indicate that the extract has an } \\
\text { effective antileishmanial activity against } L \text {. major. } \\
\text { The extract reduces the number of promastigotes } \\
\text { and decreases the size of ulcers significantly }\end{array}$ & [253] \\
\hline $\begin{array}{l}\text { Ethanolic extract of algerian } \\
\text { propolis }\end{array}$ & Algeria & Echinococcus granulosus & $\begin{array}{l}\text { In vitro, } \\
\text { In vivo }\end{array}$ & $\begin{array}{l}\text { Both tests indicate that the extract is an effective } \\
\text { antihydatic scolicidal effect since it has a major } \\
\text { scolicidal activity against } E \text {. granulosus at all } \\
\text { tested concentration and reduces cystic } \\
\text { echinococcosis development in in vivo model }\end{array}$ & [254] \\
\hline $\begin{array}{l}\text { Methanolic extracts of } \\
\text { propolis (ten different } \\
\text { propolis from different } \\
\text { geographical area in Bolivia) }\end{array}$ & Bolivia & $\begin{array}{l}\text { Leishmania amazonensis; Leishmania } \\
\text { braziliensis }\end{array}$ & In vitro & $\begin{array}{l}\text { All propolis extracts show growth inhibition } \\
\text { against both protozoa. Propolis with rich } \\
\text { phenolic contents shows the best antiprotozoal } \\
\text { effect }\end{array}$ & [255] \\
\hline
\end{tabular}


Table 3. Cont.

\begin{tabular}{|c|c|c|c|c|c|}
\hline Bee Products & Country & Parasites & $\begin{array}{l}\text { Assay } \\
\text { Method }\end{array}$ & Results & Refs. \\
\hline $\begin{array}{l}\text { Methanolic extracts of } \\
\text { propolis (three different } \\
\text { propolis from different } \\
\text { geographical area in } \\
\text { Ecuador) }\end{array}$ & Ecuador & Leishmania amazonensis & In vitro & $\begin{array}{l}\text { All propolis extracts show growth inhibition } \\
\text { against the protozoa. Propolis with the richest } \\
\text { flavonoids contents shows the best antiprotozoal } \\
\text { effect }\end{array}$ & [235] \\
\hline $\begin{array}{l}\text { Ethanolic extracts of } \\
\text { propolis (twelve different } \\
\text { propolis from eight different } \\
\text { geographical area in } \\
\text { Nigeria) }\end{array}$ & Nigeria & $\begin{array}{l}\text { Trypanosoma brucei (s427, } \\
\text { wild-type); Trypanosoma brucei } \\
\text { (B48, resistant strain); Trypanosoma } \\
\text { brucei (aqp2/aqp3 null, resistant } \\
\text { strain) }\end{array}$ & In vitro & $\begin{array}{l}\text { The extracts are active against all the tested } \\
\text { parasites }\end{array}$ & [224] \\
\hline $\begin{array}{l}\text { Isolated phenolic } \\
\text { compounds of Nigerian red } \\
\text { propolis }\end{array}$ & Nigeria & $\begin{array}{l}\text { Trypanosoma brucei (s427, } \\
\text { wild-type); Trypanosoma brucei } \\
\text { (B48, resistant strain); Trypanosoma } \\
\text { brucei (aqp2/aqp3 null, resistant } \\
\text { strain) }\end{array}$ & In vitro & $\begin{array}{l}\text { The extract displays moderate to high } \\
\text { antitrypanosomal effectivity against all the tested } \\
\text { parasites }\end{array}$ & [256] \\
\hline $\begin{array}{l}\text { Tanzanian propolis } \\
\text { ethanolic extract }\end{array}$ & Tanzania & $\begin{array}{l}\text { Trypanosoma brucei (s } 427, \\
\text { wild-type); Trypanosoma brucei } \\
\text { (B48, resistant strain) }\end{array}$ & In vitro & $\begin{array}{l}\text { The extract displays antitrypanosomal potency } \\
\text { against both parasites }\end{array}$ & [257] \\
\hline $\begin{array}{l}\text { Zambian propolis ethanolic } \\
\text { extract }\end{array}$ & Zambia & $\begin{array}{l}\text { Trypanosoma brucei (s } 427, \\
\text { wild-type); Trypanosoma brucei } \\
\text { (B48, resistant strain) }\end{array}$ & In vitro & $\begin{array}{l}\text { The extract displays antitrypanosomal activity } \\
\text { against the wild type of } T \text {. brucei and the } \\
\text { multi-drug resistant clone }\end{array}$ & [257] \\
\hline
\end{tabular}

\section{Bee Product-Derived Nanoparticles as Potential Therapeutic Agents}

Green chemistry principles have recently received much attention for their use in creating biocompatible nanomaterials. Due to the presence of phytoconstituents as stabilizing ligands on their surfaces, nanoparticles prepared by the application of natural product extracts have frequently demonstrated promising bioactivity. Honey bee products such as honey, royal jelly, bee venom, pollen, and beeswax are thought to be promising sources of products to avoid nanoparticle aggregation thus improving the biocompatibility, stability, and biological application. It is possible to functionalize these nanomaterial biomolecules. Metal nanoparticles such as platinum, gold, silver, zinc and others are commonly used nanoparticles in the biomedicine sector. The bactericidal and inhibitory properties of Ag NPs-based nanoparticles against various microbes are quite impressive, along with their high efficiency, strong biocompatibility, easy availability, and low cost which, made them gain significant consideration to scientists and technologists [258].

Al-Yousef et al. prepared Ag NPs (AgNPs-G) using bee pollen aqueous extract as a bioreductant during the experiments and found that they demonstrated excellent antioxidant properties and worked against different Gram-positive and negative bacteria. They even successfully exerted an anti-proliferative effect against cancer cell lines, including MCF-7 and HepG2 [259]. Magnetite nanoparticles are another type of nanoparticle with antimicrobial properties. According to El-Guendouz et al. magnetite nanoparticles twinned with propolis shows antimicrobial activities against methicillin-resistant strains of S. aureus [260]. Honey is another bee product that has antimicrobial, anti-inflammatory, and antioxidant properties. Chen et al. reported a new bioactive component-vesicle-like nanoparticles (H-VLNs) in honey that shows anti-inflammatory activities [261]. H-VLNs can disrupt a crucial inflammatory signaling platform in the innate immune system by restraining the formation and activation of the nucleotide-binding domain and pyrin domain-containing 3 (NLRP3) inflammasome. In mice, these nanoparticles reduced inflammation and liver damage in an experimentally induced acute liver injury model [261].

Like metal nanoparticles, polymeric nanoparticles and liposomes are other types of nanoparticles that are a popular choice as drug delivery vehicles for therapeutic applications in the pharmaceutical area and are safe. A study conducted by Iadnut et al. concluded that ethanolic extract of propolis loaded with polymeric nanoparticles pro- 
foundly inhibited the growth of Candida albicans [262]. They found that the ethanolic extract of propolis-loaded poly(lactic-co-glycolic acid) nanoparticles can reduce gene-encoding virulence-associated hyphal adhesion proteins of $C$. albicans, which further attenuates the fungal virulence [262]. In another study, do Nascimento et al. investigated the immunosuppressive activity of "multiple-constituent extract in the co-delivery system" against leishmaniasis by loading using Brazilian red propolis extract into polymeric nanoparticles [263]. Various dosage forms of red propolis extract loaded with nanoparticles were tested and discovered to be a potential intermediate product for the preparation of various drugs for diseases like leishmaniasis.

Bee venom is gaining popularity for its antipathogenic, anticancer, anti-tumor activities. Alalawy et al. prepared fungal chitosan nanoparticles loaded with bee venom and demonstrated that such bee-venom nanoparticle preparation was significantly potent as a natural anti-proliferative agent against cervical cancer [28]. In addition to that, Saber et al. used bee venom loaded with chitosan to successfully treat amoebiasis in mice [264], indicating that, bee venom possesses antiparasitic properties in addition to its anticancer properties.

\section{Concluding Remarks and Future Directions}

Bee products such as honey, propolis, bee pollen, royal jelly, beebread, beeswax, and bee venom have been broadly used in traditional healing practices. With their potential medical and pharmaceutical properties, increasing interest in bee products has been seen in the last century. With the advancements in research tools and our great progress in the understanding of biological processes, the main active component(s) responsible for the anticancer, antibacterial, antiviral as well as antiparasitic properties of bee products need to be clearly elucidated in a standardized way in order to improve the application of bee products in disease management. The issue of standardization has also been hampering the use of bee products not only in pharmaceuticals but also in cosmetics and food industries. Furthermore, there is also a need to determine the optimal dose of bee products and how to use the products to treat cancer as well as infections. This information is substantial in order to bridge the experimental results from the bench to the bedside.

Author Contributions: Conceptualization, F.N., T.B.E., J.S.-G.; methodology, investigation, resources, F.N., A.M., M.A.B., M.R., T.B.E. and J.S.-G.; writing—original draft preparation, F.N., A.M., M.A.B., M.R., S.R.P., S.M., T.B.E. and J.S.-G.; together with writing-review \& editing, correspondence, F.N., T.B.E. and J.S.-G. All authors have read and agreed to the published version of the manuscript.

Funding: This research received no external funding.

Institutional Review Board Statement: Not applicable.

Informed Consent Statement: Not applicable.

Data Availability Statement: Available data are presented in the manuscript.

Conflicts of Interest: The authors declare no conflict of interest.

\section{References}

1. Samarghandian, S.; Farkhondeh, T.; Samini, F. Honey and Health: A Review of Recent Clinical Research. Pharmacogn. Res. 2017, 9, 121-127. [CrossRef]

2. Al-Hatamleh, M.A.I.; Boer, J.C.; Wilson, K.L.; Plebanski, M.; Mohamud, R.; Mustafa, M.Z. Antioxidant-Based Medicinal Properties of Stingless Bee Products: Recent Progress and Future Directions. Biomolecules 2020, 10, 923. [CrossRef]

3. Cornara, L.; Biagi, M.; Xiao, J.; Burlando, B. Therapeutic Properties of Bioactive Compounds from Different Honeybee Products. Front. Pharm. 2017, 8, 412. [CrossRef]

4. Sung, H.; Ferlay, J.; Siegel, R.L.; Laversanne, M.; Soerjomataram, I.; Jemal, A.; Bray, F. Global Cancer Statistics 2020: GLOBOCAN Estimates of Incidence and Mortality Worldwide for 36 Cancers in 185 Countries. CA Cancer J. Clin. 2021, 71, 209-249. [CrossRef]

5. Münstedt, K.; Männle, H. Bee products and their role in cancer prevention and treatment. Complement. Ther. Med. 2020, 51, 102390. [CrossRef]

6. Afrin, S.; Haneefa, S.M.; Fernandez-Cabezudo, M.J.; Giampieri, F.; Al-Ramadi, B.K.; Battino, M. Therapeutic and preventive properties of honey and its bioactive compounds in cancer: An evidence-based review. Nutr. Res. Rev. 2020, 33, 50-76. [CrossRef] 
7. Rady, I.; Siddiqui, I.A.; Rady, M.; Mukhtar, H. Melittin, a major peptide component of bee venom, and its conjugates in cancer therapy. Cancer Lett. 2017, 402, 16-31. [CrossRef]

8. Kurek-Górecka, A.; Górecki, M.; Rzepecka-Stojko, A.; Balwierz, R.; Stojko, J. Bee Products in Dermatology and Skin Care. Molecules 2020, 25, 556. [CrossRef]

9. Meo, S.A.; Al-Asiri, S.A.; Mahesar, A.L.; Ansari, M.J. Role of honey in modern medicine. Saudi J. Biol. Sci. 2017, 24, 975-978. [CrossRef]

10. Anjum, S.I.; Ullah, A.; Khan, K.A.; Attaullah, M.; Khan, H.; Ali, H.; Bashir, M.A.; Tahir, M.; Ansari, M.J.; Ghramh, H.A.; et al. Composition and functional properties of propolis (bee glue): A review. Saudi J. Biol. Sci. 2019, 26, 1695-1703. [CrossRef]

11. Yildirim, A.; Duran, G.G.; Duran, N.; Jenedi, K.; Bolgul, B.S.; Miraloglu, M.; Muz, M. Antiviral Activity of Hatay Propolis Against Replication of Herpes Simplex Virus Type 1 and Type 2. Med. Sci. Monit. 2016, 22, 422-430. [CrossRef]

12. Münstedt, K. Bee products and the treatment of blister-like lesions around the mouth, skin and genitalia caused by herpes viruses-A systematic review. Complement. Med. 2019, 43, 81-84. [CrossRef]

13. Watanabe, K.; Rahmasari, R.; Matsunaga, A.; Haruyama, T.; Kobayashi, N. Anti-influenza Viral Effects of Honey In Vitro: Potent High Activity of Manuka Honey. Arch. Med. Res. 2014, 45, 359-365. [CrossRef]

14. Zareie, P.P. Honey as an Antiviral Agent against Respiratory Syncytial Virus. Ph.D. Dissertation, University of Waikato, Waikato, New Zealand, 2011.

15. Amoros, M.; Lurton, E.; Boustie, J.; Girre, L.; Sauvager, F.; Cormier, M. Comparison of the anti-herpes simplex virus activities of propolis and 3-methyl-but-2-enyl caffeate. J. Nat. Prod. 1994, 57, 644-647. [CrossRef] [PubMed]

16. Serkedjieva, J.; Manolova, N.; Bankova, V. Anti-influenza virus effect of some propolis constituents and their analogues (esters of substituted cinnamic acids). J. Nat. Prod. 1992, 55, 294-302. [CrossRef]

17. Shimizu, T.; Hino, A.; Tsutsumi, A.; Park, Y.K.; Watanabe, W.; Kurokawa, M. Anti-Influenza Virus Activity of Propolis in Vitro and its Efficacy against Influenza Infection in Mice. Antivir. Chem. Chemother. 2008, 19, 7-13. [CrossRef]

18. Governa, P.; Cusi, M.G.; Borgonetti, V.; Sforcin, J.M.; Terrosi, C.; Baini, G.; Miraldi, E.; Biagi, M. Beyond the Biological Effect of a Chemically Characterized Poplar Propolis: Antibacterial and Antiviral Activity and Comparison with Flurbiprofen in Cytokines Release by LPS-Stimulated Human Mononuclear Cells. Biomedicines 2019, 7, 73. [CrossRef]

19. Ito, J.; Chang, F.-R.; Wang, H.-K.; Park, Y.K.; Ikegaki, M.; Kilgore, N.; Lee, K.-H. Anti-AIDS Agents. 48. Anti-HIV Activity of Moronic Acid Derivatives and the New Melliferone-Related Triterpenoid Isolated from Brazilian Propolis. J. Nat. Prod. 2001, 64, 1278-1281. [CrossRef]

20. Shvarzbeyn, J.; Huleihel, M. Effect of propolis and caffeic acid phenethyl ester (CAPE) on NFkB activation by HTLV-1 Tax. Antivir Res. 2011, 90, 108-115. [CrossRef]

21. El-Hadya, F.K.A.; Hegazi, A.G.; Wollenweber, E. Effect of Egyptian Propolis on the Susceptibility of LDL to Oxidative Modification and its Antiviral Activity with Special Emphasis on Chemical Composition. Z. Für. Nat. C 2007, 62, 645-655. [CrossRef]

22. Takeshita, T.; Watanabe, W.; Toyama, S.; Hayashi, Y.; Honda, S.; Sakamoto, S.; Matsuoka, S.; Yoshida, H.; Takeda, S.; Hidaka, M.; et al. Effect of Brazilian Propolis on Exacerbation of Respiratory Syncytial Virus Infection in Mice Exposed to Tetrabromobisphenol A, a Brominated Flame Retardant. Evid. Based Complement. Altern. Med. 2013, 2013, 698206. [CrossRef]

23. Búfalo, M.C.; Figueiredo, A.S.; de Sousa, J.P.; Candeias, J.M.; Bastos, J.K.; Sforcin, J.M. Anti-poliovirus activity of Baccharis dracunculifolia and propolis by cell viability determination and real-time PCR. J. Appl. Microbiol. 2009, 107, 1669-1680. [CrossRef] [PubMed]

24. Soroy, L.; Bagus, S.; Yongkie, I.P.; Djoko, W. The effect of a unique propolis compound (Propoelix ${ }^{\mathrm{TM}}$ ) on clinical outcomes in patients with dengue hemorrhagic fever. Infect. Drug Resist. 2014, 7, 323-329. [CrossRef]

25. Lyu, S.Y.; Rhim, J.Y.; Park, W.B. Antiherpetic activities of flavonoids against herpes simplex virus type 1 (HSV-1) and type 2 (HSV-2) in vitro. Arch. Pharm. Res. 2005, 28, 1293-1301. [CrossRef]

26. Lee, I.K.; Hwang, B.S.; Kim, D.W.; Kim, J.Y.; Woo, E.E.; Lee, Y.J.; Choi, H.J.; Yun, B.S. Characterization of Neuraminidase Inhibitors in Korean Papaver rhoeas Bee Pollen Contributing to Anti-Influenza Activities In Vitro. Planta Med. 2016, 82, 524-529. [CrossRef]

27. Lima, W.G.; Brito, J.C.M.; da Cruz Nizer, W.S. Bee products as a source of promising therapeutic and chemoprophylaxis strategies against COVID-19 (SARS-CoV-2). Phytother. Res. 2021, 35, 743-750. [CrossRef]

28. Santos-Buelga, C.; González-Paramás, A.M. Phenolic Composition of Propolis. In Bee Products—Chemical and Biological Properties; Alvarez-Suarez, J.M., Ed.; Springer International Publishing: Cham, Switzerland, 2017; pp. 99-111. [CrossRef]

29. Mohammed, S.E.A.; Kabashi, A.S.; Koko, W.S.; Azim, M.K. Antigiardial activity of glycoproteins and glycopeptides from Ziziphus honey. Nat. Prod. Res. 2015, 29, 2100-2102. [CrossRef]

30. Svečnjak, L.; Chesson, L.A.; Gallina, A.; Maia, M.; Martinello, M.; Mutinelli, F.; Muz, M.N.; Nunes, F.M.; Saucy, F.; Tipple, B.J.; et al. Standard methods for Apis mellifera beeswax research. J. Apic. Res. 2019, 58, 1-108. [CrossRef]

31. Fratini, F.; Cilia, G.; Turchi, B.; Felicioli, A. Beeswax: A minireview of its antimicrobial activity and its application in medicine. Asian Pac. J. Trop. Med. 2016, 9, 839-843. [CrossRef]

32. Ratiu, I.A.; Al-Suod, H.; Bukowska, M.; Ligor, M.; Buszewski, B. Correlation Study of Honey Regarding their Physicochemical Properties and Sugars and Cyclitols Content. Molecules 2020, 25, 34. [CrossRef]

33. De-Melo, A.A.M.; de Almeida-Muradian, L.B. Chemical Composition of Bee Pollen. In Bee Products-Chemical and Biological Properties; Alvarez-Suarez, J.M., Ed.; Springer International Publishing: Cham, Switzerland, 2017; pp. 221-259. [CrossRef] 
34. Viuda-Martos, M.; Pérez-Alvarez, J.A.; Fernández-López, J. Royal Jelly: Health Benefits and Uses in Medicine. In Bee ProductsChemical and Biological Properties; Alvarez-Suarez, J.M., Ed.; Springer International Publishing: Cham, Switzerland, 2017; pp. 199-218. [CrossRef]

35. Siheri, W.; Alenezi, S.; Tusiimire, J.; Watson, D.G. The Chemical and Biological Properties of Propolis. In Bee Products-Chemical and Biological Properties; Alvarez-Suarez, J.M., Ed.; Springer International Publishing: Cham, Switzerland, 2017; pp. 137-178. [CrossRef]

36. Abd El-Wahed, A.A.; Khalifa, S.A.M.; Sheikh, B.Y.; Farag, M.A.; Saeed, A.; Larik, F.A.; Koca-Caliskan, U.; AlAjmi, M.F.; Hassan, M.; Wahabi, H.A.; et al. Bee Venom Composition: From Chemistry to Biological Activity. In Studies in Natural Products Chemistry; Atta ur, R., Ed.; Elsevier: Amsterdam, The Netherlands, 2019; Volume 60, pp. 459-484.

37. Hassan, M.I.; Mohamed, A.F.; Amer, M.A.; Hammad, K.M.; Riad, S.A. Monitoring of the antiviral potential of bee venom and wax extracts against Adeno-7 (DNA) and Rift Valley fever virus (RNA) viruses models. J. Egypt Soc. Parasitol. 2015, 45, 193-198. [CrossRef] [PubMed]

38. Uddin, M.B.; Lee, B.H.; Nikapitiya, C.; Kim, J.H.; Kim, T.H.; Lee, H.C.; Kim, C.G.; Lee, J.S.; Kim, C.J. Inhibitory effects of bee venom and its components against viruses in vitro and in vivo. J. Microbiol. 2016, 54, 853-866. [CrossRef] [PubMed]

39. Aw Yong, P.Y.; Islam, F.; Harith, H.H.; Israf, D.A.; Tan, J.W.; Tham, C.L. The Potential use of Honey as a Remedy for Allergic Diseases: A Mini Review. Front. Pharm. 2020, 11, 599080. [CrossRef] [PubMed]

40. Santos-Buelga, C.; González-Paramás, A.M. Chemical Composition of Honey. In Bee Products-Chemical and Biological Properties; Alvarez-Suarez, J.M., Ed.; Springer International Publishing: Cham, Switzerland, 2017; pp. 43-82. [CrossRef]

41. Gündoğdu, E.; Cakmakci, S.; Şat, İ. An Overview of Honey: Its Composition, Nutritional and Functional Properties. J. Food Sci. Eng. 2019, 9, 10-14. [CrossRef]

42. Sousa, J.M.; de Souza, E.L.; Marques, G.; Meireles, B.; de Magalhães Cordeiro, Â.T.; Gullón, B.; Pintado, M.M.; Magnani, M. Polyphenolic profile and antioxidant and antibacterial activities of monofloral honeys produced by Meliponini in the Brazilian semiarid region. Food Res. Int. 2016, 84, 61-68. [CrossRef]

43. Ahmed, S.; Sulaiman, S.A.; Baig, A.A.; Ibrahim, M.; Liaqat, S.; Fatima, S.; Jabeen, S.; Shamim, N.; Othman, N.H. Honey as a Potential Natural Antioxidant Medicine: An Insight into Its Molecular Mechanisms of Action. Oxid. Med. Cell Longev. 2018, 2018, 8367846. [CrossRef]

44. Alqarni, A.S.; Owayss, A.A.; Mahmoud, A.A.; Hannan, M.A. Mineral content and physical properties of local and imported honeys in Saudi Arabia. J. Saudi Chem. Soc. 2014, 18, 618-625. [CrossRef]

45. Rao, P.V.; Krishnan, K.T.; Salleh, N.; Gan, S.H. Biological and therapeutic effects of honey produced by honey bees and stingless bees: A comparative review. Rev. Bras. De Farmacogn. 2016, 26, 657-664. [CrossRef]

46. Piszcz, P.; Głód, B.K. Antioxidative Properties of Selected Polish Honeys. J. Apic. Sci. 2019, 63, 81-91. [CrossRef]

47. Mohammed, S.E.A.; Kabbashi, A.S.; Koko, W.S.; Ansari, M.J.; Adgaba, N.; Al-Ghamdi, A. In vitro activity of some natural honeys against Entamoeba histolytica and Giardia lamblia trophozoites. Saudi J. Biol. Sci. 2019, 26, 238-243. [CrossRef]

48. Kocot, J.; Kiełczykowska, M.; Luchowska-Kocot, D.; Kurzepa, J.; Musik, I. Antioxidant Potential of Propolis, Bee Pollen, and Royal Jelly: Possible Medical Application. Oxid. Med. Cell. Longev. 2018, 2018, 7074209. [CrossRef]

49. Pasupuleti, V.R.; Sammugam, L.; Ramesh, N.; Gan, S.H. Honey, Propolis, and Royal Jelly: A Comprehensive Review of Their Biological Actions and Health Benefits. Oxid. Med. Cell Longev. 2017, 2017, 1259510. [CrossRef]

50. Bonamigo, T.; Campos, J.F.; Alfredo, T.M.; Balestieri, J.B.P.; Cardoso, C.A.L.; Paredes-Gamero, E.J.; de Picoli Souza, K.; dos Santos, E.L. Antioxidant, Cytotoxic, and Toxic Activities of Propolis from Two Native Bees in Brazil: Scaptotrigona depilis and Melipona quadrifasciata anthidioides. Oxid. Med. Cell. Longev. 2017, 2017, 1038153. [CrossRef] [PubMed]

51. Huang, S.; Zhang, C.P.; Wang, K.; Li, G.Q.; Hu, F.L. Recent advances in the chemical composition of propolis. Molecules 2014, 19, 9610. [CrossRef]

52. Hashem, N.M.; Hassanein, E.M.; Simal-Gandara, J. Improving Reproductive Performance and Health of Mammals Using Honeybee Products. Antioxidants 2021, 10, 336. [CrossRef] [PubMed]

53. Wang, X.; Sankarapandian, K.; Cheng, Y.; Woo, S.O.; Kwon, H.W.; Perumalsamy, H.; Ahn, Y.-J. Relationship between total phenolic contents and biological properties of propolis from 20 different regions in South Korea. BMC Complement. Altern. Med. 2016, 16, 65. [CrossRef]

54. El-Seedi, H.R.; Khalifa, S.A.M.; El-Wahed, A.A.; Gao, R.; Guo, Z.; Tahir, H.E.; Zhao, C.; Du, M.; Farag, M.A.; Musharraf, S.G.; et al. Honeybee products: An updated review of neurological actions. Trends Food Sci. Technol. 2020, 101, 17-27. [CrossRef]

55. Takashima, M.; Ichihara, K.; Hirata, Y. Neuroprotective effects of Brazilian green propolis on oxytosis/ferroptosis in mouse hippocampal HT22 cells. Food Chem. Toxicol. 2019, 132, 110669. [CrossRef]

56. Berretta, A.A.; Silveira, M.A.D.; Cóndor Capcha, J.M.; De Jong, D. Propolis and its potential against SARS-CoV-2 infection mechanisms and COVID-19 disease. Biomed. Pharmacother. 2020, 131, 110622. [CrossRef]

57. Vasconcelos, M.R.D.S.; Duarte, A.W.F.; Gomes, E.P.; Silva, S.C.D.; López, A.M.Q. Physicochemical composition and antioxidant potential of bee pollen from different botanical sources in Alagoas, Brazil. Ciência E Agrotecnologia 2017, 41, 447-458. [CrossRef]

58. Thakur, M.; Nanda, V. Composition and functionality of bee pollen: A review. Trends Food Sci. Technol. 2020, 98, 82-106. [CrossRef]

59. Gardana, C.; Del Bo', C.; Quicazán, M.C.; Corrrea, A.R.; Simonetti, P. Nutrients, phytochemicals and botanical origin of commercial bee pollen from different geographical areas. J. Food Compos. Anal. 2018, 73, 29-38. [CrossRef] 
60. Komosinska-Vassev, K.; Olczyk, P.; Kaźmierczak, J.; Mencner, L.; Olczyk, K. Bee pollen: Chemical composition and therapeutic application. Evid Based Complement. Altern. Med. 2015, 2015, 297425. [CrossRef] [PubMed]

61. Abdelnour, S.A.; Abd El-Hack, M.E.; Alagawany, M.; Farag, M.R.; Elnesr, S.S. Beneficial impacts of bee pollen in animal production, reproduction and health. J. Anim. Physiol. Anim. Nutr. 2019, 103, 477-484. [CrossRef] [PubMed]

62. Li, Q.-Q.; Wang, K.; Marcucci, M.C.; Sawaya, A.C.H.F.; Hu, L.; Xue, X.-F.; Wu, L.-M.; Hu, F.-L. Nutrient-rich bee pollen: A treasure trove of active natural metabolites. J. Funct. Foods 2018, 49, 472-484. [CrossRef]

63. Dong, X.; Zhou, Z.; Wang, L.; Saremi, B.; Helmbrecht, A.; Wang, Z.; Loor, J.J. Increasing the availability of threonine, isoleucine, valine, and leucine relative to lysine while maintaining an ideal ratio of lysine:methionine alters mammary cellular metabolites, mammalian target of rapamycin signaling, and gene transcription. J. Dairy Sci 2018, 101, 5502-5514. [CrossRef] [PubMed]

64. Dong, J.; Yang, Y.; Wang, X.; Zhang, H. Fatty acid profiles of 20 species of monofloral bee pollen from China. J. Apic. Res. 2015, 54, 503-511. [CrossRef]

65. Kostić, A.Ž.; Milinčić, D.D.; Gašić, U.M.; Nedić, N.; Stanojević, S.P.; Tešić, Ž.L.; Pešić, M.B. Polyphenolic profile and antioxidant properties of bee-collected pollen from sunflower (Helianthus annuus L.) plant. LWT 2019, 112, 108244. [CrossRef]

66. Sousa, C.; Andrade, P.B.; Valentão, P. Relationships of Echium plantagineum L. bee pollen, dietary flavonoids and their colonic metabolites with cytochrome P450 enzymes and oxidative stress. RSC Adv. 2016, 6, 6084-6092. [CrossRef]

67. Sattler, J.A.G.; de Melo, I.L.P.; Granato, D.; Araújo, E.; da Silva de Freitas, A.; Barth, O.M.; Sattler, A.; de Almeida-Muradian, L.B. Impact of origin on bioactive compounds and nutritional composition of bee pollen from southern Brazil: A screening study. Food Res. Int. 2015, 77, 82-91. [CrossRef]

68. Sattler, J.A.G.; De-Melo, A.A.M.; Nascimento, K.S.D.; Melo, I.L.P.D.; Mancini-Filho, J.; Sattler, A.; Almeida-Muradian, L.B.D. Essential minerals and inorganic contaminants (barium, cadmium, lithium, lead and vanadium) in dried bee pollen produced in Rio Grande do Sul State, Brazil. Food Sci. Technol. 2016, 36, 505-509. [CrossRef]

69. Zhang, Y.; Yang, F.; Jamali, M.A.; Peng, Z. Antioxidant Enzyme Activities and Lipid Oxidation in Rape (Brassica campestris L.) Bee Pollen Added to Salami during Processing. Molecules 2016, 21, 1439. [CrossRef]

70. Denisow, B.; Denisow-Pietrzyk, M. Biological and therapeutic properties of bee pollen: A review. J. Sci. Food Agric. 2016, 96, 4303-4309. [CrossRef]

71. Nassar, A.M.K.; Salim, Y.M.M.; Eid, K.S.A.; Shaheen, H.M.; Saati, A.A.; Hetta, H.F.; Elmistekawy, A.; Batiha, G.E. Ameliorative Effects of Honey, Propolis, Pollen, and Royal Jelly Mixture against Chronic Toxicity of Sumithion Insecticide in White Albino Rats. Molecules 2020, 25, 2633. [CrossRef] [PubMed]

72. Pavel, C.I.; Mărghitaş, L.A.; Dezmirean, D.S.; Tomoş, L.I.; Bonta, V.; Şapcaliu, A.; Buttstedt, A. Comparison between local and commercial royal jelly-Use of antioxidant activity and 10-hydroxy-2-decenoic acid as quality parameter. J. Apic. Res. 2014, 53, 116-123. [CrossRef]

73. Ab Hamid, N.; Abu Bakar, A.B.; Mat Zain, A.A.; Nik Hussain, N.H.; Othman, Z.A.; Zakaria, Z.; Mohamed, M. Composition of Royal Jelly (RJ) and Its Anti-Androgenic Effect on Reproductive Parameters in a Polycystic Ovarian Syndrome (PCOS) Animal Model. Antioxidants 2020, 9, 499. [CrossRef]

74. El-Guendouz, S.; Machado, A.M.; Aazza, S.; Lyoussi, B.; Miguel, M.G.; Mateus, M.C.; Figueiredo, A.C. Chemical Characterization and Biological Properties of Royal Jelly Samples From the Mediterranean Area. Nat. Prod. Commun. 2020, 15, 8080. [CrossRef]

75. Wang, Y.; Ma, L.; Zhang, W.; Cui, X.; Wang, H.; Xu, B. Comparison of the nutrient composition of royal jelly and worker jelly of honey bees (Apis mellifera). Apidologie 2016, 47, 48-56. [CrossRef]

76. Ramadan, M.F.; Al-Ghamdi, A. Bioactive compounds and health-promoting properties of royal jelly: A review. J. Funct. Foods 2012, 4, 39-52. [CrossRef]

77. Kanelis, D.; Tananaki, C.; Liolios, V.; Dimou, M.; Goras, G.; Rodopoulou, M.A.; Karazafiris, E.; Thrasyvoulou, A. A suggestion for royal jelly specifications. Arh. Hig. Rada Toksikol. 2015, 66, 275-284. [CrossRef]

78. Kolayli, S.; Sahin, H.; Can, Z.; Yildiz, O.; Malkoc, M.; Asadov, A. A Member of Complementary Medicinal Food: Anatolian Royal Jellies, Their Chemical Compositions, and Antioxidant Properties. J. Evid. Based Complement. Altern. Med. 2016, 21, Np43-NP48. [CrossRef]

79. Maghsoudlou, A.; Mahoonak, A.S.; Mohebodini, H.; Toldra, F. Royal Jelly: Chemistry, Storage and Bioactivities. J. Apic. Sci. 2019, 63, 17-40. [CrossRef]

80. Ahmad, S.; Campos, M.G.; Fratini, F.; Altaye, S.Z.; Li, J. New Insights into the Biological and Pharmaceutical Properties of Royal Jelly. Int. J. Mol. Sci. 2020, 21, 382. [CrossRef]

81. Park, M.J.; Kim, B.Y.; Park, H.G.; Deng, Y.; Yoon, H.J.; Choi, Y.S.; Lee, K.S.; Jin, B.R. Major royal jelly protein 2 acts as an antimicrobial agent and antioxidant in royal jelly. J. Asia-Pac. Entomol. 2019, 22, 684-689. [CrossRef]

82. Petelin, A.; Kenig, S.; Kopinč, R.; Deželak, M.; Černelič Bizjak, M.; Jenko Pražnikar, Z. Effects of Royal Jelly Administration on Lipid Profile, Satiety, Inflammation, and Antioxidant Capacity in Asymptomatic Overweight Adults. Evid. Based Complement. Altern. Med. 2019, 2019, 4969720. [CrossRef]

83. Ghanbari, E.; Nejati, V.; Khazaei, M. Antioxidant and protective effects of Royal jelly on histopathological changes in testis of diabetic rats. Int. J. Reprod. Biomed. 2016, 14, 519-526. [CrossRef]

84. Dranca, F.; Ursachi, F.; Oroian, M. Bee Bread: Physicochemical Characterization and Phenolic Content Extraction Optimization. Foods 2020, 9, 1358. [CrossRef] [PubMed] 
85. Kieliszek, M.; Piwowarek, K.; Kot, A.M.; Błażejak, S.; Chlebowska-Śmigiel, A.; Wolska, I. Pollen and bee bread as new healthoriented products: A review. Trends Food Sci. Technol. 2018, 71, 170-180. [CrossRef]

86. Khalifa, S.A.M.; Elashal, M.; Kieliszek, M.; Ghazala, N.E.; Farag, M.A.; Saeed, A.; Xiao, J.; Zou, X.; Khatib, A.; Göransson, U.; et al. Recent insights into chemical and pharmacological studies of bee bread. Trends Food Sci. Technol. 2020, 97, 300-316. [CrossRef]

87. Mayda, N.; Özkök, A.; Ecem Bayram, N.; Gerçek, Y.C.; Sorkun, K. Bee bread and bee pollen of different plant sources: Determination of phenolic content, antioxidant activity, fatty acid and element profiles. J. Food Meas. Charact. 2020, 14, 1795-1809. [CrossRef]

88. Kaplan, M.; Karaoglu, Ö.; Eroglu, N.; Silici, S. Fatty Acid and Proximate Composition of Bee Bread. Food Technol. Biotechnol. 2016, 54, 497-504. [CrossRef] [PubMed]

89. Sobral, F.; Calhelha, R.C.; Barros, L.; Dueñas, M.; Tomás, A.; Santos-Buelga, C.; Vilas-Boas, M.; Ferreira, I.C. Flavonoid Composition and Antitumor Activity of Bee Bread Collected in Northeast Portugal. Molecules 2017, 22, 248. [CrossRef]

90. Bakour, M.; Al-Waili, N.S.; El Menyiy, N.; Imtara, H.; Figuira, A.C.; Al-Waili, T.; Lyoussi, B. Antioxidant activity and protective effect of bee bread (honey and pollen) in aluminum-induced anemia, elevation of inflammatory makers and hepato-renal toxicity. J. Food Sci. Technol. 2017, 54, 4205-4212. [CrossRef]

91. Kaškonienè, V.; Adaškevičiūtè, V.; Kaškonas, P.; Mickienè, R.; Maruška, A. Antimicrobial and antioxidant activities of natural and fermented bee pollen. Food Biosci. 2020, 34, 100532. [CrossRef]

92. Pucca, M.B.; Cerni, F.A.; Oliveira, I.S.; Jenkins, T.P.; Argemí, L.; Sørensen, C.V.; Ahmadi, S.; Barbosa, J.E.; Laustsen, A.H. Bee Updated: Current Knowledge on Bee Venom and Bee Envenoming Therapy. Front. Immunol. 2019, 10. [CrossRef] [PubMed]

93. Elieh Ali Komi, D.; Shafaghat, F.; Zwiener, R.D. Immunology of Bee Venom. Clin. Rev. Allergy Immunol. 2018, 54, 386-396. [CrossRef] [PubMed]

94. Carpena, M.; Nuñez-Estevez, B.; Soria-Lopez, A.; Simal-Gandara, J. Bee Venom: An Updating Review of Its Bioactive Molecules and Its Health Applications. Nutrients 2020, 12, 3360. [CrossRef]

95. Lee, K.S.; Kim, B.Y.; Yoon, H.J.; Choi, Y.S.; Jin, B.R. Secapin, a bee venom peptide, exhibits anti-fibrinolytic, anti-elastolytic, and anti-microbial activities. Dev. Comp. Immunol. 2016, 63, 27-35. [CrossRef]

96. Mohamed, W.A.; Abd-Elhakim, Y.M.; Ismail, S.A.A. Involvement of the anti-inflammatory, anti-apoptotic, and anti-secretory activity of bee venom in its therapeutic effects on acetylsalicylic acid-induced gastric ulceration in rats. Toxicology 2019, 419, 11-23. [CrossRef]

97. Zhang, S.; Liu, Y.; Ye, Y.; Wang, X.R.; Lin, L.T.; Xiao, L.Y.; Zhou, P.; Shi, G.X.; Liu, C.Z. Bee venom therapy: Potential mechanisms and therapeutic applications. Toxicon 2018, 148, 64-73. [CrossRef]

98. Sawczuk, R.; Karpinska, J.; Miltyk, W. What do we need to know about drone brood homogenate and what is known. J. Ethnopharmacol. 2019, 245, 111581. [CrossRef] [PubMed]

99. Sidor, E.; Dżugan, M. Drone Brood Homogenate as Natural Remedy for Treating Health Care Problem: A Scientific and Practical Approach. Molecules 2020, 25, 5699. [CrossRef] [PubMed]

100. Imtara, H.; Kmail, A.; Touzani, S.; Khader, M.; Hamarshi, H.; Saad, B.; Lyoussi, B. Chemical analysis and cytotoxic and cytostatic effects of twelve honey samples collected from different regions in morocco and palestine. Evid. Based Complement. Altern. Med. 2019, 2019, 1-11. [CrossRef]

101. Portokalakis, I.; Yusof, H.I.M.; Ghanotakis, D.F.; Nigam, P.S.; Owusu-Apenten, R. Manuka honey-induced cytotoxicity against MCF7 breast cancer cells is correlated to total phenol content and antioxidant power. J. Adv. Biol. Biotechnol. 2016, 1-10. [CrossRef]

102. Aryappalli, P.; Al-Qubaisi, S.S.; Attoub, S.; George, J.A.; Arafat, K.; Ramadi, K.B.; Mohamed, Y.A.; Al-Dhaheri, M.M.; Al-Sbiei, A.; Fernandez-Cabezudo, M.J. The IL-6/STAT3 signaling pathway is an early target of manuka honey-induced suppression of human breast cancer cells. Front. Oncol. 2017, 7, 167. [CrossRef] [PubMed]

103. Henderson, K.; Aldhirgham, T.; Nigam, P.S.-N.; Owusu-Apenten, R.K. Evaluation of Manuka honey estrogen activity using the MCF-7 cell proliferation assay. J. Adv. Biol. Biotechnol. 2016, 10, 1-11. [CrossRef]

104. Aumeeruddy, M.Z.; Aumeeruddy-Elalfi, Z.; Neetoo, H.; Zengin, G.; van Staden, A.B.; Fibrich, B.; Lambrechts, I.A.; Rademan, S.; Szuman, K.M.; Lall, N. Pharmacological activities, chemical profile, and physicochemical properties of raw and commercial honey. Biocatal. Agric. Biotechnol. 2019, 18, 101005. [CrossRef]

105. Salleh, M.A.M.; Eshak, Z.; Ismail, W.I.W. Acacia honey induces apoptosis in human breast adenocarcinoma cell lines (MCF-7). J. Teknol. 2017, 79, 9-16. [CrossRef]

106. Kaya, B.; Yıldırım, A. Determination of the antioxidant, antimicrobial and anticancer properties of the honey phenolic extract of five different regions of Bingöl province. J. Food Sci. Technol. 2021, 58, 2420-2430. [CrossRef]

107. Waheed, M.; Hussain, M.B.; Javed, A.; Mushtaq, Z.; Hassan, S.; Shariati, M.A.; Khan, M.U.; Majeed, M.; Nigam, M.; Mishra, A.P. Honey and cancer: A mechanistic review. Clin. Nutr. 2019, 38, 2499-2503. [CrossRef]

108. da Silva, P.M.; Gauche, C.; Gonzaga, L.V.; Costa, A.C.O.; Fett, R. Honey: Chemical composition, stability and authenticity. Food Chem. 2016, 196, 309-323. [CrossRef]

109. Machado De-Melo, A.A.; Almeida-Muradian, L.B.d.; Sancho, M.T.; Pascual-Maté, A. Composition and properties of Apis mellifera honey: A review. J. Apic. Res. 2018, 57, 5-37. [CrossRef]

110. Biluca, F.C.; da Silva, B.; Caon, T.; Mohr, E.T.B.; Vieira, G.N.; Gonzaga, L.V.; Vitali, L.; Micke, G.; Fett, R.; Dalmarco, E.M. Investigation of phenolic compounds, antioxidant and anti-inflammatory activities in stingless bee honey (Meliponinae). Food Res. Int. 2020, 129, 108756. [CrossRef] [PubMed] 
111. Beretta, G.; Moretti, R.M.; Nasti, R.; Cincinelli, R.; Dallavalle, S.; Marelli, M.M. Apoptosis-mediated anticancer activity in prostate cancer cells of a chestnut honey (Castanea sativa L.) quinoline-pyrrolidine gamma-lactam alkaloid. Amino Acids 2021, 53, 869-880. [CrossRef]

112. Fauzi, A.N.; Yaacob, N.S. Cell cycle and apoptosis pathway modulation by Tualang honey in ER-dependent and -independent breast cancer cell lines. J. Apic. Res. 2016, 55, 366-374. [CrossRef]

113. Demir, S.; Aliyazicioglu, Y.; Turan, I.; Misir, S.; Mentese, A.; Yaman, S.O.; Akbulut, K.; Kilinc, K.; Deger, O. Antiproliferative and proapoptotic activity of Turkish propolis on human lung cancer cell line. Nutr. Cancer 2016, 68, 165-172. [CrossRef]

114. Elnakady, Y.A.; Rushdi, A.I.; Franke, R.; Abutaha, N.; Ebaid, H.; Baabbad, M.; Omar, M.O.M.; Al Ghamdi, A.A. Characteristics, chemical compositions and biological activities of propolis from Al-Bahah, Saudi Arabia. Sci. Rep. 2017, 7, 1-13. [CrossRef] [PubMed]

115. Noureddine, H.; Hage-Sleiman, R.; Wehbi, B.; Fayyad-Kazan, H.; Hayar, S.; Traboulssi, M.; Alyamani, O.A.; Faour, W.H.; ElMakhour, Y. Chemical characterization and cytotoxic activity evaluation of Lebanese propolis. Biomed. Pharmacother. 2017, 95, 298-307. [CrossRef] [PubMed]

116. Czyżewska, U.; Siemionow, K.; Zaręba, I.; Miltyk, W. Proapoptotic activity of propolis and their components on human tongue squamous cell carcinoma cell line (CAL-27). PLoS ONE 2016, 11, e0157091. [CrossRef]

117. Touzani, S.; Embaslat, W.; Imtara, H.; Kmail, A.; Kadan, S.; Zaid, H.; ElArabi, I.; Badiaa, L.; Saad, B. In vitro evaluation of the potential use of propolis as a multitarget therapeutic product: Physicochemical properties, chemical composition, and immunomodulatory, antibacterial, and anticancer properties. BioMed Res. Int. 2019, 2019, 1-11. [CrossRef] [PubMed]

118. Celińska-Janowicz, K.; Zaręba, I.; Lazarek, U.; Teul, J.; Tomczyk, M.; Pałka, J.; Miltyk, W. Constituents of propolis: Chrysin, caffeic acid, $p$-coumaric acid, and ferulic acid induce PRODH/POX-dependent apoptosis in human tongue squamous cell carcinoma cell (CAL-27). Front. Pharmacol. 2018, 9, 336. [CrossRef]

119. Sun, L.; Guo, Y.; Zhang, Y.; Zhuang, Y. Antioxidant and anti-tyrosinase activities of phenolic extracts from rape bee pollen and inhibitory melanogenesis by cAMP/MITF/TYR pathway in B16 mouse melanoma cells. Front. Pharmacol. 2017, 8, 104. [CrossRef]

120. Zou, Y.; Hu, J.; Huang, W.; Zhu, L.; Shao, M.; Dordoe, C.; Ahn, Y.-J.; Wang, D.; Zhao, Y.; Xiong, Y. The botanical origin and antioxidant, anti-BACE1 and antiproliferative properties of bee pollen from different regions of South Korea. BMC Complement. Med. Ther. 2020, 20, 236. [CrossRef] [PubMed]

121. Saisavoey, T.; Sangtanoo, P.; Srimongkol, P.; Reamtong, O.; Karnchanatat, A. Hydrolysates from bee pollen could induced apoptosis in human bronchogenic carcinoma cells (ChaGo-K-1). J. Food Sci. Technol. 2021, 58, 752-763. [CrossRef]

122. Liu, C.-C.; Hao, D.-J.; Zhang, Q.; An, J.; Zhao, J.-J.; Chen, B.; Zhang, L.-L.; Yang, H. Application of bee venom and its main constituent melittin for cancer treatment. Cancer Chemother. Pharmacol. 2016, 78, 1113-1130. [CrossRef] [PubMed]

123. Moga, M.A.; Dimienescu, O.G.; Arvătescu, C.A.; Ifteni, P.; Pleş, L. Anticancer activity of toxins from bee and snake venom-An overview on ovarian cancer. Molecules 2018, 23, 692. [CrossRef]

124. Sangboonruang, S.; Kitidee, K.; Chantawannakul, P.; Tragoolpua, K.; Tragoolpua, Y. Melittin from Apis florea Venom as a Promising Anticancer Agent. Antibiotics 2020, 9, 517. [CrossRef] [PubMed]

125. Plasay, M.; Wahid, S.; Natzir, R.; Miskad, U.A. Selective cytotoxicity Assay in anticancer drug of Melittin Isolated from Bee Venom (Apis cerana indica) to several human cell lines: HeLa, WiDr and Vero. J. Chem. Pharm. Sci 2016, 9, 2674-2676.

126. Zolfagharian, H.; Khalilifard Borojeni, S.; Babaie, M. Evaluation of anticancer effects induced by Apis mellifera venom on breast cancer cell line. Alborz Univ. Med. J. 2020, 9, 357-366.

127. Mahmoodzadeh, A.; Zarrinnahad, H.; Bagheri, K.P.; Moradia, A.; Shahbazzadeh, D. First report on the isolation of melittin from Iranian honey bee venom and evaluation of its toxicity on gastric cancer AGS cells. J. Chin. Med. Assoc. 2015, 78, 574-583. [CrossRef]

128. Hou, K.K.; Pan, H.; Lanza, G.M.; Wickline, S.A. Melittin derived peptides for nanoparticle based siRNA transfection. Biomaterials 2013, 34, 3110-3119. [CrossRef]

129. Yu, X.; Dai, Y.; Zhao, Y.; Qi, S.; Liu, L.; Lu, L.; Luo, Q.; Zhang, Z. Melittin-lipid nanoparticles target to lymph nodes and elicit a systemic anti-tumor immune response. Nat. Commun. 2020, 11, 1-14. [CrossRef]

130. Holle, L.; Song, W.; Holle, E.; Wei, Y.; Wagner, T.; Yu, X. A matrix metalloproteinase 2 cleavable melittin/avidin conjugate specifically targets tumor cells in vitro and in vivo. Int. J. Oncol. 2003, 22, 93-98. [CrossRef] [PubMed]

131. Su, M.; Chang, W.; Zhang, K.; Cui, M.; Wu, S.; Xu, T. Expression and purification of recombinant ATF-mellitin, a new type fusion protein targeting ovarian cancer cells, in P. pastoris. Oncol. Rep. 2016, 35, 1179-1185. [CrossRef] [PubMed]

132. Zhang, S.; Shao, Q.; Geng, H.; Su, S. The effect of royal jelly on the growth of breast cancer in mice. Oncol. Lett. 2017, 14, 7615-7621. [CrossRef]

133. Miyata, Y.; Sakai, H. Anti-cancer and protective effects of royal jelly for therapy-induced toxicities in malignancies. Int. J. Mol. Sci. 2018, 19, 3270. [CrossRef] [PubMed]

134. Filipič, B.; Gradišnik, L.; Rihar, K.; Šooš, E.; Pereyra, A.; Potokar, J. The influence of royal jelly and human interferon-alpha (HuIFN- $\alpha \mathrm{N} 3$ ) on proliferation, glutathione level and lipid peroxidation in human colorectal adenocarcinoma cells in vitro. Arh. Za Hig. Rada I Toksikol. 2015, 66. [CrossRef]

135. Miyata, Y.; Ohba, K.; Matsuo, T.; Mitsunari, K.; Sakai, H. A randomized, double-blinded clinical trial of royal jelly intake for anticancer effects and suppressing adverse events in renal cell carcinoma patients treated with tyrosine kinase inhibitors. J. Clin. Oncol. 2020, 38, 697. [CrossRef] 
136. Araki, K.; Miyata, Y.; Ohba, K.; Nakamura, Y.; Matsuo, T.; Mochizuki, Y.; Sakai, H. Oral intake of royal jelly has protective effects against tyrosine kinase inhibitor-induced toxicity in patients with renal cell carcinoma: A randomized, double-blinded, placebo-controlled trial. Medicines 2019, 6, 2. [CrossRef]

137. Osama, H.; Abdullah, A.; Gamal, B.; Emad, D.; Sayed, D.; Hussein, E.; Mahfouz, E.; Tharwat, J.; Sayed, S.; Medhat, S. Effect of honey and royal jelly against cisplatin-induced nephrotoxicity in patients with cancer. J. Am. Coll. Nutr. 2017, 36, 342-346. [CrossRef]

138. Wang, S.-Y.; Chen, C.-W. Effects of royal jelly extracts on growth inhibition, differentiation human leukemic U937 cells and its immunomodulatory activity. Biocell 2019, 43, 29-41.

139. Elsayed, N.; El-Din, H.S.; Altemimi, A.B.; Ahmed, H.Y.; Pratap-Singh, A.; Abedelmaksoud, T.G. In Vitro Antimicrobial, Antioxidant and Anticancer Activities of Egyptian Citrus Beebread. Molecules 2021, 26, 2433. [CrossRef] [PubMed]

140. Aru, B.; Güzelmeric, E.; Akgül, A.; Demirel, G.Y.; Kırmızıbekmez, H. Antiproliferative activity of chemically characterized propolis from Turkey and its mechanisms of action. Chem. Biodivers. 2019, 16, e1900189. [CrossRef]

141. Emran, T.B.; Uddin, M.M.N.; Rahman, M.A.; Uddin, M.Z.; Islam, M.M. Phytochemical, antimicrobial, cytotoxic, analgesic and anti-inflammatory properties of Azadirachta indica: A therapeutic study. J. Bioanal. Biomed. 2015, S12, 1-7. [CrossRef]

142. Udaondo, Z.; Matilla, M.A. Mining for novel antibiotics in the age of antimicrobial resistance. Microb. Biotechnol. 2020, 13, 1702-1704. [CrossRef] [PubMed]

143. Peraman, R.; Sure, S.K.; Dusthackeer, V.N.A.; Chilamakuru, N.B.; Yiragamreddy, P.R.; Pokuri, C.; Kutagulla, V.K.; Chinni, S. Insights on recent approaches in drug discovery strategies and untapped drug targets against drug resistance. Future J. Pharm. Sci. 2021, 7, 56. [CrossRef]

144. Sartini, S.; Permana, A.D.; Mitra, S.; Tareq, A.M.; Salim, E.; Ahmad, I.; Harapan, H.; Emran, T.B.; Nainu, F. Current State and Promising Opportunities on Pharmaceutical Approaches in the Treatment of Polymicrobial Diseases. Pathogens 2021, 10, 245. [CrossRef]

145. Didaras, N.A.; Karatasou, K.; Dimitriou, T.G.; Amoutzias, G.D.; Mossialos, D. Antimicrobial Activity of Bee-Collected Pollen and Beebread: State of the Art and Future Perspectives. Antibiotics 2020, 9, 811. [CrossRef]

146. Combarros-Fuertes, P.; Fresno, J.M.; Estevinho, M.M.; Sousa-Pimenta, M.; Tornadijo, M.E.; Estevinho, L.M. Honey: Another Alternative in the Fight against Antibiotic-Resistant Bacteria? Antibiotics 2020, 9, 774. [CrossRef]

147. Nolan, V.C.; Harrison, J.; Wright, J.E.E.; Cox, J.A.G. Clinical Significance of Manuka and Medical-Grade Honey for AntibioticResistant Infections: A Systematic Review. Antibiotics 2020, 9, 766. [CrossRef]

148. Uddin, M.Z.; Rana, M.S.; Hossain, S.; Dutta, E.; Ferdous, S.; Dutta, M.; Emran, T.B. In vivo neuroprotective, antinociceptive, anti-inflammatory potential in Swiss albino mice and in vitro antioxidant and clot lysis activities of fractionated Holigarna longifolia Roxb. bark extract. J. Complement. Integr. Med. 2019, 17, 1-10. [CrossRef]

149. Bucekova, M.; Jardekova, L.; Juricova, V.; Bugarova, V.; Di Marco, G.; Gismondi, A.; Leonardi, D.; Farkasovska, J.; Godocikova, J.; Laho, M.; et al. Antibacterial Activity of Different Blossom Honeys: New Findings. Molecules 2019, 24, 1573. [CrossRef] [PubMed]

150. El Sohaimy, S.A.; Masry, S.H.D.; Shehata, M.G. Physicochemical characteristics of honey from different origins. Ann. Agric. Sci. 2015, 60, 279-287. [CrossRef]

151. Silici, S.; Sagdic, O.; Ekici, L. Total phenolic content, antiradical, antioxidant and antimicrobial activities of Rhododendron honeys. Food Chem. 2010, 121, 238-243. [CrossRef]

152. Almasaudi, S. The antibacterial activities of honey. Saudi J. Biol. Sci. 2021, 28, 2188-2196. [CrossRef] [PubMed]

153. Al-Hatamleh, M.A.I.; Hatmal, M.M.M.; Sattar, K.; Ahmad, S.; Mustafa, M.Z.; Bittencourt, M.D.C.; Mohamud, R. Antiviral and Immunomodulatory Effects of Phytochemicals from Honey against COVID-19: Potential Mechanisms of Action and Future Directions. Molecules 2020, 25, 5017. [CrossRef]

154. Hadagali, M.D.; Chua, L.S. The anti-inflammatory and wound healing properties of honey. Eur. Food Res. Technol. 2014, 239, 1003-1014. [CrossRef]

155. Hazrati, M.; Mehrabani, D.; Japoni, A.; Montasery, H.; Azarpira, N.; Hamidian-shirazi, A.R.; Tanideh, N. Effect of Honey on Healing of Pseudomonas aeruginosa Infected Burn Wounds in Rat. J. Appl. Anim. Res. 2010, 37, 161-165. [CrossRef]

156. Lusby, P.E.; Coombes, A.L.; Wilkinson, J.M. Bactericidal Activity of Different Honeys against Pathogenic Bacteria. Arch. Med. Res. 2005, 36, 464-467. [CrossRef]

157. Hossain, K.S.; Hossain, M.G.; Moni, A.; Rahman, M.M.; Rahman, U.H.; Alam, M.; Kundu, S.; Rahman, M.M.; Hannan, M.A.; Uddin, M.J. Prospects of honey in fighting against COVID-19: Pharmacological insights and therapeutic promises. Heliyon 2020, 6, e05798. [CrossRef]

158. Shahzad, A.; Cohrs, R.J. In vitro antiviral activity of honey against varicella zoster virus (VZV): A translational medicine study for potential remedy for shingles. Transl. Biomed. 2012, 3. [CrossRef]

159. Zeina, B.; Othman, O.; al-Assad, S. Effect of honey versus thyme on Rubella virus survival in vitro. J. Altern Complement. Med. 1996, 2, 345-348. [CrossRef]

160. Hashemipour, M.A.; Tavakolineghad, Z.; Arabzadeh, S.A.M.; Iranmanesh, Z.; Nassab, S.A.H.G. Antiviral Activities of Honey, Royal Jelly, and Acyclovir Against HSV-1. Wounds 2014, 26, 47-54.

161. Al-Waili, N.S.; Al-Waili, T.N.; Al-Waili, A.N.; Saloom, K.S. Influence of Natural Honey on Biochemical and Hematological Variables in AIDS: A case study. Sci. World J. 2006, 6, 389430. [CrossRef] [PubMed] 
162. Socarras, K.M.; Theophilus, P.A.S.; Torres, J.P.; Gupta, K.; Sapi, E. Antimicrobial Activity of Bee Venom and Melittin against Borrelia burgdorferi. Antibiotics 2017, 6, 31. [CrossRef]

163. Sforcin, J.M.; Bankova, V. Propolis: Is there a potential for the development of new drugs? J. Ethnopharmacol. 2011, 133, 253-260. [CrossRef] [PubMed]

164. Veiga, R.S.; De Mendonça, S.; Mendes, P.B.; Paulino, N.; Mimica, M.J.; Lagareiro Netto, A.A.; Lira, I.S.; López, B.G.-C.; Negrão, V.; Marcucci, M.C. Artepillin C and phenolic compounds responsible for antimicrobial and antioxidant activity of green propolis and Baccharis dracunculifolia DC. J. Appl. Microbiol. 2017, 122, 911-920. [CrossRef]

165. Yoshimasu, Y.; Ikeda, T.; Sakai, N.; Yagi, A.; Hirayama, S.; Morinaga, Y.; Furukawa, S.; Nakao, R. Rapid Bactericidal Action of Propolis against Porphyromonas gingivalis. J. Dent. Res. 2018, 97, 928-936. [CrossRef] [PubMed]

166. Veloz, J.J.; Alvear, M.; Salazar, L.A. Antimicrobial and Antibiofilm Activity against Streptococcus mutans of Individual and Mixtures of the Main Polyphenolic Compounds Found in Chilean Propolis. BioMed Res. Int. 2019, 2019, 7602343. [CrossRef]

167. Seibert, J.B.; Bautista-Silva, J.P.; Amparo, T.R.; Petit, A.; Pervier, P.; dos Santos Almeida, J.C.; Azevedo, M.C.; Silveira, B.M.; Brandão, G.C.; de Souza, G.H.B.; et al. Development of propolis nanoemulsion with antioxidant and antimicrobial activity for use as a potential natural preservative. Food Chem. 2019, 287, 61-67. [CrossRef] [PubMed]

168. Ali, A.M.; Kunugi, H. Propolis, Bee Honey, and Their Components Protect against Coronavirus Disease 2019 (COVID-19): A Review of In Silico, In Vitro, and Clinical Studies. Molecules 2021, 26, 1232. [CrossRef]

169. Bridi, R.; Atala, E.; Pizarro, P.N.; Montenegro, G. Honeybee Pollen Load: Phenolic Composition and Antimicrobial Activity and Antioxidant Capacity. J. Nat. Prod. 2019, 82, 559-565. [CrossRef] [PubMed]

170. Kacániová, M.; Vuković, N.; Chlebo, R.; Haščík, P.; Rovna, K.; Cubon, J.; Džugan, M.; Pasternakiewicz, A. The antimicrobial activity of honey, bee pollen loads and beeswax from Slovakia. Arch. Biol. Sci. 2012, 64, 927-934. [CrossRef]

171. Graikou, K.; Kapeta, S.; Aligiannis, N.; Sotiroudis, G.; Chondrogianni, N.; Gonos, E.; Chinou, I. Chemical analysis of Greek pollen-Antioxidant, antimicrobial and proteasome activation properties. Chem. Cent. J. 2011, 5, 33. [CrossRef]

172. Morais, M.; Moreira, L.; Feás, X.; Estevinho, L.M. Honeybee-collected pollen from five Portuguese Natural Parks: Palynological origin, phenolic content, antioxidant properties and antimicrobial activity. Food Chem. Toxicol. 2011, 49, 1096-1101. [CrossRef] [PubMed]

173. Pascoal, A.; Rodrigues, S.; Teixeira, A.; Feás, X.; Estevinho, L.M. Biological activities of commercial bee pollens: Antimicrobial, antimutagenic, antioxidant and anti-inflammatory. Food Chem. Toxicol. 2014, 63, 233-239. [CrossRef]

174. Fatrcová-Šramková, K.; Nôžková, J.; Kačániová, M.; Máriássyová, M.; Rovná, K.; Stričík, M. Antioxidant and antimicrobial properties of monofloral bee pollen. J. Environ. Sci. Health Part B 2013, 48, 133-138. [CrossRef] [PubMed]

175. AbdElsalam, E.; Foda, H.S.; Abdel-Aziz, M.S.; Abd, F.K. Antioxidant and Antimicrobial activities of Egyptian Bee Pollen. Middle East. J. Appl. Sci. 2018, 8, 1248-1255.

176. Tareq, A.M.; Farhad, S.; Uddin, A.N.; Hoque, M.; Nasrin, M.S.; Uddin, M.M.R.; Hasan, M.; Sultana, A.; Munira, M.S.; Lyzu, C.; et al. Chemical profiles, pharmacological properties, and in silico studies provide new insights on Cycas pectinata. Heliyon 2020, 6 , e04061. [CrossRef] [PubMed]

177. Talukder, M.E.U.; Aklima, J.; Emran, T.B.; Islam, S.; Rahman, A.; Bhuiyan, R.H. In vitro antioxidant potential of Momordica charantia fruits extracts. J. Pharm. Res. 2013, 3, 963-971. [CrossRef]

178. McCloskey, M.C.; Shaheen, S.; Rabago, L.; Hulverson, M.A.; Choi, R.; Barrett, L.K.; Arnold, S.L.M. Evaluation of in vitro and in vivo antibiotic efficacy against a novel bioluminescent Shigella flexneri. Sci. Rep. 2019, 9, 13567. [CrossRef] [PubMed]

179. Dash, R.; Ahsan, M.T.; Hosen, S.M.Z.; Rahman, M.G.; Emran, T.B.; Uddin, M.M.N. Evolution of selective COX-2 inhibitor from Alangium salvifolium: An in silico approach. J. Appl. Pharm. Sci. 2015, 5, 89-93. [CrossRef]

180. Sukarsih, Y.; Arfiansyah, R.; Roska, T.P.; Murdifin, M.; Kasim, S.; Nainu, F. Protective Effect of Ethanol Extract of Legundi (Vitex trifolia L.) Leaves against Staphylococcus aureus in Drosophila Infection Model. Biointerface Res. Appl. Chem. 2021, 11, 13989-13996.

181. Anisa, A.N.; Rahmasari, M.; Roska, T.P.; Arfiansyah, R.; Sartini, S.; Djide, M.N.; Harapan, H.; Nainu, F. Antimicrobial Effect of Roselle (Hibiscus sabdariffa L.) Water Fraction against Pseudomonas aeruginosa using Drosophila Infection Model. Biointerface Res. Appl. Chem. 2021, 11, 12877-12885.

182. Nainu, F.; Djide, M.N.; Subehan, S.; Sartini, S.; Roska, T.P.; Salim, E.; Kuraishi, T. Protective Signatures of Roselle (Hibiscus sabdariffa L.) Calyx Fractions against Staphylococcus aureus in Drosophila Infection Model. HAYATI J. Biosci. 2020, 27, 306-313.

183. Ahsan, M.; Gonsales, A.V.; Sartini, S.; Wahyudin, E.; Nainu, F. In vivo anti-staphylococcal activity of roselle (Hibiscus sabdariffa L.) calyx extract in Drosophila model of infection. J. Herbmed. Pharmacol. 2019, 8, 41-46. [CrossRef]

184. Nainu, F.; Asri, R.M.; Djide, M.N.; Ahsan, M.; Arfiansyah, R.; Sartini, S.; Alam, G. Protective effect of green algae Ulva reticulata against Pseudomonas aeruginosa in Drosophila infection model. HAYATI J. Biosci. 2019, 26, 163-171.

185. Nainu, F.; Asri, R.M.; Arsyad, A.; Manggau, M.A.; Amir, M.N. In vivo antibacterial activity of green algae Ulva reticulata against Staphylococcus aureus in Drosophila model of infection. Pharmacogn. J. 2018, 10, 993-997. [CrossRef]

186. Wu, W.; Li, R.; Li, X.; He, J.; Jiang, S.; Liu, S.; Yang, J. Quercetin as an Antiviral Agent Inhibits Influenza A Virus (IAV) Entry. Viruses 2016, 8, 6. [CrossRef]

187. Al Naggar, Y.; Giesy, J.P.; Abdel-Daim, M.M.; Javed Ansari, M.; Al-Kahtani, S.N.; Yahya, G. Fighting against the second wave of COVID-19: Can honeybee products help protect against the pandemic? Saudi J. Biol. Sci. 2021, 28, 1519-1527. [CrossRef]

188. Cokcetin, N.N.; Pappalardo, M.; Campbell, L.T.; Brooks, P.; Carter, D.A.; Blair, S.E.; Harry, E.J. The Antibacterial Activity of Australian Leptospermum Honey Correlates with Methylglyoxal Levels. PLoS ONE 2016, 11, e0167780. [CrossRef] [PubMed] 
189. Stagos, D.; Soulitsiotis, N.; Tsadila, C.; Papaeconomou, S.; Arvanitis, C.; Ntontos, A.; Karkanta, F.; Adamou-Androulaki, S.; Petrotos, K.; Spandidos, D.A.; et al. Antibacterial and antioxidant activity of different types of honey derived from Mount Olympus in Greece. Int. J. Mol. Med. 2018, 42, 726-734. [CrossRef] [PubMed]

190. Das, A.; Datta, S.; Mukherjee, S.; Bose, S.; Ghosh, S.; Dhar, P. Evaluation of antioxidative, antibacterial and probiotic growth stimulatory activities of Sesamum indicum honey containing phenolic compounds and lignans. LWT Food Sci. Technol. 2015, 61, 244-250. [CrossRef]

191. Almasaudi, S.B.; Al-Nahari, A.A.M.; Abd El-Ghany, E.S.M.; Barbour, E.; Al Muhayawi, S.M.; Al-Jaouni, S.; Azhar, E.; Qari, M.; Qari, Y.A.; Harakeh, S. Antimicrobial effect of different types of honey on Staphylococcus aureus. Saudi J. Biol. Sci. 2017, 24, 1255-1261. [CrossRef] [PubMed]

192. Morroni, G.; Alvarez-Suarez, J.M.; Brenciani, A.; Simoni, S.; Fioriti, S.; Pugnaloni, A.; Giampieri, F.; Mazzoni, L.; Gasparrini, M.; Marini, E.; et al. Comparison of the Antimicrobial Activities of Four Honeys From Three Countries (New Zealand, Cuba, and Kenya). Front. Microbiol. 2018, 9. [CrossRef]

193. Junie, L.; Vica, M.; Mirel, G.; Matei, H. Physico-chemical characterization and antibacterial activity of different types of honey tested on strains isolated from hospitalized patients. J. Apic. Sci. 2016, 60, 5-18. [CrossRef]

194. Massaro, C.F.; Simpson, J.B.; Powell, D.; Brooks, P. Chemical composition and antimicrobial activity of honeybee (Apis mellifera ligustica) propolis from subtropical eastern Australia. Sci. Nat. 2015, 102, 68. [CrossRef]

195. Bittencourt, M.L.F.; Ribeiro, P.R.; Franco, R.L.P.; Hilhorst, H.W.M.; de Castro, R.D.; Fernandez, L.G. Metabolite profiling, antioxidant and antibacterial activities of Brazilian propolis: Use of correlation and multivariate analyses to identify potential bioactive compounds. Food Res. Int. 2015, 76, 449-457. [CrossRef]

196. Campos, J.F.; Santos, U.P.D.; Rocha, P.D.S.D.; Damião, M.J.; Balestieri, J.B.P.; Cardoso, C.A.L.; Paredes-Gamero, E.J.; Estevinho, L.M.; de Picoli Souza, K.; Santos, E.L.D. Antimicrobial, Antioxidant, Anti-Inflammatory, and Cytotoxic Activities of Propolis from the Stingless Bee Tetragonisca fiebrigi (Jataí). Evid. Based Complement. Altern. Med. 2015, 2015, 296186. [CrossRef]

197. Regueira, M.S.; Tintino, S.R.; da Silva, A.R.P.; Costa, M.d.S.; Boligon, A.A.; Matias, E.F.F.; de Queiroz Balbino, V.; Menezes, I.R.A.; Melo Coutinho, H.D. Seasonal variation of Brazilian red propolis: Antibacterial activity, synergistic effect and phytochemical screening. Food Chem. Toxicol. 2017, 107, 572-580. [CrossRef]

198. Barua, N.; Aziz, M.A.I.; Tareq, A.M.; Sayeed, M.A.; Alam, N.; ul Alam, N.; Uddin, M.A.; Lyzu, C.; Emran, T.B. In vivo and in vitro evaluation of pharmacological activities of Adenia trilobata (Roxb.). Biochem. Biophys. Rep. 2020, 23, 100772. [CrossRef] [PubMed]

199. Nina, N.; Quispe, C.; Jiménez-Aspee, F.; Theoduloz, C.; Feresín, G.E.; Lima, B.; Leiva, E.; Schmeda-Hirschmann, G. Antibacterial Activity, Antioxidant Effect and Chemical Composition of Propolis from the Región del Maule, Central Chile. Molecules 2015, 20, 18144-18167. [CrossRef]

200. AL-Ani, I.; Zimmermann, S.; Reichling, J.; Wink, M. Antimicrobial Activities of European Propolis Collected from Various Geographic Origins Alone and in Combination with Antibiotics. Medicines 2018, 5, 2. [CrossRef] [PubMed]

201. De Marco, S.; Piccioni, M.; Pagiotti, R.; Pietrella, D. Antibiofilm and Antioxidant Activity of Propolis and Bud Poplar Resins versus Pseudomonas aeruginosa. Evid. Based Complement. Altern. Med. 2017, 2017, 5163575. [CrossRef]

202. Rakib, A.; Ahmed, S.; Islam, M.A.; Uddin, M.M.N.; Paul, A.; Chy, M.N.U.; Emran, T.B.; Seidel, V. Pharmacological studies on the antinociceptive, anxiolytic and antidepressant activity of Tinospora crispa. Phytother. Res. 2020, 34, 2978-2984. [CrossRef] [PubMed]

203. Popova, M.; Giannopoulou, E.; Skalicka-Woźniak, K.; Graikou, K.; Widelski, J.; Bankova, V.; Kalofonos, H.; Sivolapenko, G.; Gaweł-Bęben, K.; Antosiewicz, B.; et al. Characterization and Biological Evaluation of Propolis from Poland. Molecules 2017, 22, 1159. [CrossRef] [PubMed]

204. Chen, Y.-W.; Ye, S.-R.; Ting, C.; Yu, Y.-H. Antibacterial activity of propolins from Taiwanese green propolis. J. Food Drug Anal. 2018, 26, 761-768. [CrossRef] [PubMed]

205. Atsalakis, E.; Chinou, I.; Makropoulou, M.; Karabournioti, S.; Graikou, K. Evaluation of Phenolic Compounds in Cistus creticus Bee Pollen from Greece. Antioxidant and Antimicrobial Properties. Nat. Prod. Commun. 2017, 12, 1141. [CrossRef]

206. Akhir, R.A.M.; Bakar, M.F.A.; Sanusi, S.B. Antioxidant and antimicrobial activity of stingless bee bread and propolis extracts. AIP Conf. Proc. 2017, 1891, 020090. [CrossRef]

207. Rahman, J.; Tareq, A.M.; Hossain, M.M.; Sakib, S.A.; Islam, M.N.; Uddin, A.B.M.N.; Hoque, M.; Nasrin, M.S.; Ali, M.H.; Caiazzo, E.; et al. Biological evaluation, DFT calculations and molecular docking studies on the antidepressant and cytotoxicity activities of Cycas pectinata Buch.-Ham. Compounds. Pharmaceuticals 2020, 13, 232. [CrossRef]

208. Coutinho, D.; Karibasappa, S.; Mehta, D. Royal Jelly Antimicrobial Activity against Periodontopathic Bacteria. J. Interdiscip. Dent. 2018, 8, 18-22. [CrossRef]

209. Susilowati, H.; Murakami, K.; Yumoto, H.; Amoh, T.; Hirao, K.; Hirota, K.; Matsuo, T.; Miyake, Y. Royal Jelly Inhibits Pseudomonas aeruginosa Adherence and Reduces Excessive Inflammatory Responses in Human Epithelial Cells. BioMed Res. Int. 2017, 2017, 3191752. [CrossRef] [PubMed]

210. Bakour, M.; Fernandes, Â.; Barros, L.; Sokovic, M.; Ferreira, I.C.F.R.; Badiaa, 1. Bee bread as a functional product: Chemical composition and bioactive properties. LWT 2019, 109, 276-282. [CrossRef]

211. Ivanišová, E.; Kačániová, M.; Frančáková, H.; Petrová, J.; Hutková, J.; Brovarskyi, V.; Velychko, S.; Adamchuk, L.; Schubertová, Z.; Musilová, J. Bee bread-Perspective source of bioactive compounds for future. Potravin. Slovak J. Food Sci. 2015, 9, 592-598. [CrossRef] 
212. Marques Pereira, A.F.; Albano, M.; Bérgamo Alves, F.C.; Murbach Teles Andrade, B.F.; Furlanetto, A.; Mores Rall, V.L.; Delazari dos Santos, L.; de Oliveira Orsi, R.; Fernandes Júnior, A. Influence of apitoxin and melittin from Apis mellifera bee on Staphylococcus aureus strains. Microb. Pathog. 2020, 141, 104011. [CrossRef]

213. Haktanir, I.; Masoura, M.; Mantzouridou, F.T.; Gkatzionis, K. Mechanism of antimicrobial activity of honeybee (Apis mellifera) venom on Gram-negative bacteria: Escherichia coli and Pseudomonas spp. AMB Express 2021, 11, 54. [CrossRef] [PubMed]

214. Lamas, A.; Arteaga, V.; Regal, P.; Vázquez, B.; Miranda, J.M.; Cepeda, A.; Franco, C.M. Antimicrobial Activity of Five Apitoxins from Apis mellifera on Two Common Foodborne Pathogens. Antibiotics 2020, 9, 367. [CrossRef]

215. Sunyoto, T.; Verdonck, K.; El Safi, S.; Potet, J.; Picado, A.; Boelaert, M. Uncharted territory of the epidemiological burden of cutaneous leishmaniasis in sub-Saharan Africa-A systematic review. PLoS Negl. Trop. Dis. 2018, 12, e0006914. [CrossRef]

216. Bristy, T.A.; Barua, N.; Tareq, A.M.; Sakib, S.A.; Etu, S.T.; Chowdhury, K.H.; Jyoti, M.A.; Aziz, M.A.I.; Reza, A.S.M.A.; Caiazzo, E.; et al. Deciphering the pharmacological properties of methanol extract of Psychotria calocarpa leaves by in vivo, in vitro and in silico approaches. Pharmaceuticals 2020, 13, 183. [CrossRef]

217. Tzani, M.; Barrasa, A.; Vakali, A.; Georgakopoulou, T.; Mellou, K.; Pervanidou, D. Surveillance data for human leishmaniasis indicate the need for a sustainable action plan for its management and control, Greece, 2004 to 2018. Eurosurveillance 2021, 26, 2000159. [CrossRef]

218. Sundar, S.; Chakravarty, J. Leishmaniasis: An update of current pharmacotherapy. Expert Opin. Pharmacother. 2013, 14, 53-63. [CrossRef] [PubMed]

219. Sangshetti, J.N.; Khan, F.A.K.; Kulkarni, A.A.; Arote, R.; Patil, R.H. Antileishmanial drug discovery: Comprehensive review of the last 10 years. RSC Adv. 2015, 5, 32376-32415. [CrossRef]

220. Alvar, J.; Arana, B. Leishmaniasis, Impact and Therapeutic Needs. In Drug Discovery for Leishmaniasis; Rivas, L., Gil, C., Eds.; Royal Society of Chemistry: London, UK, 2017.

221. Cauich-Kumul, R.; Campos, M.R.S. Bee Propolis: Properties, Chemical Composition, Applications, and Potential Health Effects. In Bioactive Compounds; Elsevier: Amsterdam, The Netherlands, 2019; pp. 227-243.

222. El-Guendouz, S.; Lyoussi, B.; Miguel, M.G. Insight on propolis from mediterranean countries: Chemical composition, biological activities and application fields. Chem. Biodivers. 2019, 16, e1900094. [CrossRef]

223. Siheri, W.; Zhang, T.; Ebiloma, G.U.; Biddau, M.; Woods, N.; Hussain, M.Y.; Clements, C.J.; Fearnley, J.; Ebel, R.E.; Paget, T. Chemical and antimicrobial profiling of propolis from different regions within Libya. PLoS ONE 2016, 11, e0155355. [CrossRef]

224. Omar, R.; Igoli, J.O.; Zhang, T.; Gray, A.I.; Ebiloma, G.U.; Clements, C.J.; Fearnley, J.; Ebel, R.E.; Paget, T.; De Koning, H.P. The chemical characterization of Nigerian propolis samples and their activity against Trypanosoma brucei. Sci. Rep. 2017, 7, 1-10. [CrossRef]

225. Alotaibi, A.; Ebiloma, G.U.; Williams, R.; Alenezi, S.; Donachie, A.-M.; Guillaume, S.; Igoli, J.O.; Fearnley, J.; De Koning, H.P.; Watson, D.G. European propolis is highly active against trypanosomatids including Crithidia fasciculata. Sci. Rep. 2019, 9, 1-10. [CrossRef] [PubMed]

226. Tareq, A.M.; Sohel, M.; Uddin, M.; Mahmud, M.H.; Hoque, M.; Reza, A.A.; Nasrin, M.S.; Kader, F.B.; Emran, T.B. Possible neuropharmacological effects of Apis cerana indica beehive in the Swiss Albino mice. J. Adv. Biotechnol. Exp. Ther. 2020, 3, 128-134. [CrossRef]

227. da Silveira Regueira-Neto, M.; Tintino, S.R.; Rolón, M.; Coronal, C.; Vega, M.C.; de Queiroz Balbino, V.; de Melo Coutinho, H.D. Antitrypanosomal, antileishmanial and cytotoxic activities of Brazilian red propolis and plant resin of Dalbergia ecastaphyllum (L) Taub. Food Chem. Toxicol. 2018, 119, 215-221. [CrossRef]

228. Silici, S.; Kutluca, S. Chemical composition and antibacterial activity of propolis collected by three different races of honeybees in the same region. J. Ethnopharmacol. 2005, 99, 69-73. [CrossRef]

229. Silva, M.P.; Silva, T.M.; Mengarda, A.C.; Salvadori, M.C.; Teixeira, F.S.; Alencar, S.M.; Luz Filho, G.C.; Bueno-Silva, B.; de Moraes, J. Brazilian red propolis exhibits antiparasitic properties in vitro and reduces worm burden and egg production in an mouse model harboring either early or chronic Schistosoma mansoni infection. J. Ethnopharmacol. 2021, 264, 113387. [CrossRef]

230. Rebouças-Silva, J.; Celes, F.S.; Lima, J.B.; Barud, H.S.; de Oliveira, C.I.; Berretta, A.A.; Borges, V.M. Parasite killing of Leishmania (V) braziliensis by standardized propolis extracts. Evid. Based Complement. Altern. Med. 2017, 2017, 1-14. [CrossRef]

231. Devequi-Nunes, D.; Machado, B.A.S.; Barreto, G.d.A.; Rebouças Silva, J.; da Silva, D.F.; da Rocha, J.L.C.; Brandão, H.N.; Borges, V.M.; Umsza-Guez, M.A. Chemical characterization and biological activity of six different extracts of propolis through conventional methods and supercritical extraction. PLoS ONE 2018, 13, e0207676. [CrossRef]

232. Santiago de Sousa, A.R.; Cruz de Moraes, S.Z.; Barbosa Viana-Júnior, A.; Divino de Araujo, E. Toward a Novel Pharmacology and Therapeutic Understanding of Brazilian Propolis: A Meta-Analytical Approach. Pharmacogn. Rev. 2020, 14, 1-7. [CrossRef]

233. Dutra, R.P.; Bezerra, J.L.; da Silva, M.C.P.; Batista, M.C.A.; Patrício, F.J.B.; Nascimento, F.R.F.; Ribeiro, M.N.S.; Guerra, R.N.M. Antileishmanial activity and chemical composition from Brazilian geopropolis produced by stingless bee Melipona fasciculata. Rev. Bras. De Farmacogn. 2019, 29, 287-293. [CrossRef]

234. Gomes, A.N.P.; Camara, C.A.; dos Santos Sousa, A.; dos Santos, F.d.A.R.; de Santana Filho, P.C.; Dorneles, G.P.; Romão, P.R.T.; Silva, T.M.S. Chemical Composition of Bee Pollen and Leishmanicidal Activity of Rhusflavone. Rev. Bras. De Farmacogn. 2021, 31, 176-183. [CrossRef] 
235. Cuesta-Rubio, O.; Fernández, M.C.; Hernández, I.M.; Jaramillo, C.G.J.; González, V.H.; Porto, R.M.D.O.; Delange, D.M.; Fidalgo, L.M.; Piccinelli, A.L.; Campone, L. Chemical profile and anti-leishmanial activity of three Ecuadorian propolis samples from Quito, Guayaquil and Cotacachi regions. Fitoterapia 2017, 120, 177-183. [CrossRef]

236. Cunha, B.C.; De Miranda, M.B.; Afonso, L.C.C.; Abreu, S.R.L.; Da Silva, G.R.; Testasicca, M.C.S.; Moura, S.A.L. Brazilian green propolis hydroalcoholic extract as a therapeutic adjuvant to treat cutaneous leishmaniasis. J. Appl. Pharm. Sci. 2020, 10, 124-132

237. Emran, T.B.; Mowla, T.-E.; Ahmed, S.; Zahan, S.; Rakib, A.; Hasan, M.S.; Amin, M.N.; Mow, T.R.; Uddin, M.M.N. Sedative, anxiolytic, antinociceptive, anti-inflammatory and antipyretic effects of a chloroform extract from the leaves of Urena sinuata (Borss) L. in rodents. J. Appl. Life Sci. Int. 2018, 16, 1-19. [CrossRef]

238. de Miranda, M.B.; Lanna, M.F.; Nascimento, A.L.B.; de Paula, C.A.; de Souza, M.E.; Felipetto, M.; da Silva Barcelos, L.; de Moura, S.A.L. Hydroalcoholic extract of Brazilian green propolis modulates inflammatory process in mice submitted to a low protein diet. Biomed. Pharmacother. 2019, 109, 610-620. [CrossRef] [PubMed]

239. dos Santos Thomazelli, A.P.F.; Tomiotto-Pellissier, F.; da Silva, S.S.; Panis, C.; Orsini, T.M.; Cataneo, A.H.D.; Miranda-Sapla, M.M.; Custódio, L.A.; Tatakihara, V.L.H.; Bordignon, J. Brazilian propolis promotes immunomodulation on human cells from American Tegumentar Leishmaniasis patients and healthy donors infected with L. braziliensis. Cell. Immunol. 2017, 311, 22-27. [CrossRef]

240. Yesmin, S.; Paul, A.; Naz, T.; Rahman, A.B.M.A.; Akhter, S.F.; Wahed, M.I.I.; Emran, T.B.; Siddiqui, S.A. Membrane stabilization as a mechanism of the anti-inflammatory activity of ethanolic root extract of Choi (Piper chaba). Clin. Phytosci. 2020, 6, 59. [CrossRef]

241. Hegazi, A.G.; Al Guthami, F.M.; Al Gethami, A.F.; El Fadaly, H.A. Beneficial Effects of Capparis spinosa Honey on the Immune Response of Rats Infected with Toxoplasma gondii. J. Pharmacopunct. 2017, 20, 112-118. [CrossRef]

242. Menna-Barreto, R.F.S.; Salomão, K.; Dantas, A.P.; Santa-Rita, R.M.; Soares, M.J.; Barbosa, H.S.; de Castro, S.L. Different cell death pathways induced by drugs in Trypanosoma cruzi: An ultrastructural study. Micron 2009, 40, 157-168. [CrossRef]

243. Araujo, J.M.E.; Mendonça-Melo, L.S.; Araujo, E.D.; Fernandes, R.P.M.; Scher, R. Phenolic composition and leishmanicidal activity of red propolis and Dalbergia ecastaphyllum (L.) Taub (Fabaceae) Extracts from Sergipe, Brazil. Braz. Arch. Biol. Technol. 2018, 61. [CrossRef]

244. Arruda, C.; Ribeiro, V.P.; Mejía, J.A.A.; Almeida, M.O.; Goulart, M.O.; Candido, A.C.B.B.; dos Santos, R.A.; Magalhães, L.G.; Martins, C.H.G.; Bastos, J.K. Green propolis: Cytotoxic and leishmanicidal activities of artepillin C, p-coumaric acid, and their degradation products. Rev. Bras. De Farmacogn. 2020, 30, 169. [CrossRef]

245. Mohamed, A.H.; El-Nabi, S.E.H.; Bayomi, A.E.; Abdelaal, A.A. Effect of bee venom or proplis on molecular and parasitological aspects of Schistosoma mansoni infected mice. J. Parasit. Dis. 2016, 40, 390-400. [CrossRef]

246. Hassan, S.E.; Abou-El-Dobal, S.K.; Hegazi, A.G. Bioassay of Egyptian propolis on Toxocara vitulorum adult worms. World Appl.Sci.J. 2016, 34, 283-289.

247. Mokhtar, A.B.; El-Gayar, E.K.; Habib, E.S. In vitro anti-protozoal activity of propolis extract and cysteine proteases inhibitor (phenyl vinyl sulfone) on Blastocystis species. J. Egypt. Soc. Parasitol. 2016, 46, 261-272. [CrossRef] [PubMed]

248. Soufy, H.; Nadia, M.; Nasr, S.M.; Abd El-Aziz, T.H.; Khalil, F.A.M.; Ahmed, Y.F.; Abou Zeina, H.A.A. Effect of Egyptian propolis on cryptosporidiosis in immunosuppressed rats with special emphasis on oocysts shedding, leukogram, protein profile and ileum histopathology. Asian Pac. J. Trop. Med. 2017, 10, 253-262. [CrossRef] [PubMed]

249. Hegazi, A.G.; Al Guthami, F.M.; Al Gethami, A.F.; Barakat, A.M. Egyptian propolis 12: Influence of Propolis on Cytokines of Toxoplasma gondii Infected Rats. Int. J. Curr. Microbiol. Appl. Sci. 2017, 6, 202-211. [CrossRef]

250. Al-Ghandour, A.M.F.; Ahmed, H.K.; Salem, A.E.; Tealeb, A.-S.M.; Mohamed, R.M.S.M.; Yousef, A.M. Efficacy of olibanum and propolis medicinal extracts versus metronidazole in Giardia lamblia experimentally infected mice. Microbes Infect. Dis. 2020, 1, 209-220. [CrossRef]

251. Alanazi, S.; Alenzi, N.; Alenazi, F.; Tabassum, H.; Watson, D. Chemical characterization of Saudi propolis and its antiparasitic and anticancer properties. Sci. Rep. 2021, 11,1-9.

252. Afrouzan, H.; Zakeri, S.; Mehrizi, A.A.; Molasalehi, S.; Tahghighi, A.; Shokrgozar, M.A.; Es-Haghi, A.; Djadid, N.D. Antiplasmodial assessment of four different Iranian propolis extracts. Arch. Iran. Med. 2017, 20, 270-281.

253. Tavakoli, P.; Shaddel, M.; Yakhchali, M.; Raoufi, N.; Shamsi, H.; Dastgheib, M. Antileishmanial effects of propolis against Leishmania major in vitro and in vivo. Ann. Mil. Health Sci. Res. 2020, 18, e100630. [CrossRef]

254. Deghbar, N.; Mezioug, D.; Kahina, T.; Medjdoub, Y.-M.; Touil-Boukoffa, C. Antihydatic and immunomodulatory effects of Algerian propolis ethanolic extract: In vitro and in vivo study. Asian Pac. J. Trop. Med. 2019, 12, 106.

255. Nina, N.; Lima, B.; Feresin, G.E.; Giménez, A.; Salamanca Capusiri, E.; Schmeda-Hirschmann, G. Antibacterial and leishmanicidal activity of Bolivian propolis. Lett. Appl. Microbiol. 2016, 62, 290-296. [CrossRef]

256. Omar, R.M.K.; Igoli, J.; Gray, A.I.; Ebiloma, G.U.; Clements, C.; Fearnley, J.; Edrada Ebel, R.A.; Zhang, T.; De Koning, H.P.; Watson, D.G. Chemical characterisation of Nigerian red propolis and its biological activity against Trypanosoma brucei. Phytochem. Anal. 2016, 27, 107-115. [CrossRef] [PubMed]

257. Alenezi, S.S.; Natto, M.J.; Igoli, J.O.; Gray, A.I.; Fearnley, J.; Fearnley, H.; de Koning, H.P.; Watson, D.G. Novel flavanones with anti-trypanosomal activity isolated from Zambian and Tanzanian propolis samples. Int. J. Parasitol. Drugs Drug Resist. 2020, 14, 201-207. [CrossRef] [PubMed]

258. Marin, S.; Vlasceanu, G.M.; Tiplea, R.E.; Bucur, I.R.; Lemnaru, M.; Marin, M.M.; Grumezescu, A.M. Applications and toxicity of silver nanoparticles: A recent review. Curr Top. Med. Chem 2015, 15, 1596-1604. [CrossRef] 
259. Al-Yousef, H.M.; Amina, M.; Alqahtani, A.S.; Alqahtani, M.S.; Malik, A.; Hatshan, M.R.; Siddiqui, M.R.H.; Khan, M.; Shaik, M.R.; Ola, M.S.; et al. Pollen Bee Aqueous Extract-Based Synthesis of Silver Nanoparticles and Evaluation of Their Anti-Cancer and Anti-Bacterial Activities. Processes 2020, 8, 524. [CrossRef]

260. El-Guendouz, S.; Lyoussi, B.; Lourenço, J.P.; Rosa da Costa, A.M.; Miguel, M.G.; Barrocas Dias, C.; Manhita, A.; Jordao, L.; Nogueira, I.; Faleiro, M.L. Magnetite nanoparticles functionalized with propolis against methicillin resistant strains of Staphylococcus aureus. J. Taiwan Inst. Chem. Eng. 2019, 102, 25-33. [CrossRef]

261. Chen, X.; Liu, B.; Li, X.; An, T.T.; Zhou, Y.; Li, G.; Wu-Smart, J.; Alvarez, S.; Naldrett, M.J.; Eudy, J.; et al. Identification of anti-inflammatory vesicle-like nanoparticles in honey. J. Extracell Vesicles 2021, 10, e12069. [CrossRef] [PubMed]

262. Iadnut, A.; Mamoon, K.; Thammasit, P.; Pawichai, S.; Tima, S.; Preechasuth, K.; Kaewkod, T.; Tragoolpua, Y.; Tragoolpua, K. In Vitro Antifungal and Antivirulence Activities of Biologically Synthesized Ethanolic Extract of Propolis-Loaded PLGA Nanoparticles against Candida albicans. Evid. Based Complement. Altern. Med 2019, 2019, 3715481. [CrossRef] [PubMed]

263. do Nascimento, T.G.; da Silva, P.F.; Azevedo, L.F.; da Rocha, L.G.; de Moraes Porto, I.C.; Lima, E.M.T.F.; Basílio-Júnior, I.D.; Grillo, L.A.; Dornelas, C.B.; Fonseca, E.J.; et al. Polymeric Nanoparticles of Brazilian Red Propolis Extract: Preparation, Characterization, Antioxidant and Leishmanicidal Activity. Nanoscale Res. Lett 2016, 11, 301. [CrossRef]

264. Saber, A.E.S.; Abdelwahab, A.K.; Amir, A.M.E.; Nassar, M.I.; Zohdi, H.F. Bee venom loaded chitosan nanoparticles as treatment for amoebiasis in mice. J. Egypt. Soc. Parasitol. 2017, 47, 443-458. [CrossRef] 